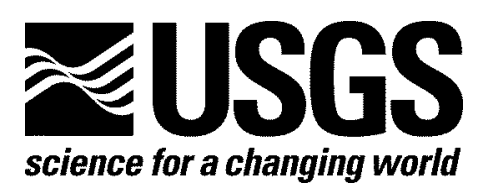

\title{
Mercury at the Oat Hill Extension Mine and James Creek, Napa County, California: Tailings, Sediment, Water, and Biota, 2003-2004
}

By Aaron J. Slowey, ${ }^{1}$ James J. Rytuba, ${ }^{2}$ Roger L. Hothem, ${ }^{3}$ and Jason T. May ${ }^{4}$

2007

Open File Report 2007-1132

\footnotetext{
${ }^{1}$ Research Chemist, Geology Discipline, 345 Middlefield Rd, MS 901, Menlo Park, California 94025; aslowey@usgs.gov; 650 329-5474.

2 Research Geologist, Geology Discipline, jrytuba@usgs.gov

${ }^{3}$ Research Wildlife Biologist, Biology Discipline, roger_hothem@usgs.gov

${ }^{4}$ Aquatic Ecologist, Water Resources Discipline, jasonmay@usgs.gov
}

\section{U.S. Department of the Interior U.S. Geological Survey}




\title{
U.S. Department of the Interior DIRK KEMPTHORNE, Secretary
}

\section{U.S. Geological Survey Mark D. Myers, Director}

\author{
U.S. Geological Survey, Menlo Park, California 2007
}

For product and ordering information:

World Wide Web: http://www.usgs.gov/pubprod

Telephone: 1-888-ASK-USGS

For more information on the USGS - the Federal source for science about the Earth, its natural and living resources, natural hazards, and the environment:

World Wide Web: http://www.usgs.gov

Telephone: 1-888-ASK-USGS

Suggested citation:

Slowey, A.J., Rytuba, J.J., Hothem, R.L., May, J.T., 2001, Mercury at the Oat Hill Extension Mine and James Creek, Napa County, California: Tailings, sediment, water, and biota, 2003-2004: U.S. Geological Survey Open-File Report 2007-1132, 60 p.

[http://pubs.usgs.gov/of/2007/1132/]

Any use of trade, product, or firm names is for descriptive purposes only and does not imply endorsement by the U.S. Government.

Although this report is in the public domain, permission must be secured from the individual copyright owners to reproduce any copyrighted material contained within this report. 


\section{Contents}

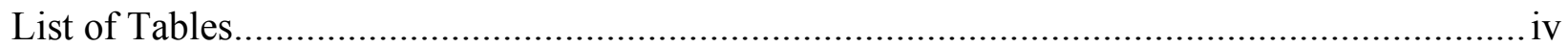

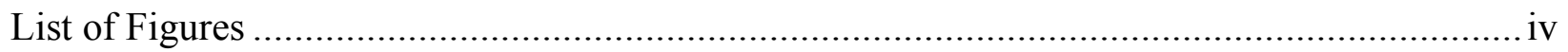

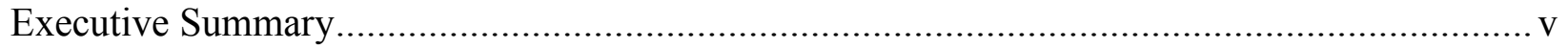

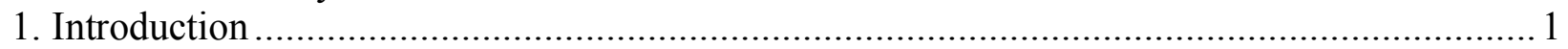

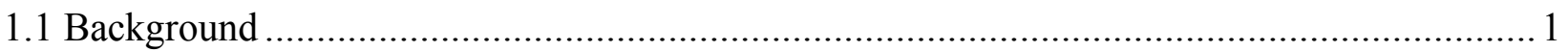

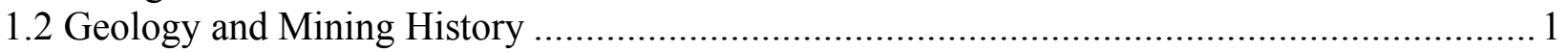

1.3 Transport and biogeochemistry of mercury in mine waste-contaminated sediments ............... 2

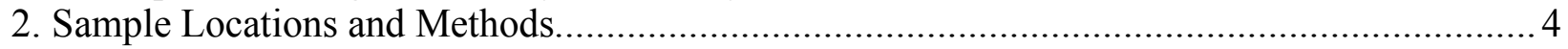

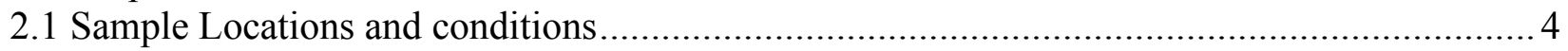

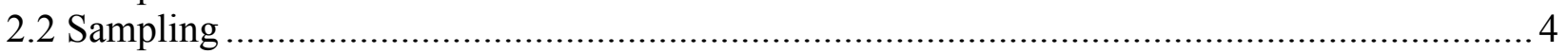

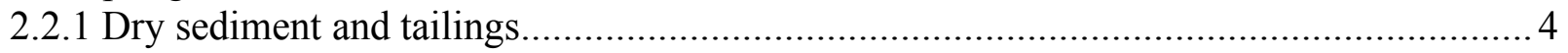

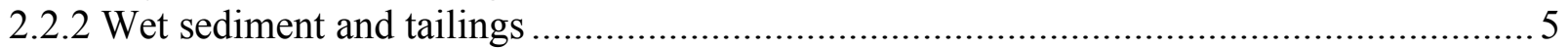

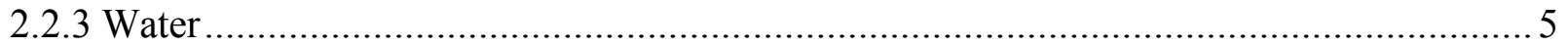

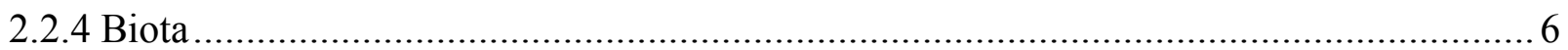

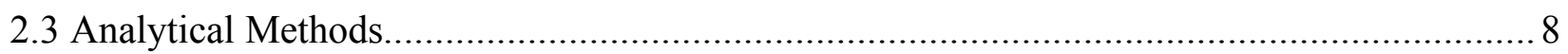

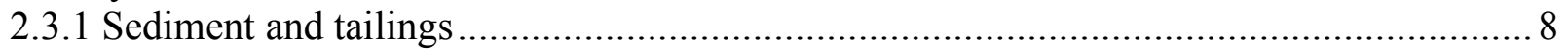

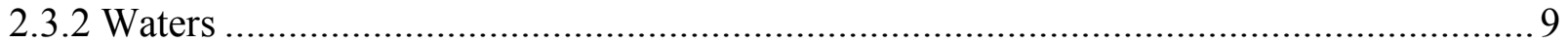

2.3.3 Biota

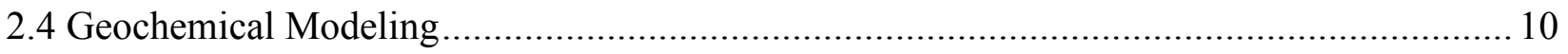

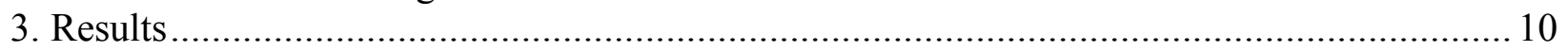

3.1 Tailings and Dry Sediment at OHE Mine .................................................................... 10

3.2 Water and Sediment in James Creek and the Tributary Draining the OHE Mine ................... 12

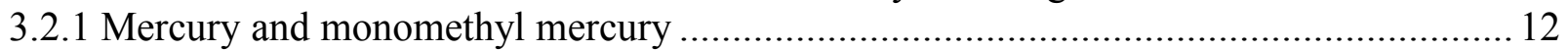

3.2.2 Geochemistry of James Creek water and OHE drainage ............................................ 17

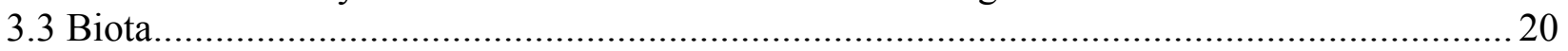

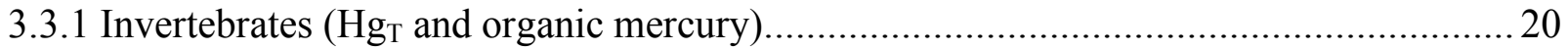

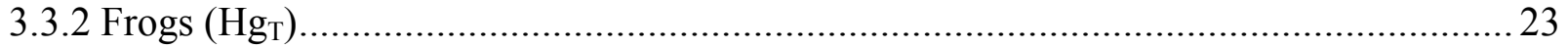

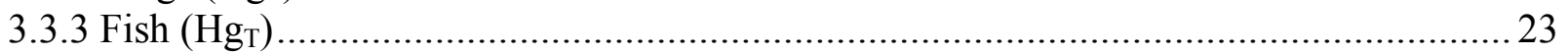

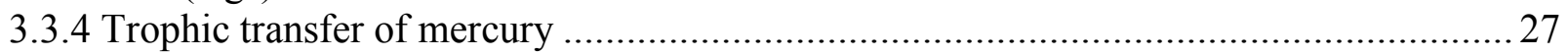

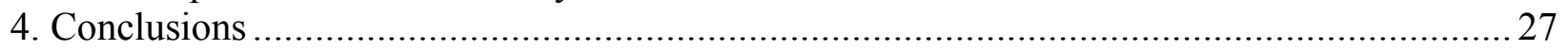

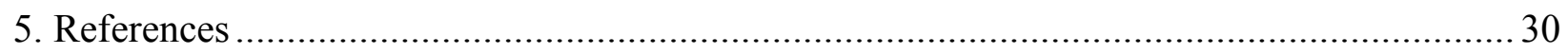

Appendix 1. Thermodynamic modeling results..................................................................... 


\section{List of Tables}

Table 1. Sample locations and descriptions. See Fig. 1 and 2 for maps illustrating these locations and their hydrological relationship. Coordinates are based on the NAD 27 datum............ 4

Table 2. Chemical analysis of tailings and sediments at the Oat Hill Extension site, and soil deemed as representing background concentrations.

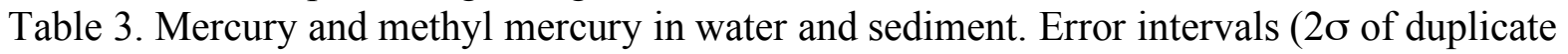
analyses, or 95 percent confidence level) are reported where they are on the order of the last significant digit.

Table 4. Temperature, $\mathrm{pH}$, alkalinity, and select anions. All concentration units are $\mathrm{mg} / \mathrm{L}$, except ionic strength, which is reported in molar units. Nitrate was not detected $(<0.2 \mathrm{mg} / \mathrm{L})$ in any sample.

Table 5. Elemental composition of filtered $(<0.45 \mu \mathrm{m})$ water. ICP-MS results. All units are $\mu \mathrm{g} / \mathrm{L}$ (microgram per liter) unless otherwise noted. Data highlighted in yellow were used to evaluate saturation indices of selected minerals (Table 7).

Table 6. Elemental composition of unfiltered water. ICP-MS results. All units are $\mu \mathrm{g} / \mathrm{L}$ (microgram per liter) unless otherwise noted. See Table 5 for detection limits of undetected elements (denoted with an "nd").

Table 7. Mineral saturation indices (S.I.) under a fixed atmospheric oxygen fugacity of 0.2 (approxmately $10 \mathrm{mg} / \mathrm{L}$ dissolved oxygen), based on the Geochemist's Workbench 'thermo.dat' database (http://www.geology.uiuc.edu/Hydrogeology/hydro_thermo.htm). .20

Table 8. Mercury and methlymercury in invertebrates collected from James Creek and the Oat Hill Extension Mine. ww = wet weight.

Table 9. Mercury concentrations in Foothill Yellow-legged frogs (Rana boylii) collected from James Creek and Oat Hill Extension Mine.

Table 10. Mercury concentrations in fish collected from James Creek on May 20, 2004......... 28

\section{List of Figures}

Figure 1. Location of Oat Hill Extension Mine and other mercury mines in the James Creek watershed. Locations of water and sediment samples taken in James Creek, Tributary 1 that drains the Oat Hill Extension Mine area, and the spring at the mine.

Figure 2. Location of sample sites of tailings and sediment at the Oat Hill Extension and water and sediment samples in James Creek and Oat Hill Extension tributary.............................36

Figure 3. Overview of tailings pile at the Oat Hill Extension. Note drainage channel containing barrels in central part of photo is shown in detail in Figure 12 .................................... 2

Figure 4. Remains of brick retort at Oat Hill Extension location of sample 23OE11............... 2 Figure 5. Historic placer mining of cinnabar using a rocker in James Creek below the Oat Hill Mine tailings.

Figure 6. James Creek location JC1 upstream of OHE drainage sampled for biota in Spring and Autumn 2004.

Figure 8. Sampling location JC2 on Tributary 1, spring 2004. The drain was dry in the Autumn sampling period, and no samples were collected...

Figure 9. Wetland area near Oat Hill Extension Mine (OHE1, Fig. 2) sampled for biota in Spring and Autumn 2004. 8 
Figure 13. James Creek at water, sediment and biota sample site 04JC1. Iron staining on rocks in creek results from precipitation of iron (hydr)oxide from the Corona and Twin Peaks mines.

Figure 14. (a) James Creek at sample site 04JC1. Sediment consists of medium to coarse sand and fine silt to clay sizes, the latter containing iron (hydr)oxides derived from Corona and Twin Peaks mine drainage. (b) Cinnabar present in panned concentrate from this location.15 Figure 15. Average methylmercury concentration ( $\mu \mathrm{g} / \mathrm{g}$, wet wt.) in larval dragonflies (Odanata) from 42 Sierra Nevada sites, 1999-2002, compared with selected water striders from the Oat Hill/James Creek study area, 2004.

Figure 16. Average methylmercury concentration $(\mu \mathrm{g} / \mathrm{g}$, wet wt.) in adult waterstriders (Gerridae) from 74 Sierra Nevada sites, 1999-2002, compared with selected water striders from the Oat Hill/James Creek study area, 2004.

Figure 17. $\log _{10}$ transforms of $\mathrm{Hg}_{\mathrm{T}}$ (ppm, wet-weight basis) in Rainbow Trout and California Roach ([Hg]) compared to $\log _{10}$ transforms of total fish body length in $\mathrm{mm}(\mathrm{L})$. See text for an explanation as to why the data were log-transformed. The results of the regression analysis includes the squared correlation coefficient $\mathrm{R}^{2}$ which denotes the proportion of variance of $\mathrm{Hg}$ accounted for by length and analysis of variance (ANOVA) significance tests in which the $F$ ratio statistic evaluates the probability that a relationship this strong could be made by chance, as is more fully explained in the text.

\section{Executive Summary}

The Oat Hill Extension (OHE) Mine is one of several mercury mines located in the James Creek/Pope Creek watershed that produced mercury from the 1870's until 1944 (U.S. Bureau of Mines, 1965). The OHE Mine developed veins and mineralized fault zones hosted in sandstone that extended eastward from the Oat Hill Mine. Waste material from the Oat Hill Mine was reprocessed at the OHE Mine using gravity separation methods to obtain cinnabar concentrates that were processed in a retort. The U.S. Bureau of Land Management requested that the U.S. Geological Survey measure and characterize mercury and other chemical constituents that are potentially relevant to ecological impairment of biota in tailings, sediment, and water at the OHE Mine and in the tributaries of James Creek that drain the mine area (termed Drainage $A$ and $B$ ) (Figs. 1 and 2). This report summarizes such data obtained from sampling of tailings and sediments at the OHE on October 17, 2003; water, sediment, and biota from James Creek on May 20, 2004; and biota on October 29, 2004. These data are interpreted to provide a preliminary assessment of the potential ecological impact of the mine on the James Creek watershed.

The mine tailings are unusual in that they have not been roasted and contain relatively high concentrations of mercury ( 400 to $1200 \mathrm{ppm}$ ) compared to unroasted waste rock at other mines. These tailings have contaminated a tributary to James Creek with mercury primarily by erosion, on the basis of higher concentration of mercury $(780 \mathrm{ng} / \mathrm{L})$ measured in unfiltered (total mercury, $\mathrm{Hg}_{\mathrm{T}}$ ) spring water flowing from the OHE to James Creek compared to 5 to $14 \mathrm{ng} / \mathrm{L} \mathrm{Hg}_{\mathrm{T}}$ measured in James Creek itself. Tailing piles (presumably from past Oat Hill mine dumping) near the USBLM property boundary and upstream of the main OHE mine drainage channel (Drainage A; Fig. 2) also likely emit mercury, on the basis of their mercury composition (930 to $1200 \mathrm{ppm})$. The OHE spring water is likely an appreciable source of sulfate and carbonate to 
James Creek, because the spring water was enriched in sulfate $(130 \mathrm{mg} / \mathrm{L})$ and carbonate (430 $\mathrm{mg} / \mathrm{L}$ as $\mathrm{CaCO}_{3}$ ) compared to James Creek water $\left(70\right.$ to $100 \mathrm{mg} / \mathrm{L} \mathrm{SO}_{4}{ }^{2-}$ and 110 to $170 \mathrm{mg} / \mathrm{L}$ as $\left.\mathrm{CaCO}_{3}\right)$ at the time of sampling. Concentrations of mercury in active channel sediment from James Creek are variable and potentially high, on the basis of chemical analysis $(2.5$ to $17 \mu \mathrm{g} / \mathrm{g}$ wet sediment) and easily visible cinnabar grains in panned concentrates.

Average (geometric mean) organic mercury (presumably monomethyl mercury (MMHg); 2.3 .3 ) concentrations in several invertebrate taxa collected from the James Creek watershed locations were higher than invertebrates taken from a Northern California location lacking a known point source of mercury. The mean proportion of MMHg to total mercury in James Creek predatory insect samples was 40 percent $(1$ standard deviation $=30$ percent $)$; only 40 percent of all insect samples had a $\mathrm{MMHg} / \mathrm{Hg}_{\mathrm{T}}$ proportion greater than 0.5 . The low proportions of $\mathrm{MMHg}$ measured in invertebrates in James Creek and the presence of cinnabar in the creek suggest that some invertebrates may have anomolously high $\mathrm{Hg}$ concentrations as a result of the injestion or adhesion of extremely fine-grained cinnabar particles.

Interpretation of $\mathrm{Hg}_{\mathrm{T}}$ in frogs and fish as an indicator of mercury reactivity, biouptake, or trophic transfer is limited, pending MMHg measuremens, by the possibility of these whole-body samples having contained cinnabar particles at the time of analysis. To minimize this limitation, the gastrointestinal tracts and external surfaces of all amphibians, where cinnabar most likely resides, were carefully flushed to remove any visible particles. However, extremely fine-grained, invisible, adhesive cinnabar particles likely exist in the amphibians' habitats.

$\mathrm{Hg}_{\mathrm{T}}$ in foothill yellow-legged frogs collected from the James Creek study area, ranging from 0.1 to $0.6 \mu \mathrm{g} / \mathrm{g} \mathrm{Hg}$, was on average twice that of an extensive database compiled from $\mathrm{Hg}_{\mathrm{T}}$ in frogs studied throughout Northern California. Average concentrations of $\mathrm{Hg}_{\mathrm{T}}$ in frogs from $\mathrm{James}$ Creek were similar upstream $(0.18 \mu \mathrm{g} / \mathrm{g})$ and downstream $(0.15 \mu \mathrm{g} / \mathrm{g})$ of the confluence with Tributary 1 and at the lower Corona Mine adit drainage $(0.14 \mu \mathrm{g} / \mathrm{g})$. Frogs may be susceptible to trophic transfer of $\mathrm{MMHg}$ from invertebrates, but further study is required to rule out cinnabar 'contamination.'

$\mathrm{Hg}_{\mathrm{T}}$ concentrations in rainbow trout collected from James Creek upstream and downstream of Tributary 1 averaged $0.10 \mu \mathrm{g} / \mathrm{g}$ and $0.13 \mu \mathrm{g} / \mathrm{g}$, respectively. Compared to invertebrates, trout $\mathrm{Hg}_{\mathrm{T}}$ was less variable, suggesting that trout were less contaminated with cinnabar. California roach had significantly higher $\mathrm{Hg}_{\mathrm{T}}$ on average than trout $(0.16 \mathrm{vs} .0 .12 \mu \mathrm{g} / \mathrm{g})$, and can be considered moderately contaminated compared to the same species from other sites in Northern California, which average $0.12 \mu \mathrm{g} / \mathrm{g} \mathrm{Hg}$.

While limited measurements of mercury in water, sediment, and fish exceed, in some samples, predefined ecologically protective criteria for mine-impacted California systems, they do not clearly demonstrate that the biota residing in James Creek in the vicinity of the OHE are ecologically impaired. The potential for ecological impairment is clearly evident from invertebrate methyl mercury results and may manifest in other biological ecosystem residents that have yet to be studied (e.g., piscivorous birds). Methyl mercury concentrations in flowing water and sediment from James Creek and the tributary that drains the OHE are relatively low, ranging from 0.04 to $0.08 \mathrm{ng} / \mathrm{L}$, although these data should be cautiously interpreted (see $\S 3.2$ ). 
While the results of this investigation suggest that the OHE contributes inorganic mercury to James Creek, they do not indicate the extent to which the OHE site is ecologically impairing biota relative to other sources of mercury. Improved sampling and analytical methods are recommended for future study. 


\section{Introduction}

\subsection{Background}

The Oat Hill Extension (OHE) Mine is one of several mercury mines in the East Mayacamas mining district that produced mercury from the early 1870s until 1944 (U.S. Bureau of Mines, 1965). This mine produced an estimated 1,000 flasks of mercury, whereas the larger neighboring Oat Hill Mine produced 165,000 flasks of mercury over a similar period. The Oat Hill and nearby Corona and Twin Peaks mercury mines are located on private land in the upper part of the James Creek watershed (Fig. 1, appended). The OHE is located on federal land managed by the U.S. Bureau of Land Management (USBLM). The USBLM requested that the U.S. Geological Survey (USGS) measure and characterize mercury and other chemical constituents in tailings, sediment, water, and biota at the OHE Mine and the tributary of James Creek that drains the mine area (Fig. 2, appended) relevant to recognizing impairment of biota. This report summarizes data obtained from sampling of tailings and sediments at the OHE on October 17, 2003; water, sediment, and biota from James Creek on May 20, 2004; and biota on October 29, 2004. These data are interpreted to provide a preliminary assessment of the potential ecological impact of the mine on the James Creek watershed.

\subsection{Geology and Mining History}

The mercury ores in the Mayacamas mining district occur in greywacke (sandstone) of the Franciscan Formation at the Oat Hill and OHE mines, and in silica-carbonate altered serpentinite at the Corona and Twin Peaks mines. The sandstone has been hydrothermally altered primarily to kaolinite and quartz in the mineralized area. Cinnabar (alpha-HgS) is the primary ore mineral and usually occurs in association with pyrite $\left(\mathrm{FeS}_{2}\right)$. Calcite and quartz veins are present in the altered sandstone and locally contain cinnabar. Elemental sulfur is present in the upper part of the Oat Hill deposit that, along with kaolinite alteration, indicates that the mercury was deposited in the steam-heated environment above the paleo-groundwater table.

Mercury ores at the OHE mine were mined from the eastern extension of veins and mineralized fault zones of the Oat Hill mine. Thus, the ore grades were likely similar at both mines, although specific information for ore grades at the OHE are not available. Ore grades at the Oat Hill mine ranged from 0.75 to 1.0 percent, with grades as high as 2 percent during the early years of mining. Because of poor mercury recovery from the ore, both the waste rock and tailings, containing as much as 0.16 percent mercury, were locally reprocessed at both the Oat Hill and OHE Mine.

Material from mine waste piles was brought from the Oat Hill mine to the OHE property and reprocessed using a trommel (rotating sieve) and concentrating tables. During this concentration process, oversized fragments from the trommel were discarded to a waste pile and undersized fragments ${ }^{1}$ were sent to a concentrating table where the cinnabar was removed, and the waste sent to a tailings pile (Fig. 3) (U.S. Bureau of Mines, 1965). Because the material was not processed in a retort or furnace, the tailings from this process are unusual. Only the cinnabar

\footnotetext{
${ }^{1}$ There is no record indicating that additional crushing occurred prior to cinnabar removal.
} 


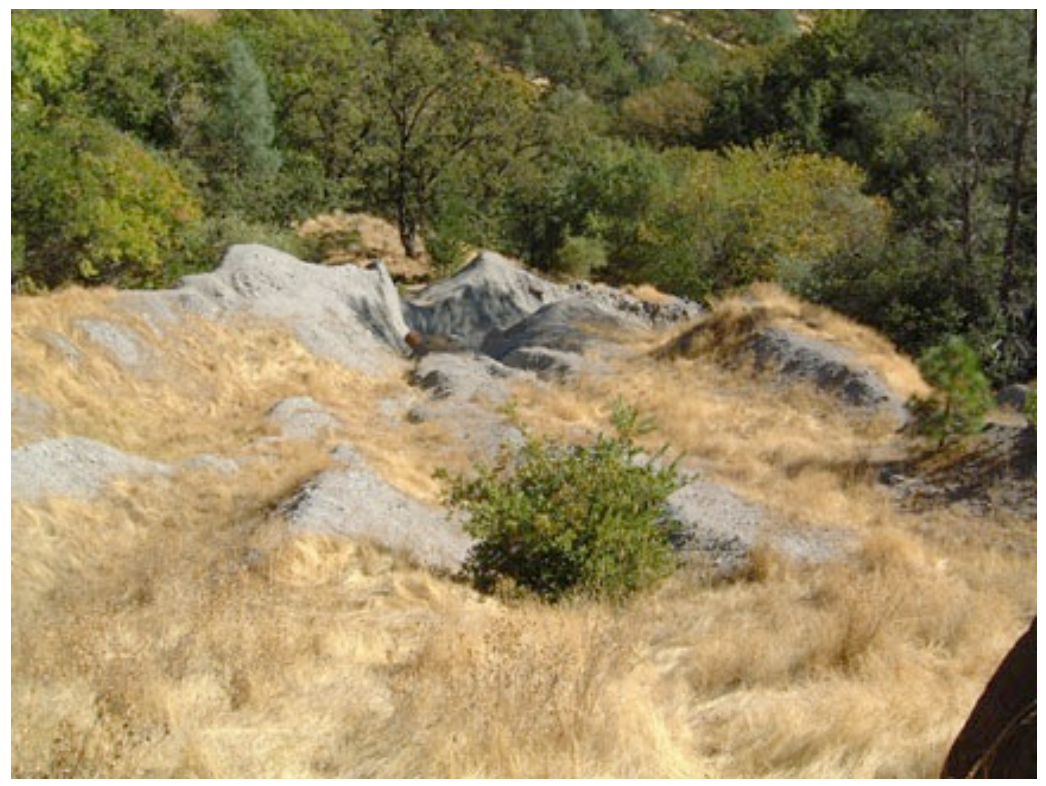

concentrate was processed in a one-pipe retort (Fig. 4). As a result, only a minimal amount of calcine generated from the retort was disposed of in the tailings pile.

Figure 3. Overview of tailings pile at the Oat Hill Extension. Note drainage channel containing barrels in central part of photo is shown in detail in Figure 12.

Mercury contamination of James Creek by cinnabar from the Oat Hill and OHE mines is substantial. Erosion down steep slopes of waste rock, tailings, and other mine waste at the Oat Hill and OHE seasonally replenished placer cinnabar deposits in James Creek (Yates and Hilpert, 1946). Some of the cinnabar from these deposits was recovered using a rocker (Fig. 5) and other placer mining techniques within a distance of $3 \mathrm{~km}$ downstream from the Oat Hill mine area.

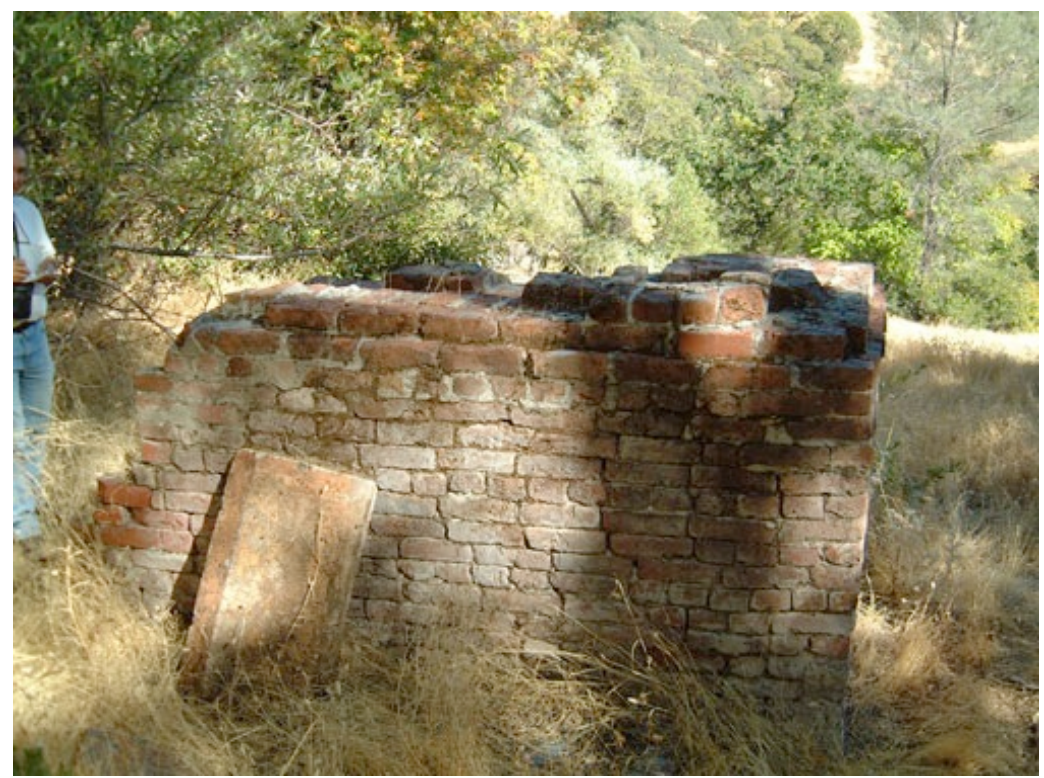

Figure 4. Remains of brick retort at Oat Hill Extension location of sample 23OE11.

\subsection{Transport and biogeochemistry of mercury in mine waste-contaminated sediments}

The transport of mercury from mercury mine waste materials, including waste rock and calcines, is usually dominated by $\mathrm{HgS}_{(\mathrm{s})}$ colloids (Conaway et al., 2004; Kim et al., 2004; Slowey et al., 2005a; Whyte and Kirchner, 2000). In addition, more soluble forms of mercury are released, a fraction of which is adsorbed to particles. ${ }^{2}$ During fluvial transport, $\mathrm{HgS}_{(\mathrm{s})}$ remains in sediments and soluble mercury may accumulate by binding to organic-rich material in sediments. Investigations at other sites by the authors have found evidence of anaerobiosis where plant roots trap sediment. While plant roots stabilize sediment at these locations, plant litter

\footnotetext{
${ }^{2}$ Speciation measurements by Kim et al. (2004) of a calcine sample at the Oat Hill mine found it to contain $940 \mathrm{ppm}$ total $\mathrm{Hg}$, consisting of (in order of increasing expected solubility) 60 percent cinnabar (alpha-HgS), 10 percent each of coderoite $\left(\mathrm{Hg}_{3} \mathrm{~S}_{2} \mathrm{Cl}_{2}\right)$ and terlinguite $\left(\mathrm{Hg}_{2} \mathrm{OCl}\right)$, and 20 percent $\mathrm{HgCl}_{2}$.
} 


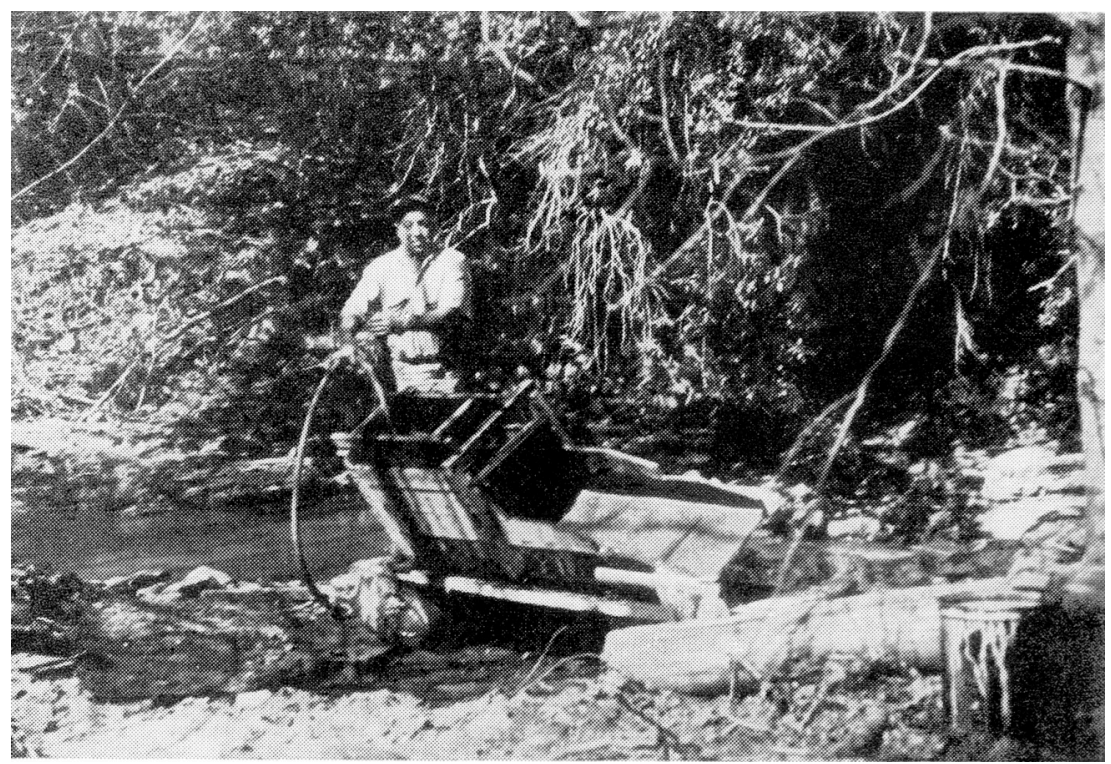

Figure 5. Historic placer mining of cinnabar using a rocker in James Creek below the Oat Hill Mine tailings.

provides organic matter, enhancing microbial activity. In sulfate-rich water, sulfide production has been observed in this type of environment, presumably due to the activity of sulfate-reducing bacteria (SRB). Some species of SRB are known to methylate mercury in freshwater sediments (Benoit et al., 2003; Gilmour et al., 1992). The abundant iron present in James Creek ${ }^{3}$ also likely affects the transport and biogeo-chemistry of mercury.

$\mathrm{Fe}(\mathrm{III})$-(hydr)oxide formed from pyrite weathering or microbially mediated $\mathrm{Fe}$ (II) oxidation is often fine-grained with high surface area (Banfield et al., 2000; Gilbert and Banfield, 2005; Kappler and Straub, 2005; Nordstrom and Southam, 1997). The properties of these types of particles are relevant in at least three respects to the reactivity of inorganic mercury (including its propensity to be methylated):

(1) $\mathrm{Hg}(\mathrm{II})$ will adsorb to Fe(III)-(hydr)oxide (Barrow and Cox, 1992),

(2) $\mathrm{Fe}(\mathrm{III})$-(hydr)oxide will readily react with sulfide, and

(3) bacteria can metabolically reduce $\mathrm{Fe}(\mathrm{III})$, potentially releasing sorbed $\mathrm{Hg}$ (II) into solution.

Some Fe(III)-reducing bacteria have also been found to methylate mercury (Fleming et al., 2006; Kerin et al., 2007). Geochemical reactions between Fe(III)-(hydr)oxide and sulfide appreciably affect the reactivity of $\mathrm{HgS}_{(\mathrm{s})}$ under anaerobic conditions, because sulfide oxidation by $\mathrm{Fe}$ (III) can result in the formation of polysulfide ions (Poulton et al., 2004; Pyzik and Sommer, 1981; Slowey and Brown Jr., 2007), which can increase the solubility of $\mathrm{HgS}_{(\mathrm{s})}$ by up to three orders of magnitude (Jay et al., 2000; Paquette and Helz, 1997) and make more mercury (initially as aqueous $\mathrm{Hg}$ (II)-polysulfide complexes) available for methylation (Benoit et al., 2001; Jay et al., 2002). The aqueous chemistry of polysulfide has been studied more to understand the diagenesis of iron and sulfur in sediments (Rickard and Morse, 2005).

Estimating the methylation potential of a system that has an abundant source of inorganic mercury such as James Creek is limited in part by the extent to which potentially relevant biogeochemical processes have been investigated and understood. Discussion of the results of

\footnotetext{
${ }^{3}$ Since 2003 , reductions in discharge of iron (hydr)oxide from the Twin Peaks and Corona mine sites through trench and settling basin construction has noticably reduced the amount of iron (hydr)oxide in James Creek, based on observations in January and March, 2007.
} 
this investigation explains how a sampling program may under-represent methylation potential in the absence of information on biogeochemical processes associated with methylation.

\section{Sample Locations and Methods}

\subsection{Sample Locations and conditions}

Samples were collected to assess the concentration of mercury and other potentially relevant chemical constituents in tailings at the OHE Mine, and in sediments, waters, and biota in James Creek and the unnamed tributary to James Creek that drains the mine area, here termed Tributary 1. Samples of tailings and sediments at the OHE Mine were collected on October 17, 2003. Water, sediment, and biota from James Creek and Tributary 1 were sampled on May 20, 2004, during early summer base stream-flow conditions. Flow measurements were not made at the time of sampling and, to our knowledge, no gage is present in the James Creek watershed. During both sampling times, the weather was stable and no precipitation occurred. Field sites are shown on Figure 1 and 2 and listed and described in Table 1. The geographic coordinates in Table 1 were obtained in the field using a hand-held global positioning system referenced to the NAD 27 datum.

Table 1. Sample locations and descriptions. See Fig. 1 and 2 for maps illustrating these locations and their hydrological relationship. Coordinates are based on the NAD 27 datum.

\begin{tabular}{|c|c|c|c|}
\hline Sample $^{1}$ & Latitutde & Longitude & Description \\
\hline 04JC1 & 38.66965 & 122.5178 & $\begin{array}{l}\text { James Creek above confluence with Oat Hill Extension drainage } \\
\text { (Tributary 1). }\end{array}$ \\
\hline 04JC2 & 38.67013 & 122.5142 & Tributary 1 at confluence with James Creek. \\
\hline 04JC3 & 38.66988 & 122.5127 & James Creek water below confluence with Tributary 1. \\
\hline 04OHE1(S) & 38.67857 & 122.5177 & OHE drainage (Drainage B) to Tributary 1 (spring water). \\
\hline 230E12 & 38.67910 & 122.51814 & OHE tailings above adit (upper tailings) \\
\hline 230E13S & \multicolumn{2}{|c|}{ Near OE12 } & Sediments near upper tailings \\
\hline $\begin{array}{l}230 \mathrm{O} 1 \\
\text { through } 9\end{array}$ & \multicolumn{2}{|c|}{ Near OHE1 } & OHE tailings or, with an 'S' suffix, sediments \\
\hline $230 \mathrm{E} 11$ & \multicolumn{2}{|c|}{ Near OHE1 } & Sample of retort brick \\
\hline 230E14 & 38.67752 & 122.51819 & OHE office site (background soil sample) \\
\hline CRN-D/U & 38.67077 & 122.5369 & James Creek up \& down-stream of lower Corona Mine adit \\
\hline
\end{tabular}

Notes: (1) 04 indicates samples taken in 2004; JC = James Creek; OHE = Oat Hill Extension Mine site.

\subsection{Sampling}

\subsubsection{Dry sediment and tailings}

Visually representative, 100 to $500 \mathrm{~g}$ samples of tailings were collected from the OHE tailings pile after removing the upper $2 \mathrm{~cm}$ of exposed tailings. Tailings were also sampled along Drainage A where exposed in vertical sections along the channel. Up to $500 \mathrm{~g}$ of air-dried tailings were placed in trace-metal free certified borosilicate glass jars with Teflon-lined caps (ICHEM Series 300). Grab samples of dry sediment consisting primarily of transported tailings (on the basis of visually similar composition and grain size) were similarly collected and stored. Most sediment clasts larger than coarse sand size $(2 \mathrm{~mm})$ were discarded. 


\subsubsection{Wet sediment and tailings}

Grab samples of wet sediments were collected for total mercury $\left(\mathrm{Hg}_{\mathrm{T}}\right)$ and monomethyl mercury (MMHg) analysis at three James Creek locations and in Tributary 1 (Figs. 1 and 2). On May 20, 2004, sediment samples, which consisted of silt and fine to medium sand-size particles, were taken from the active channel of the creek into $100-\mathrm{mL}$ polycarbonate jars. Samples were stored in coolers with ice immediately after collection and frozen upon return from the field within four hours after collection until shipped to the analytical laboratory. Samples were shipped with blue ice packs and arrived at the analytical lab at $15^{\circ} \mathrm{C}$, which is warmer than recommended for MMHg analysis (Bloom, 2001; USEPA2002). Once at the laboratory (May 24, 2004), sediment samples were frozen again until processed.

\subsubsection{Water}

Spring and stream water samples were collected with new $60-\mathrm{mL}$ sterile polypropylene syringes at the same time as sediments were collected on May 20, 2004. Bulk water samples were subsampled for analysis of metals and metalloids [to be referred to hereafter using the shorthand metal(loid)s] and anions. Subsamples for metal(loid)s determinations were acidified to $\mathrm{pH}<2$ with trace metal (Ultrex, J.T. Baker)-grade $\mathrm{HNO}_{3}$ and stored in acid-washed, high-density polyethylene (HDPE) bottles. Subsamples for anion and alkalinity measurements were filtered, stored in HDPE bottles, and chilled to approximately $4^{\circ} \mathrm{C}$ until analysis, in accordance with U.S. Geological Survey protocols (http://pubs.water.usgs.gov/twri9A). Water samples for analysis of anions alkalinity, and ICP-MS and ICP-AES analysis were filtered in the field with $0.45 \mu \mathrm{m}, 25-$ $\mathrm{mm}$ sterile cellulose acetate syringe filters. Field method blanks were collected for one site by processing deionized water according to the same procedures used for field samples (except for alkalinity).

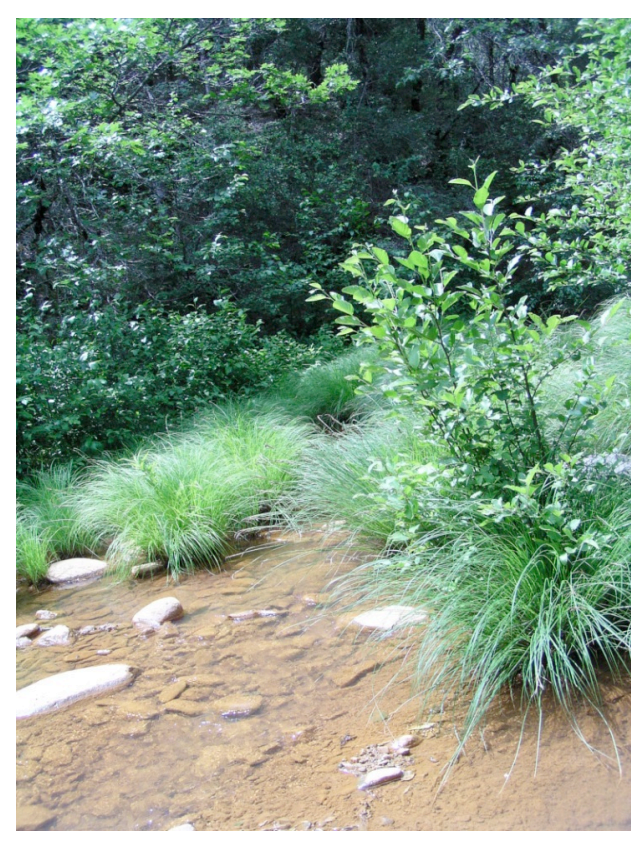

Water parameters including $\mathrm{pH}$, conductivity, and temperature were measured in the field with a Orion Model $290 \mathrm{pH}$ meter equipped with a temperaturecompensated electrode and an Orion Model 120 conductivity meter.

Samples for $\mathrm{Hg}_{\mathrm{T}}$ and $\mathrm{MMHg}$ analyses were obtained separately from the same location in James Creek and Tributary 1 in 1-L borosilicate bottles with no headspace using Teflon-lined caps (I-CHEM Series 300) following ultra-clean sampling and handling protocols (Bloom, 1995). Samples were kept on ice at approximately $5^{\circ} \mathrm{C}$ until analysis.

Figure 6. James Creek location JC1 upstream of OHE drainage sampled for biota in Spring and Autumn 2004. 


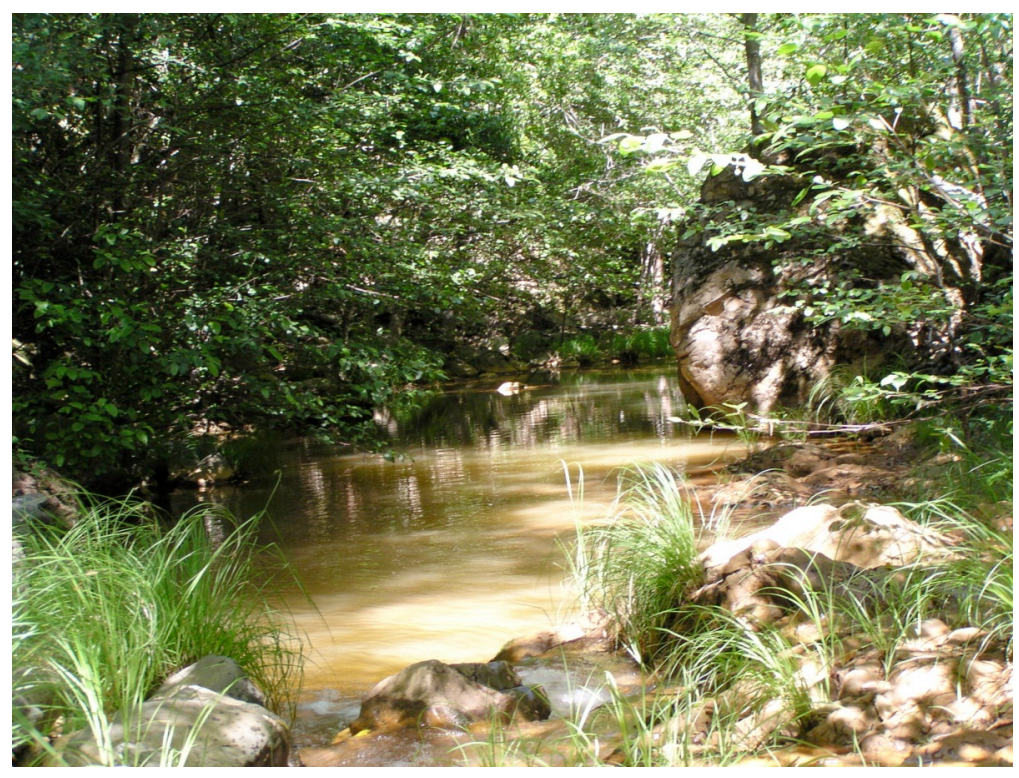

Figure 7. James Creek location JC3 downstream of Oat Hill Extension mine drainage sampled for biota in Spring and Autumn 2004.

\subsubsection{Biota}

Biological samples were collected from five sites in the James Creek watershed at the Oat Hill Extension mine area based on suspected $\mathrm{Hg}$ contamination and the presence of appropriate study organisms. Locations on James Creek upstream (JC1), above the confluence (JC2), and downstream (JC3) of Tributary 1 (Figs. 2, 6, and 7) and a small wetland area formed by a spring at location OHE1 (Figs. 1, 2 and 9) were sampled along with water and sediment on May 20, 2004. JC1, JC3, OHE1 and a location where lower Corona Mine ${ }^{4}$ adit drainage enters James Creek at the base of Kidd Canyon were sampled on October 29, 2004 (location CRN, Figs. 1 and 10).

Target macroinvertebrates for this study were predatory aquatic insects, collected depending on their abundance and availability at sampling sites. Preferred macroinvertebrates included: dragonflies (Odonata, families Gomphidae, Cordulegastridae, and Aeshnidae), beetles (Coleoptera, family Dyticidae, predaceous divingbeetles), aquatic and semi-aquatic predaceous insects of the order Hemiptera (family Gerridae, water striders; family Notonectidae, back swimmers; family Belostomatidae,giant water bugs), stoneflies (Plecoptera, family Perilidae), and dobsonflies (Megaloptera, family Corydalidae). Water striders are surface, not sediment feeders. Giant Waterbugs are of the same order (Hemiptera) as water striders, and similar to the striders, feed with piercing sucking mouthparts. However, they are not surface feeders like water striders, but feed within the water column and sediments. Dragonflies, dobsonflies, beetles, and stoneflies are benthic invertebrates and feed in sediment. Invertebrates were collected using dip nets or by hand, placed in zip-lock plastic bags with native water, kept on wet ice, and sorted at the end of each day.

Individual invertebrates were sorted by family and placed in disposable dishes using Tefloncoated forceps or a gloved hand. Organisms were thoroughly rinsed with deionized water and patted dry with clean paper towels. Up to 30 individuals of the same family were composited into 0.5 to $3 \mathrm{~g}$ samples in clean glass jars with Teflon-lined lids and frozen until shipped to the laboratory for analysis for total mercury and methyl mercury.

\footnotetext{
${ }^{4}$ Speciation measurements by Kim et al. (2004) of condenser soot at the Corona Mine found it to contain 550 ppm total $\mathrm{Hg}$, consisting of 50 percent cinnabar (alpha-HgS), 40 percent metacinnabar (beta-HgS), and 10 percent schuetteite $\left(\mathrm{Hg}_{3} \mathrm{O}_{2} \mathrm{SO}_{4}\right)$. Reductions of mercury transport achieved by recent construction of settling basins to intercept Corona Mine drainage have yet to be documented.
} 


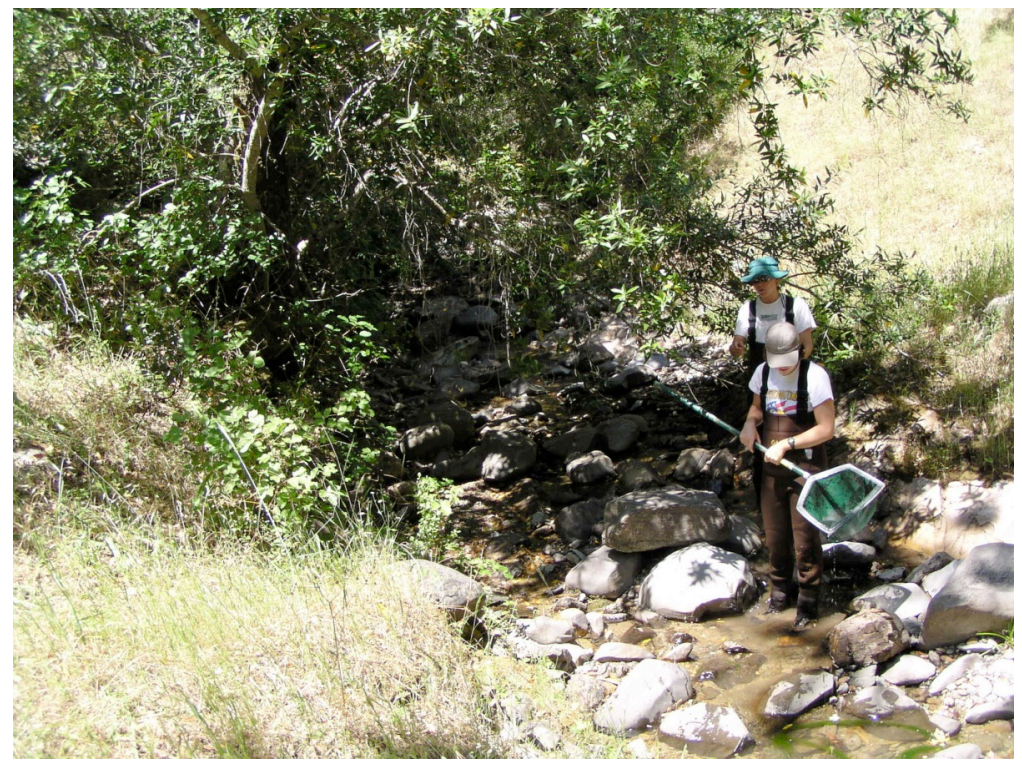

Figure 8. Sampling location JC2 on Tributary 1, spring 2004. The drain was dry in the Autumn sampling period, and no samples were collected.

Foothill yellow-legged frogs (Rana boylii) were captured by hand or with a net during the day: five in May and two in October, 2004. Foothill yellow-legged frogs appeared to be relatively abundant in James Creek in the spring, but few were seen in autumn of that year. Frogs were individually placed in plastic bags on wet ice, humanely euthanized with MS-222 the same day they were collected (American Society of Ichthyologists and Herpetologists et al., 1987), and frozen until processed within 2 days after collection.

Clean tools, weigh dishes, and disposable latex gloves were used to process each frog specimen to avoid cross contamination. Each frog was thawed, rinsed first with tap water to remove debris and then with deionized water, patted dry, and weighed $( \pm 0.1 \mathrm{~g})$. The snout-vent length (SVL) was measured using calipers $( \pm 0.1 \mathrm{~mm})$, and we examined each specimen for gross abnormalities. The digestive tract was removed, and the carcass, including the stripped and rinsed digestive tract, was placed in a clean jar (VWR TraceClean), sealed with Parafilm, and frozen at $-20^{\circ} \mathrm{C}$ pending chemical analysis for total $\mathrm{Hg}$.

Rainbow trout (Oncorhynchus mykiss) and California roach (Hesperoleucus symmetricus) were collected from the two James Creek sites (JC1 and JC3; Fig. 1) in spring of 2004 using a backpack electroshocker. Similar sizes and species were collected at each site as much as possible. Captured fish were held in buckets with native water and then euthanized. Each fish was weighed using an electronic balance $( \pm 0.1 \mathrm{~g})$, measured using a measuring board $( \pm 0.1$ $\mathrm{mm}$ ) for 'standard' and 'total' length, individually wrapped in aluminum foil, placed in zip-lock bags, and placed on wet ice in a cooler. 'Standard' length is defined as the distance from the tip of the closed mouth to the posterior end of the caudal peduncle, whereas 'total' length is the distance from the closed mouth to the extreme tip of the caudal fin. Samples were stored frozen until they could be processed. In the laboratory, individual fish were examined for gross deformities, dissected to determine sex, and the gastrointestinal tract removed and foods preserved for later identification. Carcasses, less the food contents, were stored frozen in chemically cleaned jars for later analysis for total mercury. 


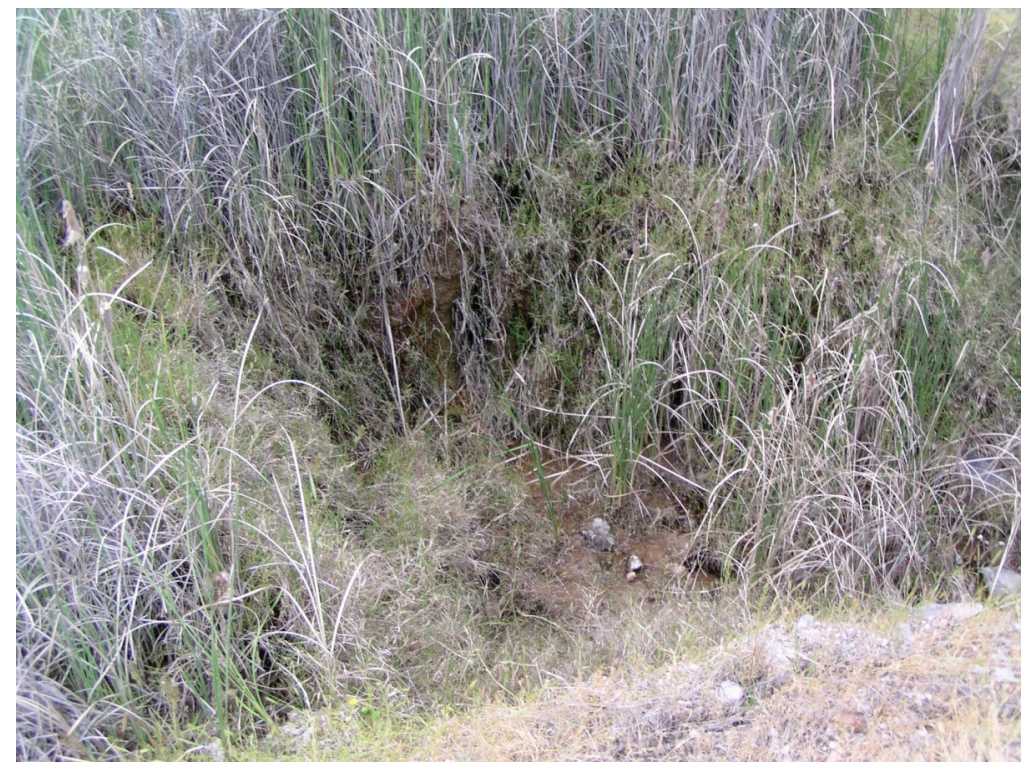

Figure 9. Wetland area near Oat Hill Extension Mine (OHE1, Fig. 2) sampled for biota in Spring and Autumn 2004.

\subsection{Analytical Methods}

\subsubsection{Sediment and tailings}

Multi-element analyses for all tailings and dry sediments were performed in the laboratories of ALS Chemex (Reno, NV). Bulk samples were ground in a zirconia ring mill and subjected to a neartotal four-acid digestion. Major elements were determined by inductively coupled plasma-atomic emission spectroscopy (ICP-AES). Trace elements other than mercury were determined by inductively coupled plasma-mass spectrometry (ICP-MS). Mercury was determined by cold vapor atomic absorption spectroscopy (CVAAS) following methods similar to those described by Crock (1996) and O'Leary and others (1996).

Mercury and MMHg analyses of wet sediments were carried out by Brooks Rand (Seattle, WA). Sediment subsamples were not homogenized prior to analysis. For total mercury, approximately one gram of sediment was digested with $7 \mathrm{~mL}$ conc. nitric acid plus $3 \mathrm{~mL}$ conc. sulfuric acid and heated to $100^{\circ} \mathrm{C}$ for one hour, followed by refluxing at $150^{\circ} \mathrm{C}$ for two hours in a glass vial with Telon-lined lids. $\mathrm{BrCl}$ was added to the digestate after it had cooled to room temperature, diluted to $40 \mathrm{~mL}$ with deionized water, further diluted by 40 to 100 -fold (such that the concentration was within instrumental range), and followed by stannous chloride reduction, single-stage gold amalgamation, and cold vapor atomic fluorescence spectroscopy (CVAFS) (U.S. EPA Method 1631E). The acid digestion procedure should recover elemental, adsorbed, and almalgamated

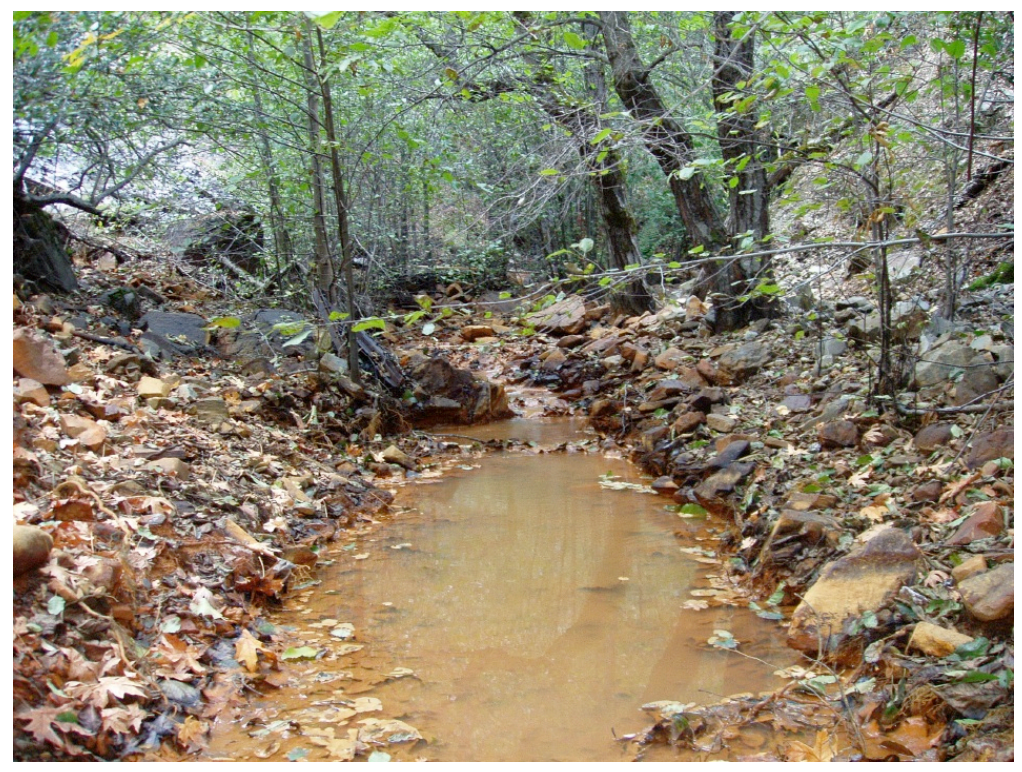
mercury, and mercury sulfide $\left(\mathrm{HgS}_{(\mathrm{s})}\right.$, including cinnabar and metacinnabar), but does not appreciably dissolve silicate minerals.

Figure 10. James Creek site downstream of lower Corona Mine adit (Fig. 1) sampled for biota in Autumn 2004. 
Previous studies suggest that mercury is sorbed to aluminosilicate minerals that exist in fluvial sediment such as those studied here, but only minor fractions of mercury have been found within aluminosilicate mineral structures (Lowry et al., 2004; Slowey et al., 2005b). MMHg in sediment was determined by acid bromide-methyl chloride extraction, followed by aqueous phase ethylation, isothermal gas chromatographic separation, and CVAFS detection (Horvat et al., 1993b). Results are reported on both a wet- and dry-weight basis, with the latter calculated from wet concentrations and gravimetrically measured sediment water contents. Detection limits for $\mathrm{Hg}_{\mathrm{T}}$ and $\mathrm{MMHg}$ in sediment were $0.12 \mathrm{ng} / \mathrm{g}$ and $0.02 \mathrm{ng} / \mathrm{g}$, respectively, representing three standard deviations above mean values derived from multiple analyses of blanks. NIST-certified mercury standard reference materials were measured, including $\mathrm{MMHg}$ standards made from pure powder and calibrated against NBS-3133, and cross verified by daily analysis of Certified Reference Material DORM-2 (National Research Council of Canada Institute for National Measurement Standards, 1999).

\subsubsection{Waters}

Alkalinity was measured two to four days after sample collection by titration with sulfuric acid using Gran's technique (Rounds, 2006). Sulfate, chloride, nitrate, and fluoride were determined by ion chromatography (Fishman and Friedman, 1989). Cations were analyzed by ICP-AES and ICP-MS. Duplicate water samples, blank samples, and USGS Water Resource Division standard reference waters were analyzed with the data set and yielded acceptable results.

Samples for $\mathrm{Hg}_{\mathrm{T}}$ and $\mathrm{MMHg}$ analyses were handled in a Class-100 clean-air station to minimize sample contamination (Brooks Rand, Seattle, WA). $\mathrm{Hg}_{\mathrm{T}}$ was measured by bromine monochloride $(\mathrm{BrCl})$ oxidation followed by $\mathrm{SnCl}_{2}$ reduction, single-stage gold amalgamation, and detection by CVAFS (EPA Method 1631Bloom et al., 1988). MMHg was analyzed using aqueous phase ethylation with purging onto Carbotrap, gas chromatographic (GC) separation, isothermal decomposition, and CVAFS detection (Horvat et al., 1993a). Detection limits for $\mathrm{Hg}_{\mathrm{T}}$ and $\mathrm{MMHg}$ in water were $0.2 \mathrm{ng} / \mathrm{L}$ and $0.04 \mathrm{ng} / \mathrm{L}$, respectively, based on three standard deviations above mean values for multiple blanks.

\subsubsection{Biota}

All samples collected in May were analyzed by the Trace Element Research Laboratory (TERL, College Station, TX), while the samples collected in October were analyzed by Brooks Rand (Seattle, WA). At Brooks Rand, for $\mathrm{Hg}_{\mathrm{T}}$, samples were digested in a mixture of nitric and sulfuric acid and then oxidized with $\mathrm{BrCl}$, and the digestates analyzed for $\mathrm{Hg}_{\mathrm{T}}$ as explained in section 2.3.2. At Brooks Rand, for $\mathrm{MMHg}$, samples were digested in $\mathrm{KOH}$-methanol solution, and the digestates analyzed for $\mathrm{MMHg}$ as explained in section 2.3.2. Moisture content was determined by weight loss upon freeze-drying and was expressed as a percent of the original wet sample weight. Mercury and MMHg concentrations are reported on a wet-weight basis.

At TERL, tissue samples were homogenized in the original sample containers either after freezedrying or with a Tekmar Tissumizer and subsampled. Subsamples were digested with nitric acid, sulfuric acid, potassium permanganate, and potassium persulfate in polypropylene tubes in a water bath at $90-95^{\circ} \mathrm{C}$, according to a modified version of EPA methods 245.5 and 245.6. Before total $\mathrm{Hg}$ analysis, hydroxylamine hydrochloride was added to digestates to reduce excess permanganate. Digestates were brought to volume with deionized water and analyzed using 


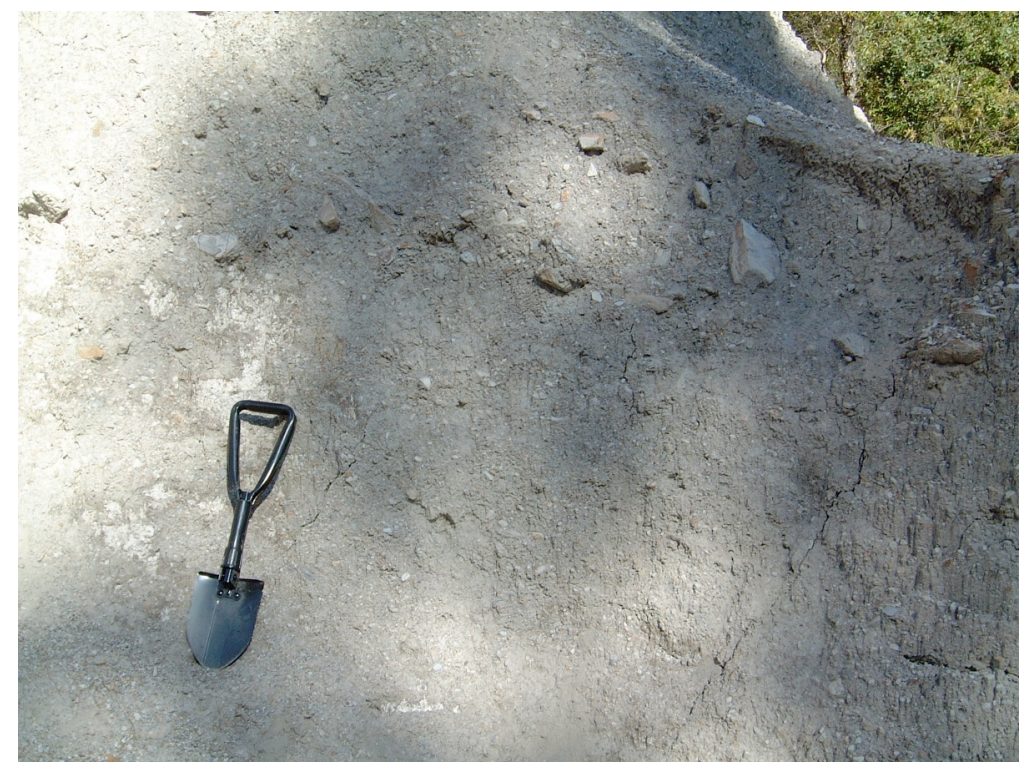

Figure 11. Exposure of coarse grained tailings at the lower part of the Oat Hill Extension tailings pile, site of sample 23OE1. Tailings appear to be coated by white efflorescent salts.

stannous chloride reduction, purging and cold-vapor atomic absorption spectroscopy (CVAAS) detection.

Determination of methylmercury in biota was based on extraction of organo-mercury compounds at TERL following the method of Uthe et al. (1972). Organic mercury compounds were extracted from homogenized tissue aliquots using an organic solvent amended with potassium bromide and copper sulfate to improve partitioning from the aqueous to the organic phase. The organic phase was digested in combusted glass vials using nitric and sulfuric acids and potassium permanganate, to convert all $\mathrm{Hg}$ species to ionic $\mathrm{Hg}$ (II) and to remove traces of organic solvent that would otherwise affect the measurement. The digestates were finally analyzed by CVAAS.

\subsection{Geochemical Modeling}

A thermodynamic model was used to compare ion activity products of major elements in James Creek water and OHE drainage to the solubility of minerals that may precipitate and dissolve

under low-temperature aqueous conditions. The computer program Geochemist's Workbench (version 6) estimated activities from concentrations using a modified form of the "B-dot" equation (Helgeson, 1969) and computed the saturation index, S.I. $=Q / K$, for minerals contained in the 'thermo.dat' database (http://www.geology.uiuc.edu/Hydrogeology/hydro_thermo.htm), where $Q$ is the ion activity product of a given mineral's constituents (e.g., $\mathrm{Mg}^{2+}$ and $\mathrm{CO}_{3}{ }^{2-}$ for magnesite) and $K$ is the solubility product of that mineral. Calculations used a constituent basis estimated from water quality (temperature, $\mathrm{pH}$, and alkalinity) and aqueous constituent measurements, included a fixed sea-level atmospheric oxygen fugacity of 0.2 (approximately 10 $\mathrm{mg} / \mathrm{L}$ dissolved oxygen), and took ion-pairing into account.

\section{Results}

\subsection{Tailings and Dry Sediment at OHE Mine}

Ore processing at the Oat Hill Extension (OHE) resulted in significant residual cinnabar and pyrite in the tailings. The OHE mill feed, consisting of sandstone and former tailings from the Oat Hill Mine operation, was gravimetrically separated but not heated. This method is in contrast to the more typical process of roasting, which would have removed more mercury and oxidized minerals such as pyrite. Waste pile tailings are stratified based on clast size, apparently ranging 
from coarse sand to coarse gravel (Fig. 11). The coarser tailings occur in the northern part of the pile (sample 23OE9; Fig. 2), and reflect accumulation of oversize clasts rejected from the trommel. Tailings in the southern part of the pile, samples 23OE1 through 5 (Fig. 2), consist primarily of undersize clasts rejected from the concentrating tables.

The geochemical results for samples of mill tailings at the OHE are listed in Table 2 (appended). The mercury concentrations in the tailings range from 400 to $1000 \mu \mathrm{g} / \mathrm{g}$ (ppm). Tailings present above the adit in the northern-most part of the mine area, sample 23OE12 (Fig. 2), have the highest concentration of mercury $(1175 \mathrm{ppm})$. Other potentially toxic metal(oid)s are present at lower concentrations, including arsenic (0.2-6 ppm), copper (30-50 ppm), nickel (50-70 ppm), lead (10-20 ppm), and zinc (90-130 ppm) (discussed further below).

Background soil sampled at the OHE at a distance of $0.5 \mathrm{~km}$ from the retort site has a mercury concentration of approximately 7 ppm (23OE14; Fig. 2). The high level of mercury in the soil is either due to mercury mineralization of the sandstone from which the soil developed or atmospheric deposition following emission from retort and furnace stacks at the Oat Hill and

adjacent Corona and Twin Peaks mine sites (Ericksen et al., 2005; Gustin et al., 2003; Gustin et al., 2004). Further soil sampling is required to evaluate disseminated mineralization and furnace emissions as sources of mercury to the James Creek area.

Elevated mercury concentrations exist in sediment sampled from a channel that transects the upper and lower part of the tailings, here termed Drainage A (Fig. 2). The mercury concentration of sediment in the upper part of Drainage A is 930 ppm (sample 23OE13S), increasing to 1500 ppm (sample 23OE3S) in the lower part of the drainage where it incises the main tailings pile (Figs. 2 and 12). Since the 'upper tailings' piles (location 23OE13S) apparently contain high concentrations of mercury, a portion of the mercury in sediment sampled downstream at location $23 \mathrm{OE} 3 \mathrm{~S}$ could have come from the 'upper tailings' piles. However, since the downstream sample site is located at the tail-end of the OHE tailings piles, the mercury measured in the sediment there could have originated from the OHE tailings alone or from both the OHE tailings and contaminated sediment originating from the 'upper tailings.' That the mercury concentration measured at the downstream location was higher than at the 'upper tailings' location could suggest that mercury is released from the 'upper tailings,' transported down to the OHE site, and mixed with OHE tailings-contaminated sediment in such a way that the mercury concentration is augmented, and then finally discharged at the tail-end of the OHE. Since mercury does not transport conservatively, and in the absence of any hydrological information, the hypothesis stated above cannot be resolved by this simple comparison. Even this small region would require a detailed (e.g., including suspended solids concentrations under different flow regimes), highresolution characterization to determine from where and in what quantities mercury originates.

Drainage A was dry at the time of sampling, but intense rain in winter probably transports mercury-enriched sediment from the tailings pile into Tributary 1 and then James Creek. The data are consistent with the hypothesis that winter runoff from the Oat Hill and OHE areas replenishes cinnabar in the James Creek placer (Yates and Hilpert, 1946). 


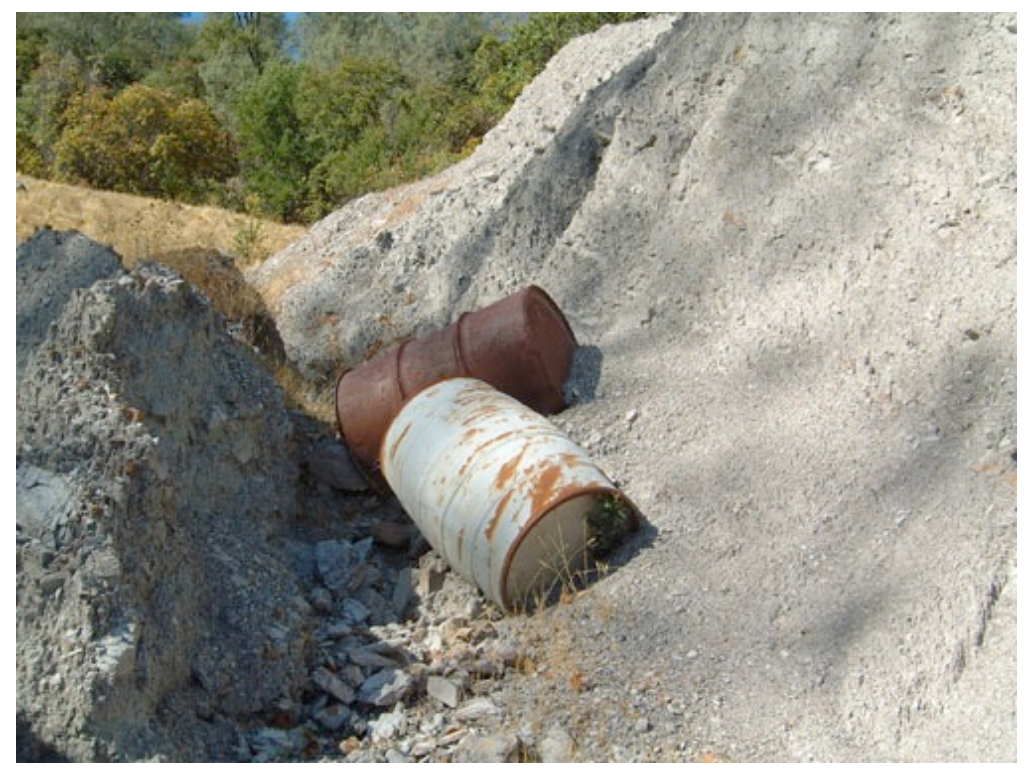

Figure 12. Sediment in Drainage A located in the lower part of Oat Hill Extension tailing pile.

Concentrations of mercury, copper, lead and zinc in the lower tailings pile at the OHE site, two sediment samples from Drainage A from the OHE, and tailings above the adit exceed USBLM Robin Scenario (RS) ecotoxicity screening criteria. In addition, five lower tailings samples, two sediment samples from the OHE drainage ditch, and the 'background' soil sample taken at the OHE office site contained arsenic (As) concentrations exceeding the USBLM's RS ecotoxicity screening criteria. Comparisons of all element concentration results with the USBLM's Human Risk Management Camper Scenario and US Environmental Protection Agency preliminary remediation goals (USEPA-PRG) criteria are provided in Table 2. One OHE tailings contained As and chromium exceeding USEPA-PRG criteria, and all but one sample exceeded the USEPA-PRG thorium criterion. All but two samples (retort brick and background soil) exceed the the USBLM Camper Scenario criterion for mercury. Brick and mortar from the retort used to process cinnabar concentrates from the OHE Mine have a relatively low mercury concentration ( $5 \mathrm{ppm})$, although it exceeds the USBLM's RS ecotoxicity screening criterion. Other metals that exceed this criteria for this material include $\mathrm{As}, \mathrm{Cu}, \mathrm{Pb}$, and $\mathrm{Zn}$ (Table 2).

\subsection{Water and Sediment in James Creek and the Tributary Draining the OHE Mine}

In summarizing our mercury monitoring results, we cite predefined water, sediment, and biota quality criteria to compare our observations with what is currently thought by public agencies to pose ecological risk due to mercury in organisms such as piscivorous fish and birds. In California mine-impacted systems, multiple criteria are used, including concentrations of $\mathrm{Hg}_{\mathrm{T}}$ or $\mathrm{MMHg}$ in water, sediment, fish, or combinations thereof. As further explained in sections 3.2.1 and 3.3.3, direct comparison of a given mercury concentration with the predefined criterion of similar analyte and medium is inappropriate, because multiple and often undisclosed/implicit assumptions used to derive the criterion do not fully apply to the present case. Although beyond the scope of this report, we note that some predefined criteria also intertwine causal relationships derived from seemingly incompatible conceptual models. Ultimately, we cite these predefined criteria to promote awareness and further elucidate the limitations of both the current data set and the criteria themselves.

\subsubsection{Mercury and monomethyl mercury}

Water and sediment were sampled from a tributary that drains the OHE Mine area (termed Tributary 1), and in James Creek in order to assess whether mercury and associated elements were being transported from the mine site into James Creek. In Tributary 1 water just above the 
confluence with James Creek, the $\mathrm{Hg}_{\mathrm{T}}$ concentration was $14 \mathrm{ng} / \mathrm{L}$ (sample 04JC2, Table 3). In James Creek, $\mathrm{Hg}_{\mathrm{T}}$ concentrations below this confluence was 55 percent higher than above (7.3 vs. $4.8 \mathrm{ng} / \mathrm{L}$; sample 04JC3 vs. 04JC1; Table 3), suggesting that mercury is transported through Tributary 1 to James Creek under base flow conditions. Filtered mercury concentrations in Tributary 1 and James Creek waters account for 50 to 60 percent of $\mathrm{Hg}_{\mathrm{T}}$. Drainage from a spring located below the adit of the OHE Mine (termed Drainage B; Fig. 2) is an important source of mercury to Tributary 1, since it contains an exceptionally high $770 \mathrm{ng} / \mathrm{L} \mathrm{Hg}_{\mathrm{T}}$ (sample 04OHE1; Table 3). The water from this spring deposits calcite and magnesite, on the basis of visual observation of the sediment in the spring area and thermodynamic calculations (\$3.2.2). This deposition may enhance the accumulation of mercury in OHE drainage sediment $(110 \mu \mathrm{g} / \mathrm{g}$-dry was measured in sample 04OHE1; Table 3).

MMHg concentrations in waters of James Creek and Tributary $1(0.04$ to $0.08 \mathrm{ng} / \mathrm{L})$ are lower than those typical for mine impacted watersheds ( 0.1 ng/L; Krabbenhoft et al., 1999), but are near or above a proposed level (0.04 to $0.06 \mathrm{ng} / \mathrm{L} \mathrm{MMHg}$ on an annual-averaged basis of undefined statistical population) for the mercury mine-impacted Tomales Bay (Marin County), California watershed (Marshall, 2006) ${ }^{5}$. The spring water with the relatively high $\mathrm{Hg}_{\mathrm{T}}$ concentration at the $\mathrm{OHE}(770 \mathrm{ng} / \mathrm{L})$ had the highest MMHg concentration, $0.09 \mathrm{ng} / \mathrm{L}$, which is more typical of mine impacted waters and yet was only 0.01 percent of $\mathrm{Hg}_{\mathrm{T}}$. Invertebrates from this location also had higher levels of $\mathrm{MMHg}$ (section 3.3.1). These results should be interpreted with caution for two reasons: (1) sample storage may have resulted in $\mathrm{MMHg}$ degradation prior to analysis (Bloom, 2001; Parker and Bloom, 2005) and, more importantly, (2) the waters were oxygenated and sunlit, which can promote biological and photochemical degradation of $\mathrm{MMHg}$ (Benoit et al., 2003; Sellers et al., 1996), reducing the likelihood of measuring all of the MMHg produced in sediment, resulting in an unrepresentative coverage of the system's total methylation potential. This sampling bias results in concentrations that are so small as to be especially prone to error when used to relate water quality to impacts on biota. Pore waters at these sample sites should be analyzed to better assess the methylation potential at each site, as discussed at the end

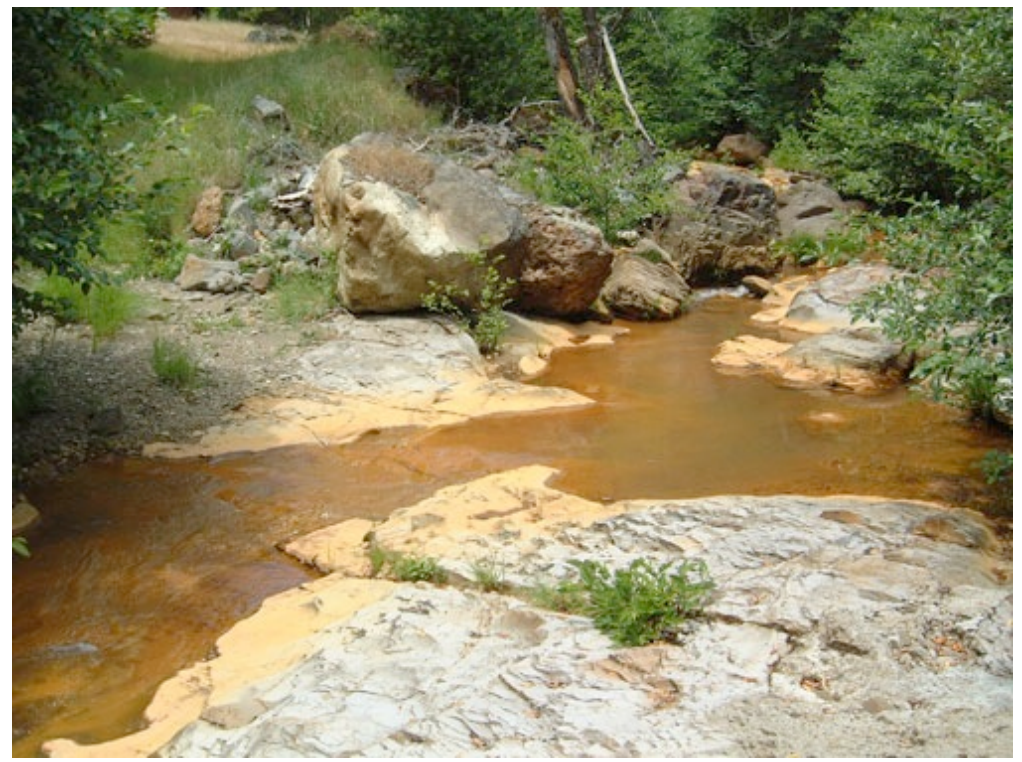
of this section.

Figure 13. James Creek at water, sediment and biota sample site 04JC1. Iron staining on rocks in creek results from precipitation of iron (hydr)oxide from the Corona and Twin Peaks mines.

High concentrations of mercury are present in sediment from the active channel of James Creek (Figs. 2 and 13, sample site 04JC1), indicated by panned concentrates that contain a large amount of cinnabar (Figs. 14) and high concentrations of mercury in

\footnotetext{
${ }^{5}$ This criterion is accompanied by sediment criteria, which arguably is an example of the use of incompatible conceptual models to derive a mercury concentration-ecological impairment relationship.
} 
sediment (7 to $21 \mathrm{ppm}$; samples 04JC1 and 04JC3, Table 3). Mercury concentrations in sediment and the amount of cinnabar in the panned concentrate were highest at sample site 04JC1, located above the confluence with Tributary 1 (Fig. 2). Mercury concentrations and the amount of cinnabar in the panned concentrate decrease downstream from the confluence with Tributary 1. Concentrations in Tributary 1 (3 ppm, sample 04JC2), are lower than at both samples sites (04JC1and 04JC3) in James Creek. The data suggest that although Tributary 1 is a source of mercury-enriched sediment to James Creek, more significant sources of mercury-enriched sediment exist upstream of Tributary 1 . These results must be qualified using quality control analyses, as follows.

Duplicate matrix spike analyses of total mercury in sediment revealed a heterogeneous distribution of mercury within a given grab sample. Recoveries of mercury from two unspiked sample aliquots actually exceeded those of two spiked aliquots from the same sample. This result, and the presence of cinnabar in the creek sediments, suggests that subsamples from a given grab sample contain different amounts of cinnabar. Another less likely source of variability may have been inconsistent (i.e., matrix-dependent) and incomplete digestion of mercury (primarily cinnabar).

For these reasons, future sediment investigations should include the following: (1) to determine whether there is a 'nugget effect' due to a heterogeneous distribution of mercury, split large samples into equally sized subsamples (according to mass) and analyze, (2) to prevent exclusion of cinnabar particles when subsampling just prior to analysis (as commonly occurs at commercial laboratories) and to facilitate subsample digestion, thoroughly homogenize (sub)samples, and, (3) to assess which sample size is statistically representative of the bulk sediment volume that one wishes to quantify, analyze a series of samples of increasing size (e.g., $1,10,20,50,100 \mathrm{mg}$, etc., each homogenized) taken from the same bulk sediment volume. As sample size increases, the mercury concentrations recovered should converge on a representative value. Ideally, for sediments along a drainage channel, the bulk sediment volumes for which representative sample sizes are determined would adjoin. Practical sampling limitations result in bulk sediment volumes separated in space, with unknown but potentially quantifable implications for the reliability of sediment mercury measurements and the conclusions about mercury transport derived from these data. Despite uncertainty in the concentration of $\mathrm{Hg}_{\mathrm{T}}$ in sediments of James Creek and its tributaries, the level of mercury contamination is apparently high compared to criteria developed for total mercury in mine-contaminated sediments elsewhere in California. For example, Tomales Bay (Marin County): $5 \mu \mathrm{g} / \mathrm{g}$ in sediment close to mine waste and $0.5 \mu \mathrm{g} / \mathrm{g}$ further downstream (Marshall, 2006).

$\mathrm{MMHg}$ concentrations in sediments were relatively low in comparison to sediments from mineimpacted watersheds, which average $1.9 \mathrm{ng} / \mathrm{g}$ (Krabbenhoft et al. 1999). Even in the sediment at the OHE with the highest total mercury concentration, the $\mathrm{MMHg}$ concentration was only 0.7 $\mathrm{ng} / \mathrm{g}$. In addition to the caveats stated earlier for $\mathrm{MMHg}$ in water, one sample from James Creek (04JC2) and another from Drainage B (04OHE1) had MMHg concentrations (Table 3) above the method detection limit (MDL) but below a statistically quantifiable concentration (i.e., 10x MDL), and therefore are of questionable value in examining relationships between $\mathrm{MMHg}$ in water and $\mathrm{MMHg}$ in biota. Nevertheless, high levels of mercury present in sediment and water at the OHE spring, Tributary 1, and James Creek did not result in correspondingly high 
concentrations of $\mathrm{MMHg}$ in the apparently aerobic water and sediment sampled. The biogeochemical basis for this observation is discussed below.

Cinnabar is typically more soluble under anaerobic, sulfidic conditions (Jay et al., 2000) or in the presence of humic substances (Waples et al., 2005), neither of which characterize the OHE and James Creek sediments sampled in this investigation. Since cinnabar is probably the dominant mercury species in the sediments, the lack of methylation is likely due to the stability of cinnabar under the conditions sampled. To better evaluate the system's true methylation potential, future investigations of James Creek should locate and enumerate zones of anaerobic sediments and analyze the $\mathrm{Hg}_{\mathrm{T}}$ and $\mathrm{MMHg}$ contents in pore water at these locations.

To more reliably characterize and compare methylation potential among various sites, sampling procedures that minimize ex situ environmental and handling effects are needed. For example, if saturated sediments up- and downstream of a mine tailings pile produce $\mathrm{MMHg}$, sediment porewaters will likely contain higher concentrations of $\mathrm{MMHg}$ than overlying water, since MMHg will be dispersed and possibly abiotically and biotically degraded (Benoit et al., 2003) as it transports into the water column. If overlying water is sampled at each location, differences in $\mathrm{MMHg}$ concentrations may be due to varying degrees of dispersion and/or degradation, not neccessarily a difference $\mathrm{MMHg}$ production.
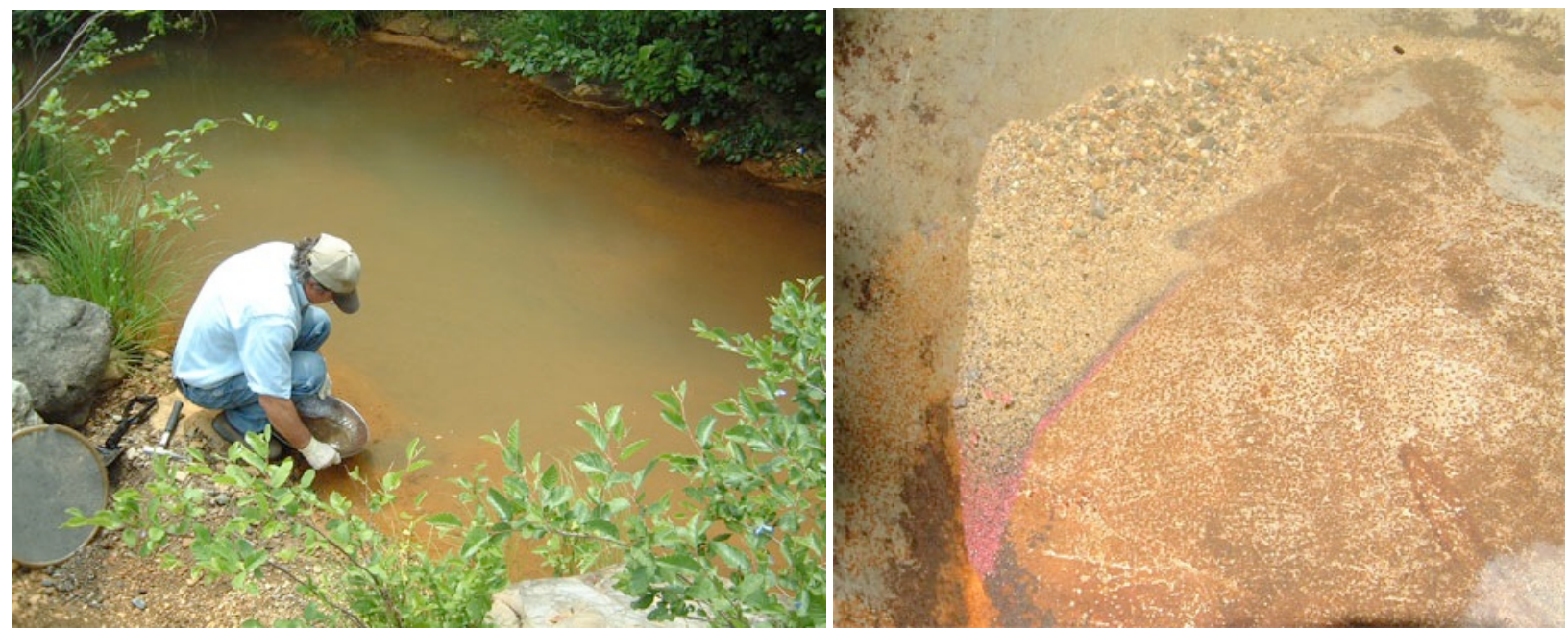

Figure 14. (a) James Creek at sample site 04JC1. Sediment consists of medium to coarse sand and fine silt to clay sizes, the latter containing iron (hydr)oxides derived from Corona and Twin Peaks mine drainage. (b) Cinnabar present in panned concentrate from this location. 
Table 3. Mercury and methyl mercury in water and sediment. Error intervals (2 $\sigma$ of duplicate analyses, or 95 percent confidence level) are reported where they are on the order of the last significant digit.

\begin{tabular}{|c|c|c|c|c|c|c|c|c|}
\hline \multirow[t]{2}{*}{ Sample } & \multicolumn{2}{|c|}{ Mercury in water ${ }^{1}$} & \multicolumn{2}{|l|}{$\begin{array}{l}\text { Monomethyl } \\
\text { mercury } \\
\text { in water }{ }^{2}\end{array}$} & \multicolumn{2}{|c|}{$\begin{array}{l}\text { Mercury in } \\
\text { sediment }{ }^{3,6}\end{array}$} & \multicolumn{2}{|c|}{$\begin{array}{l}\text { Monomethyl mercury } \\
\text { in sediment }\end{array}$} \\
\hline & unfiltered & $\begin{array}{c}\text { Filtered } \\
(<0.45 \\
\mu \mathrm{m})\end{array}$ & Unfiltered & $\begin{array}{l}\text { Wt } \% \\
\text { Solid }\end{array}$ & $\begin{array}{l}\mu \mathrm{g} / \mathrm{g} \\
\text { wet }\end{array}$ & $\begin{array}{l}\mu g / g \\
d r y^{1}\end{array}$ & $\begin{array}{l}\mathrm{ng} / \mathrm{g} \\
\text { wet }\end{array}$ & $\begin{array}{l}\mathrm{ng} / \mathrm{g} \\
\mathrm{dry}\end{array}$ \\
\hline 04JC1 & $4.8 \pm 0.9$ & $2.8 \pm 0.5$ & 0.04 & 79 & 17 & 21 & 0.72 & 0.92 \\
\hline 04JC2 & $14 \pm 3$ & $7.8 \pm 1.5$ & 0.08 & 76 & 2.5 & 3.3 & 0.06 & 0.08 \\
\hline 04JC3 & $7.3 \pm 1.4$ & $3.4 \pm 0.6$ & 0.04 & 72 & 5.0 & 6.9 & 0.05 & 0.07 \\
\hline 04OHE1 & $780 \pm 150$ & $5.8 \pm 1.1$ & 0.10 & 57 & $64^{6}$ & 110 & 0.43 & 0.74 \\
\hline
\end{tabular}

Notes: Analytical detection limits based on $3 \sigma$ of reagent blank recoveries were (1) $0.2 \mathrm{ng} / \mathrm{L}$, (2) 0.04 $\mathrm{ng} / \mathrm{L}$, (3) $0.12 \mathrm{ng} / \mathrm{g}$, and (4) $0.02 \mathrm{ng} / \mathrm{g}$.

(5) Concentrations on a dry weight basis were computed by dividing the $\mathrm{ng} / \mathrm{g}$-wet sediment by the wtpercent solids of the sediment.

(6) Matrix spike recovery was less than unspiked recovery, indicating substantial heterogeneity in the distribution of $\mathrm{Hg}$ within the sediment sample. The true bulk concentration of this and the other sediment samples may be substantially different than these reported values.

In the current study, these processes could not be evaluated because the MMHg concentrations are so low as to be indistinguishable by biogeochemical interpretation. Minimizing ambiguities of dispersion and degradation through appropriate sampling is the first step towards a more direct evalution of methylation potential. Higher, distinguishable $\mathrm{MMHg}$ concentrations, perhaps 1 to $10 \mathrm{ng} / \mathrm{L}$ differing by tens of percent, would indicate appreciable differences in $\mathrm{MMHg}$ production, pending the development of a statistically based method that accounts for biogeochemical effects (i.e., systematic variability). Differences in MMHg production would further imply differences in the locations' abilities to labilize mercury into forms more reactive than cinnabar. $\mathrm{MMHg}$ production differences also likely reflect the activity of bacterial populations that are methylating $\mathrm{Hg}$ (II). In situ sediment pore water sampling using passive or vacuum membrane samplers [e.g., peepers, 'Rhizon' samplers (Seeberg-Elverfeldt et al., 2005), or other high-resolution devices (Merritt and Amirbahman, 2007; Sigg et al., 2006)] will likely recover higher concentrations of $\mathrm{MMHg}$ compared to flowing creek water where $\mathrm{MMHg}$ that originated in sediment pore water is dispersed in a demethylating environment. The effect of dispersion is clearly evident when comparing $\mathrm{MMHg}$ measurements of field samples versus laboratory sediment incubations (Bloom, 2001). Despite the vastly different $\mathrm{MMHg}$ concentrations observed in preserved field samples (to estimate in situ MMHg concentrations) and field or laboratory reactors, both are used to infer the degree to which inorganic $\mathrm{Hg}$ is susceptible to methylation. More reliable assessment of the propensity for inorganic mercury to be methylated will be achieved by determining $\mathrm{MMHg}$ concentrations in field samples obtained directly from potential methylation sites by improved sampling methods such as those above.

Reliable assessment of methylation potential is critical to understanding how and to what extent the inorganic $\mathrm{Hg}$ load to the James Creek system impacts biota. Measurements of $\mathrm{Hg}_{\mathrm{T}}$ and $\mathrm{MMHg}$ in biota in conjunction with water and sediment mercury data limited by sampling deficiencies will fail to achieve this understanding, as will be more apparent after reading section 3.3 . 


\subsubsection{Geochemistry of James Creek water and OHE drainage}

The $\mathrm{pH}$ of James Creek and OHE drainage is buffered by bicarbonate, resulting in a narrow range of $\mathrm{pH} 8.2$ to 8.4 (Table 4). Chloride concentrations are similar among the tested waters and are lower than sulfate, $\mathrm{Mg}(\mathrm{II})$, and $\mathrm{Ca}(\mathrm{II})$. Thermodynamically calculated ionic strengths of all sampled waters were lower than expected, primarily due to ion pairing of $\mathrm{Mg}^{2+}$ and $\mathrm{Ca}^{2+}$ with sulfate (20 to 30 percent of $\mathrm{Mg}$ (II) and $\mathrm{Ca}$ (II) is in the form of $\mathrm{MgSO}_{4}$ and $\mathrm{CaSO}_{4}$; complete results, including other ion pairs, are provided in Appendix 1). These model results emphasize the importance of taking ion pairing into account when interpreting indirect measurements of ionic strength (e.g., conductivity). Magnesium and calcium are nearly saturated with respect to calcite $\left(\mathrm{CaCO}_{3}\right)$ and magnesite $\left(\mathrm{MgCO}_{3}\right)$ in James Creek (Table 7), which is consistent with observations of efflorescent salts on dry sediments. Sources of sulfate to James Creek include oxidation of pyrite in mine workings, tailings, and waste rock along the tributary, the spring at the OHE, and weathering of native soil. The sulfate concentration in James Creek near the confluence with Tributary 1 was elevated for a fresh water [70 to $100 \mathrm{mg} / \mathrm{L}$ (0.7 to $1 \mathrm{mM})$; Table 4], in part due to drainage from Tributary 1 , which contained $130 \mathrm{mg} / \mathrm{L}(1.4 \mathrm{mM})$.

Fe(III)-(hydr)oxide colloids are common in many tributaries of James Creek and its upper reaches. These colloids are formed by the oxidation of ferrous iron dissolved from iron-sulfide minerals (presumably pyrite) associated with the volcanic sandstone and silica-carbonate alterred serpentinite veins that were mined. Infiltration of water into mined hillsides and the availability of oxygen through open adits promotes pyrite oxidation. Open adits likely yield the highest quantity of colloid-bearing water, but there are also seeps near collapsed adits from which ironrich water flows, according to our recent observations at the OHE and other mines in the region. Precipitation of $\mathrm{Fe}(\mathrm{Al}, \mathrm{Si})$-(hydr)oxides under low-temperature conditions results in small particle size and high specific surface area (i.e., surface area normalized by volume). As a result, these metals may be reactive under organic-rich or anaerobic conditions and should therefore not be considered inert.

Dissolved iron and aluminum concentrations are low in James Creek ( $<50$ to $100 \mu \mathrm{g} / \mathrm{L} \mathrm{Fe}$ and 10 to $20 \mu \mathrm{g} / \mathrm{L} \mathrm{Al}$; Table 5), which is consistent with the oxidized and alkaline $\mathrm{pH}$ that characterize the portion of James Creek sampled (these conditions usually favor the formation of Al,Fe(III)(hydr)oxides). Samples containing detectable dissolved iron appear to be supersaturated with respect to iron (hydr)oxides including hematite and goethite, based on thermodynamic calculations (Table 7). This supersaturation suggests that either most of the iron is present as filter-passing $(<0.45 \mu \mathrm{m})$ colloids - a widely documented occurrence (e.g., Zanker et al., 2003) - or that some unmeasured and unmodeled factors are causing the dissolution of Fe(III), conceivably including organic complexation (Stumm, 1995) and photoreduction (Waite and Morel, 1984). Dissolved silica is relatively abundant in James Creek (20 to $30 \mathrm{mg} / \mathrm{L}$ ), despite several Si-bearing minerals (clay minerals and potassium-feldspar) being thermodynamically supersaturated (Table 7 and Appendix 1). Metals and metalloids (collectively referred using the shorthand metal(loid)s), including aluminum and silicon, readily coprecipitate with $\mathrm{Fe}$ (III). The affect of silica is unclear, although it may partially inhibit the precipitation and reduce the specific surface area of Fe(III)-(hydr)oxides (Doelsch et al., 2001). An unstudied constituent that may be present in colloids is sulfur, which is especially abundant near adits where sulfur in pyrite is oxidized. White-yellow flocs have been observed, sometimes in close association with orange (presumably Fe(III)-rich) flocs but have not yet been characterized. We speculate that 
these flocs consist of appreciable amounts of elemental sulfur-formed either by abiotic (dissolved oxygen) or biological (e.g., bacterium Beggiatoa) oxidation of sulfide-and hydroxysulfates such as jarosite, which can exist with goethite (FeOOH) (Stoffregen et al., 2000).

On the basis of prior research in controlled laboratory systems and a variety of field-based studies metal-(hydr)oxides sorb metal(loid)s (for reviews, see Brown and Parks, 2001; Brown and Sturchio, 2002), and so we expect that metal(loid)s such as $\mathrm{Hg}(\mathrm{II}), \mathrm{As}(\mathrm{V}), \mathrm{Cr}(\mathrm{VI})$, and $\mathrm{Ni}-$ for which concern has been expressed-are transported as sorption complexes with Fe(III)(hydr)oxide colloids. With the exception of iron, the differences between dissolved (filtered) and unfiltered metal(loid) concentrations were negligible. The fate of a portion of these metal(loid) contaminants may be affected by the stability of $\mathrm{Fe}$ (III)-(hydr)oxide (including its coprecipitates).

Table 4. Temperature, $\mathrm{pH}$, alkalinity, and select anions. All concentration units are $\mathrm{mg} / \mathrm{L}$, except ionic strength, which is reported in molar units. Nitrate was not detected $(<0.2 \mathrm{mg} / \mathrm{L})$ in any sample.

\begin{tabular}{|c|c|c|c|c|c|c|c|c|c|}
\hline \multirow[b]{2}{*}{ Sample } & \multirow[b]{2}{*}{$\begin{array}{c}\text { Temperature } \\
{ }^{\circ} \mathrm{C}\end{array}$} & \multirow[b]{2}{*}{$\mathrm{pH}$} & \multirow[b]{2}{*}{$\begin{array}{c}\text { Specific } \\
\text { Conduct } \\
\text {-ivity } \\
(\mu \mathrm{S} / \mathrm{cm})\end{array}$} & \multirow[b]{2}{*}{$\begin{array}{c}\text { Alkalinity, } \\
\text { mg/L as } \\
\mathrm{CaCO}_{3}\end{array}$} & \multirow[b]{2}{*}{$\mathrm{HCO}_{3}^{-(1,2)}$} & \multicolumn{3}{|c|}{ Anions } & \multirow[b]{2}{*}{$\begin{array}{l}\text { Ionic strength } \\
\qquad(\mathrm{mol} / \mathrm{L})^{(1)}\end{array}$} \\
\hline & & & & & & $\mathrm{Cl}^{-}$ & $\mathrm{F}^{-}$ & $\mathrm{SO}_{4}{ }^{2-}$ & \\
\hline 04JC1 & 14 & 8.4 & 410 & 114 & 66 & 5 & 0.2 & 95 & 0.006 \\
\hline 04JC2 & 16 & 8.2 & 450 & 168 & 98 & 5.1 & 0.2 & 68 & 0.007 \\
\hline 04JC3 & 14 & 8.2 & 410 & 118 & 69 & 5.1 & 0.2 & 94 & 0.006 \\
\hline 04OHE1 & 19 & 8.3 & 210 & 431 & & 4.5 & 0.3 & 130 & 0.013 \\
\hline
\end{tabular}

Note: (1) Calculated from all available aqueous constituents using a thermodynamic model (section 2.4). (2) Minor fractions of $\mathrm{CO}_{3}{ }^{2-}$ and $\mathrm{H}_{2} \mathrm{CO}_{3}{ }^{*}$ are also likely present (Appendix 1).

Table 5. Elemental composition of filtered $(<0.45 \mu \mathrm{m})$ water. ICP-MS results. All units are $\mu \mathrm{g} / \mathrm{L}$ (microgram per liter) unless otherwise noted. Data highlighted in yellow were used to evaluate saturation indices of selected minerals (Table 7).

\begin{tabular}{|c|c|c|c|c|c|c|c|c|c|c|c|c|c|c|c|}
\hline Sample & $\mathrm{Al}$ & $\mathrm{Ba}$ & $\begin{array}{c}\mathrm{Ca} \\
\mathrm{mg} / \mathrm{L}\end{array}$ & $\mathrm{Ce}$ & Co & $\mathrm{Cr}$ & Cs & $\mathrm{Cu}$ & $\mathrm{Eu}$ & $\mathrm{Fe}$ & $\begin{array}{c}\mathrm{K} \\
\mathrm{mg} / \mathrm{L}\end{array}$ & $\mathrm{La}$ & $\mathrm{Li}$ & $\begin{array}{c}\mathrm{Mg} \\
\mathrm{mg} / \mathrm{L}\end{array}$ & Mn \\
\hline 04JC1-B & 15 & 33 & 14 & nd & 7.6 & 1.5 & 0.06 & $\mathrm{Nd}$ & nd & 82 & 1.8 & nd & 3.6 & 44 & 66 \\
\hline 04JC2-B & 17 & 45 & 36 & nd & 0.16 & 1.0 & nd & 0.56 & nd & nd & 1.9 & 0.01 & 6 & 35 & 1.1 \\
\hline 04JC3-B & 20 & 32 & 15 & 0.01 & 5.0 & 1.0 & 0.05 & nd & nd & 110 & 1.8 & 0.01 & 3.7 & 43 & 45 \\
\hline 04OHE1-B & 14 & 140 & 47 & nd & 0.09 & 1.1 & 0.11 & 0.73 & 0.01 & nd & 2.5 & nd & 68 & 110 & 2.3 \\
\hline Sample & $\begin{array}{c}\mathrm{Na} \\
\mathrm{mg} / \mathrm{L}\end{array}$ & $\mathrm{Nd}$ & $\mathrm{Ni}$ & $\begin{array}{c}\mathrm{P} \\
\mathrm{mg} / \mathrm{L}\end{array}$ & $\mathrm{Rb}$ & Sc & $\begin{array}{c}\mathrm{SiO}_{2} \\
\mathrm{mg} / \mathrm{L}\end{array}$ & $\begin{array}{c}\mathrm{SO}_{4} \\
\mathrm{mg} / \mathrm{L}\end{array}$ & $\mathrm{Sr}$ & $\mathrm{Ti}$ & U & V & Y & $\mathrm{Yb}$ & $\mathrm{Zn}$ \\
\hline 04JC1-B & 5.5 & & 440 & & 5.3 & 2.7 & 30 & 95 & 140 & 1 & 0.11 & & 0.04 & 0.01 & 1.8 \\
\hline 04JC2-B & 7.8 & 0.02 & 1.4 & 0.02 & 0.59 & 1.6 & 17 & 79 & 260 & 0.7 & 0.71 & 0.7 & 0.04 & & 5.2 \\
\hline 04JC3-B & 5.6 & 0.02 & 350 & & 4.9 & 2.6 & 27 & 99 & 150 & 1.2 & 0.14 & 0.5 & 0.03 & & 5.3 \\
\hline 04OHE1-B & 14 & & 1.7 & & 2.8 & 1.9 & 17 & 120 & 450 & 1.2 & 0.48 & & 0.01 & & 3.2 \\
\hline
\end{tabular}

Notes: (1) The following elements were not detected (detection limits in $\mu \mathrm{g} / \mathrm{L}$ are in parentheses): $\mathrm{Ag}$ $(<3)$, As $(<1)$, Be $(<0.05)$, Bi $(<0.2)$, Cd (<0.02), Dy $(<0.005)$, $\mathrm{Er}(<0.005)$, Ga $(<0.05)$, Gd $(<0.005)$, Ge $(<0.05)$, $\mathrm{Ho}(<0.005)$, Lu (<0.1), Mo $(<2), \mathrm{Nb}(<0.2), \mathrm{Pb}(<0.05), \operatorname{Pr}(<0.01), \mathrm{Sb}(<0.3), \mathrm{Se}(<1), \mathrm{Sm}(<0.01)$, $\mathrm{Ta}(<0.02), \mathrm{Tb}(<0.005)$, Th (<0.2), $\mathrm{Tl}(<0.1), \mathrm{W}(0.5), \mathrm{Zr}(<0.2)$.

(2) nd = not detected: $\mathrm{Ce}(<0.01), \mathrm{Cr}(<1)$, Cs $(<0.02), \mathrm{Cu}(<0.5), \mathrm{Eu}(<0.005), \mathrm{Fe}(<50), \mathrm{Ge}(<0.05), \mathrm{La}$ $(<0.01), \mathrm{Nd}(<0.01), \mathrm{P}(<0.01), \mathrm{Pb}(<0.05), \operatorname{Pr}(<0.01), \mathrm{Sm}(<0.01), \mathrm{V}(<0.5), \mathrm{Yb}(<0.005)$. 
Table 6. Elemental composition of unfiltered water. ICP-MS results. All units are $\mu \mathrm{g} / \mathrm{L}$ (microgram per liter) unless otherwise noted. See Table 5 for detection limits of undetected elements (denoted with an "nd").

\begin{tabular}{|c|c|c|c|c|c|c|c|c|c|c|c|c|c|c|c|c|c|c|c|}
\hline Sample & $\mathrm{Al}$ & $\mathrm{Ba}$ & $\begin{array}{c}\mathrm{Ca} \\
\mathrm{mg} / \mathrm{L}\end{array}$ & $\mathrm{Ce}$ & Co & $\mathrm{Cr}$ & Cs & $\mathrm{Cu}$ & Dy & $\mathrm{Er}$ & $\mathrm{Eu}$ & $\mathrm{Fe}$ & $\mathrm{Gd}$ & $\mathrm{Ge}$ & $\begin{array}{c}\mathrm{K} \\
\mathrm{mg} / \mathrm{L}\end{array}$ & $\mathrm{La}$ & $\mathrm{Li}$ & $\begin{array}{c}\mathrm{Mg} \\
\mathrm{mg} / \mathrm{L}\end{array}$ & \\
\hline 04JC1 & 17 & 34 & 15 & 0.08 & 8.5 & 2.0 & 0.06 & 0.51 & 0.01 & 0.01 & 0.01 & 1650 & 0.01 & nd & 2.0 & 0.07 & 3.8 & 43 & \\
\hline 04JC2 & 19 & 44 & 37 & 0.02 & 0.06 & 1.1 & nd & 0.60 & $\mathrm{Nd}$ & $\mathrm{Nd}$ & nd & $\mathrm{Nd}$ & 0.01 & nd & 2.0 & 0.02 & 6.3 & 35 & \\
\hline 04JC3 & 6.1 & 34 & 15 & 0.05 & 5.6 & 1.4 & 0.05 & 0.50 & 0.01 & 0.01 & 0.01 & 1060 & 0.02 & nd & 1.9 & 0.05 & 4 & 42 & \\
\hline 04OHE1 & 35 & 140 & 48 & 0.09 & 0.17 & nd & 0.14 & 0.94 & 0.01 & 0.01 & 0.01 & 160 & 0.01 & 0.05 & 2.5 & 0.04 & 67 & 105 & \\
\hline Sample & $\mathrm{Mn}$ & $\begin{array}{c}\mathrm{Na} \\
\mathrm{mg} / \mathrm{L}\end{array}$ & $\mathrm{Nd}$ & $\mathrm{Ni}$ & $\begin{array}{c}\mathrm{P} \\
\mathrm{mg} / \mathrm{L}\end{array}$ & $\mathrm{Pb}$ & $\operatorname{Pr}$ & $\mathrm{Rb}$ & Sc & $\begin{array}{l}\mathrm{SiO}_{2} \\
\mathrm{mg} / \mathrm{L}\end{array}$ & Sm & $\begin{array}{l}\mathrm{SO}_{4} \\
\mathrm{mg} / \mathrm{L}\end{array}$ & $\mathrm{Sr}$ & $\mathrm{Ti}$ & $U$ & V & Y & $\mathrm{Yb}$ & $\mathrm{Zn}$ \\
\hline 04JC1 & 72 & 5.3 & 0.06 & 480 & nd & nd & 0.01 & 5.1 & 2.7 & 31 & 0.02 & 95 & 140 & 1.1 & 0.12 & 0.7 & 0.12 & 0.01 & 7.5 \\
\hline 04JC2 & 1.3 & 7.6 & 0.02 & 1.4 & 0.02 & nd & nd & 0.56 & 1.7 & 17 & nd & 70 & 250 & 0.8 & 0.73 & 0.7 & 0.04 & $\mathrm{Nd}$ & 4.9 \\
\hline 04JC3 & 48 & 5.3 & 0.05 & 380 & nd & nd & 0.01 & 4.7 & 2.6 & 28 & 0.01 & 90 & 150 & 1 & 0.13 & 0.5 & 0.1 & 0.01 & 6.5 \\
\hline 04OHE1 & 22 & 13 & 0.04 & 1.7 & nd & 0.08 & 0.01 & 2.8 & 1.9 & 16 & nd & 120 & 450 & 1.7 & 0.48 & nd & 0.05 & nd & 16 \\
\hline
\end{tabular}


Table 7. Mineral saturation indices (S.I.) under a fixed atmospheric oxygen fugacity of 0.2 (approxmately $10 \mathrm{mg} / \mathrm{L}$ dissolved oxygen), based on the Geochemist's Workbench 'thermo.dat' database (http://www.geology.uiuc.edu/Hydrogeology/hydro_thermo.htm).

\begin{tabular}{|c|c|c|c|c|c|}
\hline \multirow{2}{*}{$\begin{array}{l}\text { Mineral } \\
\text { name }\end{array}$} & \multirow[t]{2}{*}{ Chemical formula } & \multicolumn{4}{|c|}{$\log Q / K^{1}$} \\
\hline & & JC1 & $\mathrm{JC2}$ & JC3 & $\mathrm{OHE}$ \\
\hline Birnessite & $\mathrm{Na}_{4} \mathrm{Mn}_{14} \mathrm{O}_{27} \cdot 9 \mathrm{H}_{2} \mathrm{O}$ & 62 & 45 & 58 & 48 \\
\hline Todorokite & $\left(\mathrm{Mn}^{2+}, \mathrm{Ca}, \mathrm{Mg}\right) \mathrm{Mn}_{3}^{4+}{ }_{3} \mathrm{O}_{7} \cdot \mathrm{H}_{2} \mathrm{O}$ & 54 & 39 & 51 & 42 \\
\hline Nontronite $^{2}$ & $\mathrm{Na}_{0.3} \mathrm{Fe}_{2}^{3+}(\mathrm{Si}, \mathrm{Al})_{4} \mathrm{O}_{10}(\mathrm{OH})_{2} \cdot \mathrm{nH}_{2} \mathrm{O}$ & $17.2-18.0$ & - & $17.5-18.2$ & - \\
\hline Hematite & $\mathrm{Fe}_{2} \mathrm{O}_{3}$ & 12.9 & & 13.2 & - \\
\hline Saponite $^{2}$ & $\begin{array}{c}(\mathrm{Mg}, \mathrm{Fe})_{3}(\mathrm{Al}, \mathrm{Si})_{4} \mathrm{O}_{10}(\mathrm{OH})_{2} \\
(0.5 \mathrm{Ca}, \mathrm{Na})_{0.3}-4 \mathrm{H}_{2} \mathrm{O}\end{array}$ & $5.7-6.4$ & $3.6-4.2$ & 5.0 & $5.1-6.5$ \\
\hline Goethite & $\alpha-\mathrm{FeOOH}$ & 6.0 & - & 6.1 & - \\
\hline Sepiolite & $\mathrm{Mg}_{4} \mathrm{Si}_{6} \mathrm{O}_{15}(\mathrm{OH})_{2} \cdot 6 \mathrm{H}_{2} \mathrm{O}$ & 3.5 & 0.3 & 1.7 & 3.2 \\
\hline Illite & $\mathrm{K}_{0.65} \mathrm{Al}_{2} \mathrm{Al}_{0.65} \mathrm{Si}_{3.35} \mathrm{O}_{10}(\mathrm{OH})_{2}$ & 3.4 & 2.7 & 3.8 & 1.8 \\
\hline K-feldspar & $\mathrm{KAISi}_{3} \mathrm{O}_{8}$ & 2.5 & 1.8 & 2.6 & 1.3 \\
\hline Kaolinite & $\mathrm{Al}_{2} \mathrm{Si}_{2} \mathrm{O}_{5}(\mathrm{OH})_{4}$ & 2.4 & 2.2 & 3.0 & 1.2 \\
\hline Ferrihydrite & $\mathrm{Fe}(\mathrm{OH})_{3}$ & 1.5 & - & 1.6 & - \\
\hline Dolomite & $\mathrm{CaMg}\left(\mathrm{CO}_{3}\right)_{2}$ & 1.4 & 1.7 & 1.0 & 2.1 \\
\hline Calcite & $\mathrm{CaCO}_{3}$ & -0.1 & 0.3 & -0.3 & 0.3 \\
\hline Gibbsite & $\mathrm{Al}(\mathrm{OH})_{3}$ & - & 0.3 & 0.4 & -0.2 \\
\hline Magnesite & $\mathrm{MgCO}_{3}$ & -0.2 & -0.3 & -0.4 & 0.1 \\
\hline Amorphous & Silica $\mathrm{SiO}_{2}$ & -0.5 & -0.7 & -0.5 & -0.8 \\
\hline Gypsum & $\mathrm{CaSO}_{4} \cdot 2 \mathrm{H}_{2} \mathrm{O}$ & -2.4 & -2.2 & -2.4 & -1.9 \\
\hline Brucite & $\mathrm{Mg}(\mathrm{OH})_{2}$ & -3.3 & -3.7 & -3.7 & -2.8 \\
\hline Epsomite & $\mathrm{MgSO}_{4} \cdot 7 \mathrm{H}_{2} \mathrm{O}$ & -4.3 & -4.5 & -4.3 & -3.9 \\
\hline
\end{tabular}

Notes: (1) $\mathrm{Q}=$ ion activity product; $\mathrm{K}=$ solubility product. $\log \mathrm{Q} / \mathrm{K}>0$ indicates the water was thermodynamically supersaturated with respect to the indicated mineral. However, log $Q / K>0$ does not indicate that the mineral was present or would necessarily precipitate (see text).

(2) Several cations, with Na-Nontronite the least supersaturate to Mg-Nontronite most supersaturated.

\subsection{Biota}

In the following three subsections, two different types of data are discussed: total mercury $\left(\mathrm{Hg}_{\mathrm{T}}\right)$ in invertebrates, frogs, and fish, and organic mercury in invertebrates, which is presumed to be and hereafter referred to as monomethyl mercury $(\mathrm{MMHg})$. Interpretation of $\mathrm{Hg}_{\mathrm{T}}$ in frogs and fish as an indicator of mercury reactivity, biouptake, or trophic transfer is limited, pending $\mathrm{MMHg}$ measuremens, by the possibility of these samples having contained cinnabar particles at the time of analysis. To minimize this limitation, the gastrointestinal tracts and external surfaces of all amphibians, where cinnabar most likely resides, were carefully flushed to remove any visible particles. However, extremely fine-grained, invisible, adhesive cinnabar particles and minerals to which inorganic $\mathrm{Hg}(\mathrm{II})$ was sorbed likely exist in the amphibians' habitats.

\subsubsection{Invertebrates $\left(\mathrm{Hg}_{\mathrm{T}}\right.$ and organic mercury)}

The relative contribution to the ecological impairment of James Creek by the OHE relative to other sources of mercury is not clear from invertebrate $\mathrm{Hg}_{\mathrm{T}}$ or organic mercury measurements. $\mathrm{Hg}_{\mathrm{T}}$ and $\mathrm{MMHg}$ was detected in all composite samples of invertebrates (Table 8). The geometric means for MMHg in invertebrates collected from James Creek upstream and downstream of the OHE were not appreciably different $(0.057 \mathrm{vs} .0 .060 \mu \mathrm{g} / \mathrm{g}$, with a t-test $P=0.39)$. $\mathrm{MMHg}$ concentrations in 12 samples of invertebrates collected from James Creek upstream of Tributary 
1 ranged from 0.03 to $0.1 \mu \mathrm{g} / \mathrm{g}$, while those in 12 samples collected downstream ranged from 0.03 to $0.3 \mu \mathrm{g} / \mathrm{g}$. Giant waterbugs collected in Spring and water striders collected in Autumn had the highest MMHg concentrations. Although sample quantity may be insufficient to compare mercury concentrations in invertebrates residing nearer to point sources of mercury with those farther downstream, invertebrate MMHg concentrations collected in Spring from Tributary 1 (approx. $0.1 \mu \mathrm{g} / \mathrm{g}$ ) and four samples collected from James Creek at the lower Corona Mine adit drainage (Figs. 1 and 10) in Autumn (0.09 to $0.2 \mu \mathrm{g} / \mathrm{g}$ ) were higher than those observed downstream (location JC3).

Average (geometric mean) MMHg concentrations in several invertebrate taxa collected from the James Creek watershed locations, summarized in Table 8 and Figures 15 and 16, were generally higher than those measured at a Bear River watershed 'baseline' station where there are no known point sources of mercury (Alpers et al., 2005). Specifically, dragonflies and water striders contained approximately three times as much MMHg ( $0.07 v s .0 .02 \mu \mathrm{g} / \mathrm{g}$ and $0.09 v s .0 .04 \mu \mathrm{g} / \mathrm{g}$, respectively), dobsonflies were 30 percent higher $(0.05 v s .0 .04 \mu \mathrm{g} / \mathrm{g})$, while beetles and predaceous stoneflies contained similar concentrations $(0.12 v s .0 .11 \mu \mathrm{g} / \mathrm{g}$ and $0.05 \mu \mathrm{g} / \mathrm{g}$, respectively).

Like other fresh water and marine ecosystems, where mercury in invertebrates has been found to consist of both inorganic and methyl mercury (Berzas Nevado et al., 2003; Faganeli et al., 2003), 40 percent (16 of 39) of predatory insect samples had greater than 50 percent mercury as organic mercury (presumably $\mathrm{MMHg}$; \$2.3.3). The mean $\mathrm{MMHg} / \mathrm{Hg}_{\mathrm{T}}$ proportion was 40 percent $(1 \sigma=30$ percent; Table 8), consisting of the following average proportions per taxon: dragonflies (20 percent), dobsonflies (25 percent), predaceous stoneflies (30 percent), predaceous diving beetles (40 percent), giant waterbugs (50 percent), backswimmers (60 percent), and water striders ( 80 percent). Compared to a gold mine-impacted ecosystem, the mean $\mathrm{MMHg} / \mathrm{Hg}_{\mathrm{T}}$ proportion in predatory insects collected from the OHE area was approximately half [cf. 1999-2001 study of Greenhorn Creek, Nevada County, CA, where $\mathrm{MMHg} / \mathrm{Hg}_{\mathrm{T}}$ averaged 75 percent $(1 \sigma=20$ percent); (Alpers et al., 2005)].

The low proportions of MMHg measured in invertebrates in James Creek and the presence of cinnabar in the creek (Fig. 14) suggest that some invertebrates may have anomolously high mercury concentrations as a result of cinnabar contamination. For example, one dragonfly larva contained $30 \mu \mathrm{g} / \mathrm{g}$ (ww) $\mathrm{Hg}_{\mathrm{T}}$, but only $0.06 \mu \mathrm{g} / \mathrm{g}$ (ww) MMHg, or 0.20 percent. Unlike this and other benthic invertebrates collected, water striders, whose exoskeletons should have been more thoroughly cleaned of particles and which do not feed in sediments, yielded the highest measured $\mathrm{MMHg} / \mathrm{Hg}_{\mathrm{T}}$ ratios since they likely were least contaminated by cinnabar. The current invertebrate data set is similar to that of a 1998 study by Slotton and Ayers (1999), which showed a similar range of $\mathrm{Hg}_{\mathrm{T}}$ concentrations and a subset of anomalously high $\mathrm{Hg}_{\mathrm{T}}$ concentrations that are likely due to cinnabar contamination. Other sources of inorganic mercury could be through consumption of phytoplankton and zooplankton, both of which can acquire and excrete dissolved inorganic and methyl mercury from water on relatively short time scales (Pickhardt and Fisher, 2007; Pickhardt et al., 2005; Tsui and Wang, 2004). Therefore, a rigorous assessment of ecological impairment in mercury mine-impacted ecosystems should include methyl mercury measurements in addition to $\mathrm{Hg}_{\mathrm{T}}$, as was performed for invertebrates. The following discussion of invertebrates focuses on methyl mercury concentrations. 
Table 8. Mercury and methlymercury in invertebrates collected from James Creek and the Oat Hill Extension Mine. ww = wet weight.

\begin{tabular}{|c|c|c|c|c|c|c|c|c|c|c|c|}
\hline Site & $\begin{array}{l}\text { Site } \\
\text { Code }\end{array}$ & Date & Order & Family & Number & $\begin{array}{c}\text { Mass } \\
(\mathrm{g})\end{array}$ & $\begin{array}{l}\text { Average } \\
\text { Mass (g) }\end{array}$ & $\begin{array}{c}\mathrm{Hg} \\
(\mathrm{ug} / \mathrm{g}) \\
\mathrm{ww} \\
\end{array}$ & $\begin{array}{l}\mathrm{MeHg} \\
(\mathrm{ug} / \mathrm{g}) \\
\mathrm{ww} \\
\end{array}$ & $\begin{array}{l}\text { percent } \\
\text { liquid }\end{array}$ & $\stackrel{\%}{\%}$ \\
\hline \multirow{10}{*}{$\begin{array}{l}\text { James Creek upstream of } \\
\text { Oat Hill Extension Mine } \\
\text { drainage }\end{array}$} & \multirow{10}{*}{$\mathrm{JC} 1$} & \multirow{10}{*}{$5 / 20 / 2004$} & Odonata & Aeshnidae & 3 & 0.92 & 0.31 & 0.77 & 0.063 & 80 & 8 \\
\hline & & & Hemiptera & Gerridae & 25 & 1.66 & 0.07 & 0.088 & 0.088 & 65 & 100 \\
\hline & & & Odonata & Gomphidae & 20 & 2.36 & 0.12 & 2.006 & 0.09 & 75 & 5 \\
\hline & & & Odonata & Gomphidae & 20 & 1.22 & 0.06 & 0.499 & 0.093 & 77 & 19 \\
\hline & & & Plecoptera & Perlidae & 10 & 1.99 & 0.2 & 0.155 & 0.034 & 77 & 22 \\
\hline & & & Plecoptera & Perlidae & 20 & 2.32 & 0.12 & 0.064 & 0.035 & 80 & 56 \\
\hline & & & Odonata & Aeshnidae & 1 & 0.46 & 0.46 & 32.1 & 0.058 & 78 & 0 \\
\hline & & & Hemiptera & Belostomatidae & 2 & 3.19 & 1.6 & 0.445 & 0.277 & 72 & 62 \\
\hline & & & Hemiptera & Gerridae & 24 & 1.59 & 0.07 & 0.097 & 0.096 & 66 & 99 \\
\hline & & & Plecoptera & Perlidae & 11 & 1.35 & 0.12 & 1.35 & 0.061 & 78 & 5 \\
\hline \multirow{3}{*}{$\begin{array}{l}\text { Oat Hill Extension wetland } \\
\text { area }\end{array}$} & \multirow{3}{*}{ OHE1 } & \multirow{3}{*}{$5 / 20 / 2004$} & Odonata & Cordulegastridae & 3 & 1.81 & 0.6 & 0.97 & 0.142 & 80 & 15 \\
\hline & & & Coleoptera & Dytiscidae & 30 & 1.89 & 0.06 & 13.5 & 0.064 & 51 & 1 \\
\hline & & & Hemiptera & Gerridae & 25 & 1.6 & 0.06 & 0.20 & 0.18 & 69 & 90 \\
\hline \multirow{4}{*}{$\begin{array}{l}\text { Oat Hill Extension drainage } \\
\text { near James Creek }\end{array}$} & \multirow{4}{*}{$\mathrm{JC2}$} & \multirow{4}{*}{$5 / 20 / 2004$} & Odonata & Cordulegastridae & 1 & 1 & 1 & 0.132 & 0.074 & 78 & 57 \\
\hline & & & Megaloptera & Corydalidae & 4 & 0.9 & 0.23 & 0.346 & 0.064 & 81 & 19 \\
\hline & & & Hemiptera & Gerridae & 25 & 1.79 & 0.07 & 0.103 & 0.079 & 67 & 76 \\
\hline & & & Hemiptera & Gerridae & 25 & 1.5 & 0.06 & 0.172 & 0.127 & 65 & 74 \\
\hline \multirow{2}{*}{$\begin{array}{l}\text { Lower Corona Mine- } \\
\text { Downstream }\end{array}$} & \multirow{2}{*}{ CRND } & \multirow{22}{*}{$10 / 29 / 2004$} & Hemiptera & Gerridae & 8 & 0.88 & 0.11 & 0.173 & 0.102 & 77 & 59 \\
\hline & & & Hemiptera & Notonectidae & 17 & 1.79 & 0.11 & 0.253 & 0.155 & 62 & 61 \\
\hline \multirow{2}{*}{$\begin{array}{l}\text { Lower Corona Mine- } \\
\text { Upstream }\end{array}$} & \multirow{2}{*}{ CRNU } & & Coleoptera & Dytiscidae & 16 & 0.66 & 0.04 & 0.161 & 0.09 & $N C^{a}$ & 56 \\
\hline & & & Coleoptera & Dytiscidae & 20 & 0.71 & 0.04 & 0.156 & 0.105 & $\mathrm{NC}$ & 67 \\
\hline \multirow{6}{*}{$\begin{array}{l}\text { James Creek upstream Oat } \\
\text { Hill Mine Drain }\end{array}$} & \multirow{6}{*}{$\mathrm{JC} 1$} & & Odonata & Aeshnidae & 8 & 1.18 & 0.15 & 0.06 & 0.025 & 82 & 41 \\
\hline & & & Megaloptera & Corydalidae & 3 & 0.93 & 0.31 & 0.141 & 0.042 & NC & 30 \\
\hline & & & Hemiptera & Gerridae & 25 & 1.14 & 0.05 & 0.135 & 0.117 & 53 & 87 \\
\hline & & & Odonata & Gomphidae & 11 & 2.5 & 0.23 & 0.347 & 0.042 & 78 & 12 \\
\hline & & & Odonata & Gomphidae & 11 & 2.54 & 0.23 & 14.4 & 0.074 & 79 & 1 \\
\hline & & & Plecoptera & Perlidae & 10 & 1.01 & 0.1 & 0.111 & 0.058 & $\mathrm{NC}$ & 52 \\
\hline \multirow{8}{*}{$\begin{array}{l}\text { James Creek downstream } \\
\text { Oat Hill Extension } \\
\text { Drain drainage }\end{array}$} & \multirow{8}{*}{ JC3 } & & Odonata & Aeshnidae & 7 & 1.17 & 0.17 & 0.091 & 0.048 & 82 & 53 \\
\hline & & & Hemiptera & Belostomatidae & 2 & 2.4 & 1.2 & 0.128 & 0.058 & 80 & 46 \\
\hline & & & Hemiptera & Belostomatidae & 2 & 2.66 & 1.33 & 0.19 & 0.069 & 77 & 36 \\
\hline & & & Odonata & Cordulegastridae & 1 & 1.19 & 1.19 & 0.216 & 0.033 & 85 & 15 \\
\hline & & & Hemiptera & Gerridae & 25 & 1.1 & 0.04 & 0.086 & 0.042 & 71 & 49 \\
\hline & & & Hemiptera & Gerridae & 25 & 1.04 & 0.04 & 0.097 & 0.058 & 68 & 60 \\
\hline & & & Odonata & Gomphidae & 7 & 1.6 & 0.23 & 0.201 & 0.051 & 80 & 25 \\
\hline & & & Plecoptera & Perlidae & 10 & 1.01 & 0.1 & 0.525 & 0.065 & 78 & 12 \\
\hline \multirow{4}{*}{$\begin{array}{l}\text { Oat Hill Extension wetland } \\
\text { area }\end{array}$} & \multirow{4}{*}{ OHE1 } & & Odonata & Aeshnidae & 4 & 1.07 & 0.27 & 4.427 & 0.09 & NC & 2 \\
\hline & & & Odonata & Cordulegastridae & 1 & 0.63 & 0.63 & 9.606 & 0.213 & NC & 2 \\
\hline & & & Coleoptera & Dytiscidae & 20 & 1.1 & 0.06 & 0.477 & 0.199 & $\mathrm{NC}$ & 42 \\
\hline & & & Coleoptera & Dytiscidae & 29 & 1.01 & 0.03 & 0.469 & 0.193 & $\mathrm{NC}$ & 41 \\
\hline
\end{tabular}


$\mathrm{MMHg}$ concentrations in invertebrates from the wetland area near OHE (OHE1) suggest that the sediments there produce methyl mercury that is taken up by lower trophic level organisms. Too few samples of invertebrates were collected to statistically compare biouptake of MMHg among sites. Seasonal (Spring vs. Autumn) comparisons are also not meaningful, because different taxa were collected in each season. However, $\mathrm{MMHg}$ concentrations in certain taxa at certain sites are noteworthy. The most contaminated invertebrates were from the OHE1 location (Table 8 and Figs. 14 and 15), where MMHg concentrations in seven samples of invertebrates ranged from 0.06 to $0.22 \mu \mathrm{g} / \mathrm{g} \mathrm{MMHg}$, five of which exceeded $0.14 \mu \mathrm{g} / \mathrm{g} \mathrm{MMHg}$ (Table 8). Of the taxa available at OHE1, dragonflies, water striders, and diving beetles were found to have the highest concentrations of $\mathrm{MMHg}$ (all approximately $0.2 \mu \mathrm{g} / \mathrm{g} \mathrm{ww}$, on average) of all the samples collected from the study area. These results demonstrate that MMHg produced in sediments can be taken up by local invertebrates, potentially providing a link between mercury methylation and trophic transfer to higher level organisms.

\subsubsection{Frogs $\left(\mathrm{Hg}_{\mathrm{T}}\right)$}

As is the case for invertebrate data, the ecological impact of the OHE in addition to other sources of mercury to James Creek is not clear from frog $\mathrm{Hg}_{\mathrm{T}}$ measurements. Five Foothill Yellowlegged frogs were collected on May 20 and two more on October 29; all were analyzed for $\mathrm{Hg}_{\mathrm{T}}$ (Table 9). Average concentrations of $\mathrm{Hg}_{\mathrm{T}}$ in frogs from James Creek were similar upstream (0.18 $\mu \mathrm{g} / \mathrm{g})$ and downstream $(0.15 \mu \mathrm{g} / \mathrm{g})$ of OHE drainage and at the lower Corona Mine adit drainage $(0.14 \mu \mathrm{g} / \mathrm{g})$.

$\mathrm{Hg}_{\mathrm{T}}$ in foothill yellow-legged frogs collected from the James Creek study area, ranging from 0.1 to $0.6 \mu \mathrm{g} / \mathrm{g} \mathrm{Hg}$ (Table 9), was on average twice that of values in an extensive database compiled from studies throughout Northern California ${ }^{6}(0.2$ vs. $0.1 \mu \mathrm{g} / \mathrm{g} \mathrm{Hg}$ ), with the highest concentration observed at the wetland area of the OHE in Autumn.

Frogs may be susceptible to trophic transfer of $\mathrm{MMHg}$ from invertebrates at this location, on the basis of relatively high $\mathrm{Hg}_{\mathrm{T}}$ in one frog $(0.6 \mu \mathrm{g} / \mathrm{g}$, approximately 40 times higher than the ten lowest frog recoveries in the Northern California database) and $\mathrm{MMHg}$ in invertebrates at that location. The concentration of $\mathrm{Hg}_{\mathrm{T}}$ in this frog from the wetland area of the OHE was exceeded by only 16 of the 190 foothill yellow-legged frogs analyzed by the USGS to-date in Northern $\mathrm{CA}^{7}$. While these results suggest that $\mathrm{Hg}$ is accumulated in biota above the lowest trophic level in James Creek, further study is required to rule out their misinterpretation due to cinnabar contamination.

\subsubsection{Fish $\left(\mathrm{Hg}_{\mathrm{T}}\right)$}

Like invertebrates and frogs, fish mercury results do not clearly indicate that the OHE site is responsible for ecological impairment of biota in addition to that from other sources of mercury to James Creek. A number of factors could limit the use of fish data for this assessement, including the close proximity of the sampling locations. The fish are more mobile than invertebrates and could have resided upstream and downstream of Tributary $1 . \mathrm{Hg}_{\mathrm{T}}$

\footnotetext{
${ }^{6}$ Foothill yellow-legged frogs have been collected in various studies in Northern California and analyzed for Hg since 1997. During that period, 190 frogs were analyzed from seven major watersheds, including Cache Creek in the Coast Range, the Bear-Yuba Watershed in the Sierras, the Trinity River, and Upper Clear Creek, including Whiskeytown National Recreation Area (R. Hothem unpubl. data).

${ }^{7}$ These 16 frogs were collected from the Cache Creek or Trinity River watersheds.
} 
Table 9. Mercury concentrations in Foothill Yellow-legged frogs (Rana boylii) collected from James Creek and Oat Hill Extension Mine.

\begin{tabular}{|c|c|c|c|c|c|c|c|c|c|}
\hline Site & $\begin{array}{l}\text { Site } \\
\text { code }\end{array}$ & Date & $\begin{array}{l}\text { Sample } \\
\text { code }\end{array}$ & $\begin{array}{l}\text { Total } \\
\text { Mass (g) }\end{array}$ & Age & Sex & $\begin{array}{l}\mathrm{Hg} \\
(\mu \mathrm{g} / \mathrm{g} \\
\mathrm{dw})\end{array}$ & $\begin{array}{l}\mathrm{Hg} \\
(\mu \mathrm{g} / \mathrm{g} \\
w w) \\
\end{array}$ & $\begin{array}{l}\text { Percent } \\
\text { liquid }\end{array}$ \\
\hline \multicolumn{10}{|l|}{ James Creek } \\
\hline $\begin{array}{l}\text { upstream Oat Hill } \\
\text { Extension }(\mathrm{OHE}) \\
\text { drainage }\end{array}$ & $\mathrm{JC} 1$ & $5 / 20 / 04$ & 1994 & 12.4 & Adult & Male & 0.77 & 0.18 & 76.0 \\
\hline James Creek & & & 1995 & 28.1 & Adult & Female & 0.93 & 0.20 & 78.0 \\
\hline downstream OHE & JC3 & $5 / 20 / 04$ & 1996 & 20.2 & Adult & Female & 0.59 & 0.13 & 80.2 \\
\hline drainage & & & 1997 & 15.3 & Adult & Male & 0.69 & 0.15 & 78.2 \\
\hline $\begin{array}{l}\text { OHE drainage } \\
\text { (Tributary 1) }\end{array}$ & OHED & 5/20/04 & 1998 & 3.06 & Juvenile & Female & 0.84 & 0.19 & 77.1 \\
\hline $\begin{array}{l}\text { Downstream of } \\
\text { lower Corona Mine } \\
\text { Adit }\end{array}$ & CRND & $10 / 29 / 04$ & 2027 & NA & Adult & Female & 0.58 & 0.14 & 76.5 \\
\hline $\begin{array}{l}\text { Oat Hill Extension } \\
\text { wetland area }\end{array}$ & OHE1 & $10 / 29 / 04$ & 2028 & NA & Juvenile & Unknown & 2.8 & 0.61 & 78.2 \\
\hline
\end{tabular}

concentrations in rainbow trout collected from James Creek up- and downstream of Tributary 1 ranged from 0.05 to $0.2 \mu \mathrm{g} / \mathrm{g}$ (geometric mean $0.1 \mu \mathrm{g} / \mathrm{g}$ ) and 0.1 to $0.3 \mu \mathrm{g} / \mathrm{g}$ (geometric mean $0.13 \mu \mathrm{g} / \mathrm{g}$ ), respectively. It is uncertain whether fillets from rainbow trout collected from James Creek would exceed the U.S. Environmental Protection Agency 2001 advisory level of $0.3 \mu \mathrm{g}$ of methyl mercury per gram of edible tissue (www.epa.gov/mercury), but whole body $\mathrm{Hg}_{\mathrm{T}}$ did not exceed $0.3 \mu \mathrm{g} / \mathrm{g}$ (Table 10; the highest recovery was $0.27 \mu \mathrm{g} / \mathrm{g}$ ). California roach upstream and downstream of OHE drainage ranged from 0.1 to $0.2 \mu \mathrm{g} / \mathrm{g} \mathrm{Hg}_{\mathrm{T}}$, (geometric mean $0.16 \mu \mathrm{g} / \mathrm{g}$ ). To protect the health of wildlife and humans, a target level of $0.05 \mu \mathrm{g}$-methyl $\mathrm{Hg} \mathrm{g}^{-1}$ whole body fish tissue have been set for small (less than four-inch total length) fish such as roach in another California mine-impacted subwatershed of Cache Creek, Harley Gulch (Cooke and Morris, 2005). While the roach collected in this study contain much higher levels of $\mathrm{Hg}_{\mathrm{T}}$, we are not sure what portion is methylated and therefore whether they pose an ecological risk as defined by Cooke and Morris (2005). Beckvar et al. (2005) concluded that $0.2 \mu \mathrm{g} \mathrm{Hg}_{\mathrm{T}} \mathrm{g}^{-1}$ whole-body fish tissue (on a wet weight basis) protects the health of juvenile and adult fish, but they did not consider the effect of mercury speciation, a necessary consideration given that the chemical steps required to render cinnabar reactive may be different than those required for different forms of inorganic $\mathrm{Hg}$ in other fresh water systems. Whether systems such as James Creek are unique in this regard is unknown. Therefore, broadly databased assessments of mercury toxicity or other bio-relevant behavior that do not explicitly take fundamental inorganic mercury reactivity into account should be applied with caution.

If enough mercury present in James Creek fish is cinnabar, $\mathrm{Hg}_{\mathrm{T}}$ concentrations exceeding 0.2 $\mu \mathrm{g} / \mathrm{g}$ may still be protective of their health. In addition to water and sediment (section 3.2.1), criteria for $\mathrm{Hg}_{\mathrm{T}}$ in predator $(0.2 \mu \mathrm{g} / \mathrm{g}$, presumably after Beckvar et al. (2005)) and prey $(0.03$ $\mu \mathrm{g} / \mathrm{g}$ ) fish have been proposed in the Tomales Bay watershed (Marshall, 2006). ${ }^{8}$ The effect of

\footnotetext{
${ }^{8}$ We do not know if Marshall and others were aware of speciation measurements of Kim et al. (2004) and Slowey (unpublished data transmitted by letter to Dyan Whyte and J. Marshall, SF Bay RWQCB), finding Hg dominant
} 
mercury speciation in that case was also not explicitly considered. Consequently, it would be dubious to conclude, based on eight percent of fish (3 out of 37) exceeding $0.2 \mu \mathrm{g} / \mathrm{g} \mathrm{Hg}_{\mathrm{T}}(\mathrm{Table}$ 10), that the aquatic ecology of James Creek is impaired. However, in light of the invertebrate results, the potential for ecological impairment is clearly evident and may manifest in other biota (e.g., piscivorous birds).

California roach had significantly higher $\mathrm{Hg}_{\mathrm{T}}$ on average than trout $(0.16 \mu \mathrm{g} / \mathrm{g}$ for 14 roach samples vs. $0.12 \mu \mathrm{g} / \mathrm{g}$ for 23 trout samples; test done with logged data), based on a $P$ value of 0.03 for a one-tailed $t$ test assuming equal variance for roach and trout $\mathrm{Hg}_{\mathrm{T}}$. Compared with the same species from other sites in Northern California, fish from James Creek were moderately contaminated with $\mathrm{Hg}^{9}$. Similar fish $\mathrm{Hg}_{\mathrm{T}}$ was measured in Spring 1998 in small and juvenile fish above the confluence of Tributary 1 with James Creek (Slotton and Ayers, 1999).

Fish $\mathrm{Hg}_{\mathrm{T}}$ concentrations in muscle tissue (on a wet weight basis) have been found to positively and non-linearly correlate to body length in other mine-impacted settings by Slotton et al. (2004), who were cognizant, unlike others (Jewett et al., 2003), of the potential for wide-ranging $\mathrm{Hg}$ concentrations to falsely imply this correlation. To linearize the relationship and normalize the errors as required in tests of significance, we $\log _{10}$ transformed our fish $\mathrm{Hg}_{\mathrm{T}}$ (ppm wet weight) and length $(\mathrm{mm})$ data prior to exploring their possible correlation. Because rainbow trout and California roach have different eating habits (trout are primarily insectivores, feeding on insects in drift and on the water surface, while roach are omnivores, eating algae and insects at or near sediment), we investigated each fish species data set separately. For the case of whole-body $\mathrm{Hg}_{\mathrm{T}}$ analyses of James Creek trout and roach collected during this study, $\log _{10}$ fish $\mathrm{Hg}_{\mathrm{T}}$ is correlated to total length (Fig. 17). However, the significance of these correlations is a matter of interpretation. Analysis of variance (ANOVA), which compares the variance of the $\log _{10} \operatorname{Hg}_{\mathrm{T}}$ data with the variance about the best-fit function, suggests that, 3.7 percent of the time, a correlation this large $\left(R^{2}=0.19\right)$ could happen by chance alone. ANOVA of roach data suggest the observed correlation $\left(R^{2}=0.46\right)$ could happen 9.4 percent of the time by chance alone. The likelihoods of improving estimation is the most interpretive part of these correlation results, and would depend on the policy implications and/or remedial expenditures. Given that the correlations are at best marginally significant with this small number of samples, validation of this putative correlation would require additional fish sampling.

For a single fish species, or among species of similar lifestyle and physiology, the presence or absence of a significant correlation between $\mathrm{Hg}$ and length is likely related, among other factors, to the proportion of $\mathrm{MMHg}$ to total $\mathrm{Hg}$. Since $\mathrm{MMHg}$ is retained more than inorganic $\mathrm{Hg}$, a stronger correlation with length will likely characterize fish containing higher proportions of MMHg. In the present study, we have no direct evidence of this proportion at this time. We would like to conclude whether the majority of $\mathrm{Hg}$ in the fish collected is methylated or not, because this distinction is critical to knowning whether the mercury in James Creek taken up by biota will likely be retained long enough to impact the ecology of the larger Putah Creek

cinnabar and metacinnabar in the source mine waste and apparent colloid transport of mercury to Gambonini Creek due to organic acids in hydrophytic plants, the processes of which was studied by Slowey et al. (2005a).

${ }^{9}$ Compared with 62 samples of California roach collected from Northern California since 1999 (R. Hothem, unpubl. data), which had a geometric mean of $0.14 \mu \mathrm{g} / \mathrm{g} \mathrm{Hg}$, the James Creek roach had a mean concentration of $0.16 \mu \mathrm{g} / \mathrm{g}$. A total of 406 samples of rainbow trout collected from Northern California since 1999 (R. Hothem, unpubl. data) had a geometric mean of $0.115 \mu \mathrm{g} / \mathrm{g} \mathrm{Hg}$, compared with $0.122 \mu \mathrm{g} / \mathrm{g}$ from James Creek. 

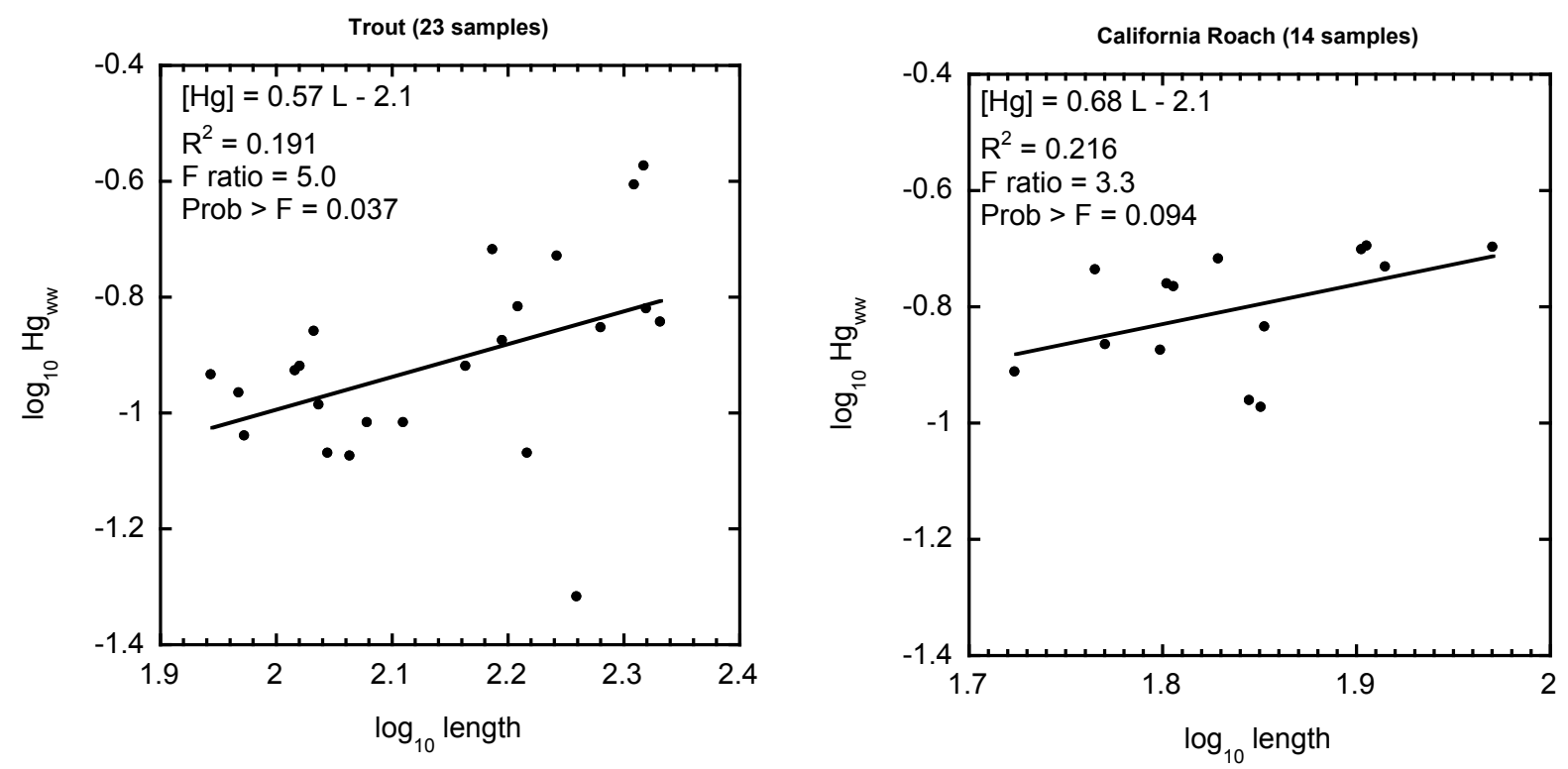

Figure 17. $\log _{10}$ transforms of $\mathrm{Hg}_{\mathrm{T}}$ (ppm, wet-weight basis) in Rainbow Trout and California Roach ([Hg]) compared to $\log _{10}$ transforms of total fish body length in $\mathrm{mm}(\mathrm{L})$. See text for an explanation as to why the data were log-transformed. The results of the regression analysis includes the squared correlation coefficient $R^{2}$ which denotes the proportion of variance of $\mathrm{Hg}$ accounted for by length and analysis of variance (ANOVA) significance tests in which the $F$ ratio statistic evaluates the probability that a relationship this strong could be made by chance, as is more fully explained in the text.

watershed, including Lake Berryessa. Given the policy implications of interpreting these and other biota data, we strongly discourage reliance on other studies (e.g., Bloom, 1992) as the basis for interpreting total mercury measurements as indicative of methyl mercury uptake. Appreciably different conditions at locations such as James Creek compared to systems that are more extensively studied (e.g., those receiving mercury primarily as a result of atmospheric deposition, not past mining) may have decisive implications.

To our knowledge, study of the proportion of methyl to total mercury in fish residing in cinnabar mine-impacted riverine systems is limited to two studies of the Yukon-Kuskokwim delta, Alaska (Gray et al., 2000; Jewett et al., 2003). Gray et al. (2000) sampled Arctic grayling (a low trophic-level fish) from Cinnabar Creek, a tributary of the Kuskokwim River known to contain cinnabar. The muscle tissue of three of these grayling were analyzed for both $\mathrm{Hg}_{\mathrm{T}}$ and $\mathrm{MMHg}$, finding 94 to 127 percent of mercury was methylated. Allowing for analytical errors evident from these results suggestst that most if not all mercury in muscle tissue of these fish species is methylated. In discussing these and the James Creek results, Gray noted there is a legitimate concern that an appreciable portion of mercury measured in whole-body samples of fish from a cinnabar-contaminated creek could be inorganic (pers. comm. March 28, 2007). At other locations along the Yukon and Kuskokwim Rivers, Jewett et al. (2003) found that, on average, 94 percent of mercury in pike muscle was methylated, but these fish were not collected near tributaries known to contain cinnabar (mercury in water or sediment was not measured). In conclusion, there currently is no strong basis on which to assume that the mercury measured in whole-body fish samples is mostly methylated. We recommend that, given the cost of MMHg 
analysis, a subset of fish samples be analyzed for both $\mathrm{Hg}_{\mathrm{T}}$ and $\mathrm{MMHg}$ and, when possible, to analyze muscle tissue in lieu of whole bodies.

\subsubsection{Trophic transfer of mercury}

On a sample-averaged basis at the two James Creek locations JC1 and JC3, frogs, roach, and trout all had higher levels of mercury than invertebrates (Fig. 18). Invertebrate MMHg was compared with upper trophic level biota to avoid bias due to the apparent ingestion by or adhesion of cinnabar to invertebrates. Estimation of bioaccumulation factors (BAFs) would be better supported by consistent use of $\mathrm{MMHg}$ data, since $\mathrm{Hg}_{\mathrm{T}}$ in these frogs and fish may include inorganic mercury resulting in overestimation of BAFs.

\section{Conclusions}

The OHE tailings are unusual in comparison to most mercury mine tailings because they were not heated in a retort or furnace. Processing of the ores through a gravity circuit to recover cinnabar concentrates resulted in tailings that should have considerably higher residual cinnabar and metal-sulfide mineals such as pyrite. The tailings, containing 600 to 1,000 ppm mercury, contaminate a tributary (Tributary 1) that drains the OHE area into James Creek. The 1,500 ppm mercury recovered from sediment in a drainage that transects the tailings pile (Drainage A) suggests that mercury-enriched sediment will be transported from the tailings during both base and high flows. However, there are other sources of mercury, including mercury-enriched (930 to $1,200 \mathrm{ppm}$ ) tailings above the OHE mine area from a dump near the USBLM property boundary (presumably from a past Oat Hill mining operation). Water from a spring located below the adit at the $\mathrm{OHE}$ had high $\mathrm{Hg}_{\mathrm{T}}(780 \mathrm{ng} / \mathrm{L})$, elevated sulfate $(130 \mathrm{mg} / \mathrm{L})$, and is saturated with respect to calcite and magnesite, both of which were observed in the spring sediment. This spring water flows into Tributary 1, which then flows into James Creek. Elevated concentration of mercury and sulfate in James Creek below the confluence with Tributary 1 may, therefore, partly result from drainage from this spring (Drainage B). Dispersion along this hydrological

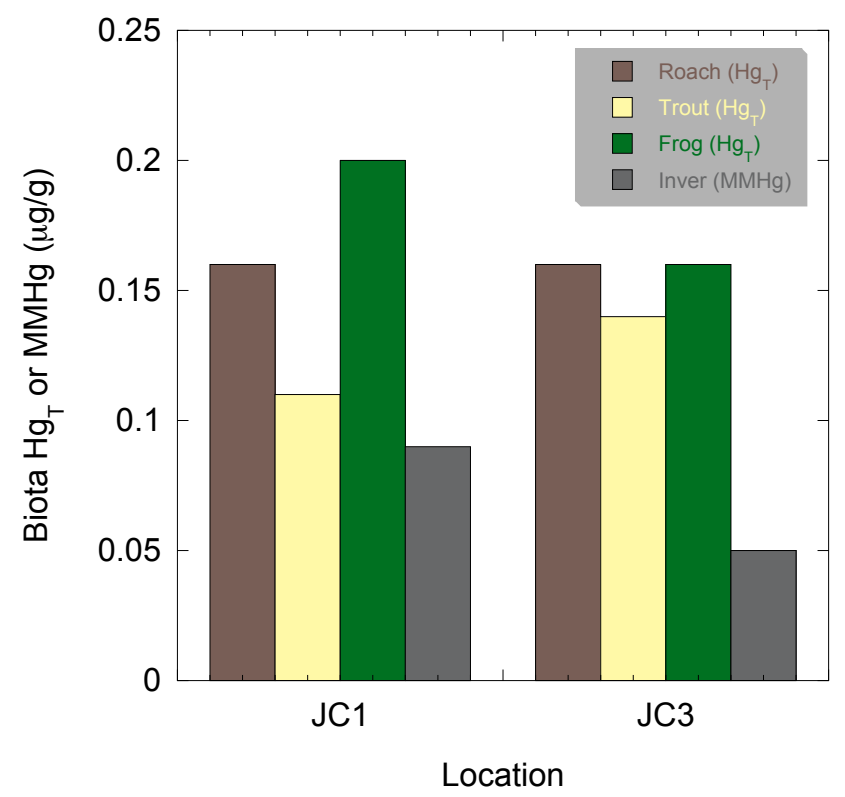
pathway is suggested by $\mathrm{Hg}$ and sulfate results (listed from Drainage B to Tributary 1 to James Creek): 780 to 14 to $7 \mathrm{ng} / \mathrm{L} \mathrm{Hg}_{\mathrm{T}}$; similarly, 130 to 70 to $90 \mathrm{mg} / \mathrm{L}$ sulfate.

Figure 18. Average concentrations of $\mathrm{MMHg}$ in invertebrates and $\mathrm{Hg}_{\mathrm{T}}$ in Foothill Yellow-legged frogs, California Roach, and Rainbow Trout sampled from James Creek locations JC1 and JC3 (Fig. 1). 
Table 10. Mercury concentrations in fish collected from James Creek on May 20, 2004.

\begin{tabular}{|c|c|c|c|c|c|c|c|c|}
\hline Site & $\begin{array}{c}\text { Site } \\
\text { Cod } \\
e\end{array}$ & $\begin{array}{c}\text { Unique Sample } \\
\text { Code }\end{array}$ & Common Name & Number & $\begin{array}{l}\text { Total Length } \\
\text { (ave. } \mathrm{mm} \text { ) }\end{array}$ & $\mathrm{Hg} \quad(\mathrm{ug} / \mathrm{g} \mathrm{dw})$ & $\begin{array}{l}\mathrm{Hg} \\
\text { (ug/g } \\
w w)\end{array}$ & $\begin{array}{l}\text { percent } \\
\text { Moisture }\end{array}$ \\
\hline \multirow{16}{*}{$\begin{array}{l}\text { James Creek upstream Oat Hill Extension } \\
\text { drainage (Tributary 1) }\end{array}$} & \multirow{15}{*}{$\mathrm{JC} 1$} & CR-JC1-001F & California roach & 4 & 93.5 & 0.890 & 0.200 & 77.5 \\
\hline & & CR-JC1-002F & California roach & 4 & 82.3 & 0.828 & 0.185 & 77.6 \\
\hline & & CR-JC1-003F & California roach & 1 & 80.0 & 0.891 & 0.198 & 77.8 \\
\hline & & CR-JC1-004F & California roach & 4 & 71.3 & 0.669 & 0.146 & 78.2 \\
\hline & & CR-JC1-005F & California roach & 1 & 70.0 & 0.496 & 0.109 & 78.1 \\
\hline & & CR-JC1-006F & California roach & 4 & 63.5 & 0.759 & 0.173 & 77.2 \\
\hline & & CR-JC1-007F & California roach & 1 & 53.0 & 0.538 & 0.122 & 77.3 \\
\hline & & CR-JC1-015F & Rainbow trout & 1 & 215.0 & 0.469 & 0.143 & 69.5 \\
\hline & & CR-JC1-016F & Rainbow trout & 1 & 191.0 & 0.483 & 0.140 & 71.0 \\
\hline & & CR-JC1-017F & Rainbow trout & 1 & 182.0 & 0.152 & 0.048 & 68.7 \\
\hline & & CR-JC1-018F & Rainbow trout & 1 & 175.0 & 0.849 & 0.186 & 78.1 \\
\hline & & CR-JC1-019F & Rainbow trout & 1 & 157.0 & 0.524 & 0.133 & 74.6 \\
\hline & & CR-JC1-020F & Rainbow trout & 1 & 111.0 & 0.376 & 0.085 & 77.3 \\
\hline & & CR-JC1-021F & Rainbow trout & 1 & 109.0 & 0.462 & 0.103 & 77.7 \\
\hline & & CR-JC1-022F & Rainbow trout & 1 & 108.0 & 0.610 & 0.138 & 77.4 \\
\hline & \multirow{22}{*}{$\mathrm{JC} 3$} & CR-JC1-023F & Rainbow trout & 1 & 104.0 & 0.513 & 0.118 & 77.0 \\
\hline \multirow{21}{*}{$\begin{array}{l}\text { James Creek downstream Oat Hill } \\
\text { Extension drainage (Tributary 1) }\end{array}$} & & CR-JC1-024F & Rainbow trout & 1 & 94.0 & 0.423 & 0.091 & 78.5 \\
\hline & & CR-JC3-008F & California roach & 4 & 80.5 & 0.869 & 0.201 & 76.9 \\
\hline & & CR-JC3-009F & California roach & 4 & 67.5 & 0.815 & 0.191 & 76.6 \\
\hline & & CR-JC3-010F & California roach & 1 & 71.0 & 0.455 & 0.106 & 76.6 \\
\hline & & CR-JC3-011F & California roach & 4 & 63.0 & 0.538 & 0.133 & 75.2 \\
\hline & & CR-JC3-012F & California roach & 1 & 64.0 & 0.845 & 0.171 & 79.8 \\
\hline & & CR-JC3-013F & California roach & 4 & 58.3 & 0.756 & 0.183 & 75.8 \\
\hline & & CR-JC3-014F & California roach & 1 & 59.0 & 0.548 & 0.136 & 75.1 \\
\hline & & CR-JC3-025F & Rainbow trout & 1 & 209.0 & 0.476 & 0.151 & 68.2 \\
\hline & & CR-JC3-026F & Rainbow trout & 1 & 208.0 & 1.140 & 0.266 & 76.7 \\
\hline & & CR-JC3-027F & Rainbow trout & 1 & 204.0 & 1.160 & 0.247 & 78.7 \\
\hline & & CR-JC3-028F & Rainbow trout & 1 & 165.0 & 0.302 & 0.085 & 71.7 \\
\hline & & CR-JC3-029F & Rainbow trout & 1 & 162.0 & 0.675 & 0.152 & 77.5 \\
\hline & & CR-JC3-030F & Rainbow trout & 1 & 154.0 & 0.855 & 0.191 & 77.7 \\
\hline & & CR-JC3-031F & Rainbow trout & 1 & 146.0 & 0.507 & 0.120 & 76.4 \\
\hline & & CR-JC3-032F & Rainbow trout & 1 & 129.0 & 0.397 & 0.096 & 75.8 \\
\hline & & CR-JC3-033F & Rainbow trout & 1 & 120.0 & 0.380 & 0.096 & 74.8 \\
\hline & & CR-JC3-034F & Rainbow trout & 1 & 116.0 & 0.346 & 0.084 & 75.7 \\
\hline & & CR-JC3-035F & Rainbow trout & 1 & 105.0 & 0.505 & 0.120 & 76.2 \\
\hline & & CR-JC3-036F & Rainbow trout & 1 & 93.0 & 0.449 & 0.108 & 75.9 \\
\hline & & CR-JC3-037F & Rainbow trout & 1 & 88.0 & 0.512 & 0.116 & 77.3 \\
\hline
\end{tabular}


Placer cinnabar has historically been mined from James Creek, and seasonal enrichment of the cinnabar in James Creek has been reported in at least one report (Yates and Hilpert, 1946), presumably due to erosion of mercury-enriched sediment from the Oat Hill and OHE mines during winter storm events. Panned concentrates containing appreciable amounts of cinnabar were obtained from James Creek both above and below the confluence with Tributary 1, indicating that significant sources of mercury-enriched sediment are released from both the Oat Hill $^{10}$ and OHE mine sites. A larger amount of cinnabar was apparent in the panned concentrate above Tributary 1, tentatively suggesting that the Oat Hill Mine site may be a more significant source of cinnabar than the OHE Mine to the nearest reach of James Creek (other mine sites may have more or less impact on James Creek as a whole).

High levels of mercury present in sediment and water at the OHE spring, Tributary 1, and James Creek did not result in correspondingly high concentrations of $\mathrm{MMHg}$ in the apparently aerobic water and sediment sampled. This finding is likely due to the stability of cinnabar in water and sediments containing low concentrations of organic matter and sulfide and/or degradation of MMHg. To better evaluate the methylation potential of the James Creek system and enhancement of this potential by nearby mine sites, additional sampling and analysis of sediments where MMHg production is more likely to occur should be performed. These locations include root-stabilized fluvial and riparian sediments and wetlands. Although localized production of $\mathrm{MMHg}$ may not yield appreciable $\mathrm{MMHg}$ concentrations in the bulk waters of James Creek, accumulation of MMHg in fish in mine-impacted waters can be facilitated by uptake of MMHg by benthic invertebrates followed by their consumption by bottom-feeding fish (Slotton et al., 2004).

While there is evidence from measurements of water, sediment, and biota that mercury from the OHE and other mines may be impairing the James Creek ecosystem, the measurements suggest that the degree of impairment is not commensurate with the extraordinary degree of mercury contamination present. Methyl mercury concentrations in flowing water and sediment from James Creek and the tributary that drains the OHE are relatively low, ranging from 0.04 to 0.08 $\mathrm{ng} / \mathrm{L}$, although these data should be interpreted with caution (see $\S 3.2$ ).

While the results of this investigation suggest that the OHE contributes inorganic mercury to James Creek, they do not indicate whether the OHE site is ecologically impairing biota in addition to impairment from other sources of mercury to James Creek, nor do they provide any indication of the relative importance of the OHE to the ecological impairment.

Acknowledgments. This field investigation was funded by the USBLM, who also granted access to study locations. We thank David Lawler (USBLM) for sampling assistance. Permission to collect biological specimens for study was kindly granted by the California Department of Fish and Game. Ion chromatography and alkalinity analyses were performed by USGS laboratories under the direction of Paul Lamothe. ICP-AES analyses were performed in USGS laboratories under the direction of Paul Briggs. R. Taylor of TERL and C. Davies of Brooks Rand conducted or oversaw the chemical analyses of biota. K. DeClercq and A. Meckstroth helped collect biota.

\footnotetext{
${ }^{10}$ See footnote 1, p. 2.
} 
Forthright and careful reviews by Roger Ashley and Steve Ludington (USGS) improved this report. AJS gratefully acknowledges the help of Donald Singer (USGS) with statistics.

\section{References}

Alpers, C. N., Hunerlach, M. P., May, J. T., Hothem, R. L., Taylor, H. E., Antweiler, R. C., DeWild, J. F., Lawler, D. A., 2005. Geochemical characterization of water, sediment, and biota affected by mercury contamination and acidic drainage from historical gold mining, Greenhorn Creek, Nevada County, California, 1999-2001. U.S. Geological Survey Scientific Investigations Report. 2004-525, 278 pp.

Banfield, J. F., Welch, S. A., Zhang, H. Z., Ebert, T. T., Penn, R. L., 2000. Aggregation-based crystal growth and microstructure development in natural iron oxyhydroxide biomineralization products. Science 289, 751-754.

Barrow, N. J., Cox, V. C., 1992. The Effects of pH and chloride concentration on mercury sorption 1. By goethite. J. Soil Sci. 43, 295-304.

Benoit, J. M., Gilmour, C. C., Heyes, A., Mason, R. P., Miller, C. L., 2003. Geochemical and biological controls over methylmercury production and degradation in aquatic ecosystems. In: Cai, Y., Braids, O. C. (Eds.), Biogeochemistry of Environmentally Important Trace Elements. 835 ACS Symposium Series Oxford University Press, Oxford. pp. 262-297.

Benoit, J. M., Gilmour, C. C., Mason, R. P., 2001. The influence of sulfide on solid-phase mercury bioavailability for methylation by pure cultures of Desulfobulbus propionicus (1pr3). Environ. Sci. Technol. 35, 127-132.

Berzas Nevado, J. J., Garcia Bermejo, L. F., Rodriguez Martin-Doimeadios, R. C., 2003. Distribution of mercury in the aquatic environment at Almaden, Spain. Environ. Pollut. 122, 261-271.

Bloom, N. S., 1992. On the Chemical Form of Mercury in Edible Fish and Marine Invertebrate Tissue. Can. J. Fish. Aquat. Sci. 49, 1010-1017.

Bloom, N. S., 1995. Mercury as a case study of ultra-clean sample handling and storage in aquatic trace metal research. Environmental Laboratory 3-4, 20-25.

Bloom, N. S., 2001. Solid Phase Hg Speciation and Incubation Studies in or Related to Mine-site Runoff in the Cache Creek Watershed (CA). Assessment of Ecological and Human Health Impacts of Mercury in the San Francisco Bay-Delta Watershed. 37 pp. California Bay Delta Authority, Sacramento.

Bloom, N. S., Crecelius, E. A., Fitzgerald, W. F., 1988. Determination of volatile mercury species at the picogram level by low temperature gas chromatography with cold vapor atomic fluorescence detection. Anal. Chim. Acta 208, 151-161.

Brown, G. E., Jr., Parks, G. A., 2001. Sorption of trace elements on mineral surfaces: Modern perspectives from spectroscopic studies, and comments on sorption in the marine environment. Int. Geol. Rev. 43, 963-1073.

Brown, G. E., Sturchio, N. C., 2002. An overview of synchrotron radiation applications to low temperature geochemistry and environmental science. In: Fenter, P. A., Rivers, M. L., Sturchio, N. C., Sutton, S. R. (Eds.), Applications of Synchrotron Radiation in LowTemperature Geochemistry and Environmental Sciences. Rev. Mineral. Geochem. 49 Mineralogical Society of America, Washington, DC. pp. 1-115. 
Conaway, C. H., Watson, E. B., Flanders, J., Flegal, A. R., 2004. Mercury deposition in a tidal marsh of south San Francisco Bay downstream of the historic New Almaden mining district, California. Mar. Chem. 90, 175-184.

Crock, J. G., 1996. Mercury. In: Sparks, D. L. (Ed.), Methods of Soil Analysis, Part 3. Chemical Methods. 5 Soil Science Society of America, Madison, WI. pp. 769-791.

Doelsch, E., Stone, W. E. E., Petit, S., Masion, A., Rose, J., Bottero, J. Y., Nahon, D., 2001. Speciation and crystal chemistry of $\mathrm{Fe}(\mathrm{III})$ chloride hydrolyzed in the presence of $\mathrm{SiO} 4$ ligands. 2. Characterization of Si-Fe aggregates by FTIR and Si-29 solid-state NMR. Langmuir 17, 1399-1405.

Ericksen, J. A., Gustin, M. S., Lindberg, S. E., Olund, S. D., Krabbenhoft, D. P., 2005. Assessing the potential for re-emission of mercury deposited in precipitation from arid soils using a stable isotope. Environ. Sci. Technol. 39, 8001-8007.

Faganeli, J., Horvat, M., Covelli, S., Fajon, V., Logar, M., Lipej, L., Cermelj, B., 2003. Mercury and methylmercury in the Gulf of Trieste (northern Adriatic Sea). Sci. Total Environ. 304, 315-326.

Fishman, M. J., Friedman, L. C., 1989. Ion Chromatography, Methods for Determination of Inorganic Substances in Water and Fluvial Sediments. Techniques of Water-Resources Investigations of the United States Geological Survey. U.S. Geological Survey, http://pubs.usgs.gov/twri/twri5-a1/pdf/twri_5-A1_b.pdf. pp. 38-43.

Fleming, E. J., Mack, E. E., Green, P. G., Nelson, D. C., 2006. Mercury methylation from unexpected sources: Molybdate-inhibited freshwater sediments and an iron-reducing bacterium. Appl. Environ. Microbiol. 72, 457-464.

Gilbert, B., Banfield, J. F., 2005. Molecular-scale processes involving nanoparticulate minerals in biogeochemical systems. In: Banfield, J., CerviniSilva, J., Nealson, K. (Eds.), Molecular Geomicrobiology. Reviews in Mineralogy \& Geochemistry. 59 Mineralogical Society of America and Geochemical Society, Virginia. pp. 109-155.

Gilmour, C. C., Henry, E. A., Mitchell, R., 1992. Sulfate stimulation of mercury methylation in freshwater sediments. Environ. Sci. Technol. 26, 2281-2287.

Gray, J., Theodorakos, P., Bailey, E., Turner, R., 2000. Distribution, speciation, and transport of mercury in stream-sediment, stream-water, and fish collected near abandoned mercury mines in southwestern Alaska, USA. Sci. Total Environ. 260, 21-33.

Gustin, M. S., Coolbaugh, M. F., Engle, M. A., Fitzgerald, B. C., Keislar, R. E., Lindberg, S. E., Nacht, D. M., Quashnick, J., Rytuba, J. J., Sladek, C., Zhang, H., Zehner, R. E., 2003. Atmospheric mercury emissions from mine wastes and surrounding geologically enriched terrains. Environ. Geol. 43, 339-351.

Gustin, M. S., Ericksen, J. A., Schorran, D. E., Johnson, D. W., Lindberg, S. E., Coleman, J. S., 2004. Application of controlled mesocosms for understanding mercury air-soil-plant exchange. Environ. Sci. Technol. 38, 6044-6050.

Helgeson, H. C., 1969. Thermodynamics of Hydrothermal Systems at Elevated Temperatures and Pressures. Am. J. Sci. 267, 729-804.

Horvat, M., Bloom, N. S., Liang, L., 1993a. A comparison of distillation with other current isolation methods for the determination of methyl mercury compounds in low level environmental samples, part 2, water. Anal. Chim. Acta 282, 153-168.

Horvat, M., Bloom, N. S., Liang, L., 1993b. Comparison of distillation with other current isolation methods for the determination of methyl mercury compounds in low level environmental samples: Part 1. Sediments. Anal. Chim. Acta 281, 135-152. 
Jay, J. A., Morel, F. M. M., Hemond, H. F., 2000. Mercury speciation in the presence of polysulfides. Environ. Sci. Technol. 34, 2196-2200.

Jay, J. A., Murray, K. J., Gilmour, C. C., Mason, R. P., Morel, F. M. M., Roberts, A. L., Hemond, H. F., 2002. Mercury methylation by Desulfovibrio desulfuricans ND132 in the presence of polysulfides. Appl. Environ. Microbiol. 68, 5741-5745.

Jewett, S. C., Zhang, X. M., Naidu, A. S., Kelley, J. J., Dasher, D., Duffy, L. K., 2003. Comparison of mercury and methylmercury in northern pike and Arctic grayling from western Alaska rivers. Chemosphere 50, 383-392.

Kappler, A., Straub, K. L., 2005. Geomicrobiological Cycling of Iron. In: Banfield, J. F., Cervini-Silva, J., Nealson, K. H. (Eds.), Molecular Geomicrobiology. Rev. Mineral. Geochem. 59 Mineralogical Society of American and Geochemical Society, Virginia. pp. 85-108.

Kerin, E. J., Gilmour, C. C., Roden, E., Suzuki, M. T., Coates, J. D., Mason, R. P., 2007. Mercury methylation by dissimilatory iron-reducing bacteria. Appl. Environ. Microbiol. 72, 7919-7921.

Kim, C. S., Rytuba, J. J., Brown, G. E., Jr., 2004. Geological and anthropogenic factors influencing mercury speciation in mine wastes: an EXAFS spectroscopy study. Appl. Geochem. 19, 379-393.

Lowry, G. V., Shaw, S., Kim, C. S., Rytuba, J. J., Brown, G. E., Jr., 2004. Particle-facilitated mercury transport from New Idria and Sulphur Bank mercury mine tailings: Column experiments and macroscopic, microscopic and spectroscopic analysis. Environ. Sci. Technol. 38, 5101-5111.

Merritt, K. A., Amirbahman, A., 2007. Mercury Mobilization in Estuarine Sediment Porewaters: A Diffusive Gel Time-Series Study. Environ. Sci. Technol. 41, 717-722.

Nordstrom, D. K., Southam, G., 1997. Geomicrobiology of sulfide mineral oxidation. In: Banfield, J. F., Nealson, K. H. (Eds.), Geomicrobiology: Interactions between Microbes and Minerals. Rev. Mineral. Geochem. 35 Mineralogical Society of America, Washington, D.C. pp. 361-390.

O'Leary, R. M., Hageman, P. L., Crock, J. G., 1996. Determination of mercury in water, geologic, and plant materials by continuous flow-cold vapor-atomic absorption spectrophotometry. In: Arbogast, B. F. (Ed.), Analytical methods for the Mineral Resource Surveys Program. Open File Report 96-525 U.S. Geological Survey, Denver. pp. $42-55$.

Paquette, K. E., Helz, G. R., 1997. Inorganic speciation of mercury in sulfidic waters: The importance of zero-valent sulfur. Environ. Sci. Technol. 31, 2148-2153.

Parker, J. L., Bloom, N. S., 2005. Preservation and storage techniques for low-level aqueous mercury speciation. Sci. Total Environ. 337, 253-263.

Pickhardt, P. C., Fisher, N. S., 2007. Accumulation of inorganic and methylmercury by freshwater phytoplankton in two contrasting water bodies. Environ. Sci. Technol. 41, 125131.

Pickhardt, P. C., Folt, C. L., Chen, C. Y., Klaue, B., Blum, J. D., 2005. Impacts of zooplankton composition and algal enrichment on the accumulation of mercury in an experimental freshwater food web. Sci. Total Environ. 339, 89-101.

Poulton, S. W., Krom, M., Raiswell, R., 2004. A revised scheme for the reactivity of iron (oxyhydr)oxide minerals towards dissolved sulfide. Geochim. Cosmochim. Acta 68, 37033715. 
Pyzik, A., Sommer, S., 1981. Sedimentary iron monosulfides: kinetics and mechanism of formation. Geochim. Cosmochim. Acta 45, 687-698.

Rickard, D., Morse, J. W., 2005. Acid volatile sulfide (AVS). Mar. Chem. 97, 141-197.

Rounds, S. A., 2006. Alkalinity and acid neutralizing capacity. In: Wilde, F. D. (Ed.), National field manual for the collection of water-quality data: U.S. Geological Survey Techniques of Water-Resources Investigations. U.S. Geological Survey. http://pubs.water.usgs.gov/twri9A.

Seeberg-Elverfeldt, J., Schluter, M., Feseker, T., Kolling, M., 2005. Rhizon sampling of porewaters near the sediment-water interface of aquatic systems. Limnol. Oceanogr. Methods 3, 361-371.

Sellers, P., Kelly, C. A., Rudd, J. W. M., MacHutchon, A. R., 1996. Photodegradation of methylmercury in lakes. Nature 380, 694-697.

Sigg, L., Black, F., Buffle, J., Cao, J., Cleven, R., Davison, W., Galceran, J., Gunkel, P., Kalis, E., Kistler, D., Martin, M., Noel, S., Nur, Y., Odzak, N., Puy, J., vanRiemsdijk, W., Temminghoff, E., Tercier-Waeber, M. L., Toepperwien, S., Town, R. M., Unsworth, E., Warnken, K. W., Weng, L., Xue, H., Zhang, H., 2006. Comparison of analytical techniques for dynamic trace metal speciation in natural freshwaters. Environ. Sci. Technol. 40, 19341941.

Slotton, D. G., Ayers, S. M., 1999. Pope Creek Watershed 1998 Biological Mercury Assessment. 45 pp. for Public Resource Associates, San Francisco, CA and Reno, NV.

Slotton, D. G., Ayers, S. M., Suchanek, T. H., Weyand, R. D., Liston, A. M., 2004. Mercury Bioaccumulation and Trophic Transfer in the Cache Creek Watershed of California in Relation to Diverse Aqueous Mercury Exposure Conditions. Assessment of Ecological and Human Health Impacts of Mercury in the San Francisco Bay-Delta Watershed. 74 pp. California Bay Delta Authority, Sacramento.

Slowey, A. J., Brown Jr., G. E., 2007. Transformations of mercury, iron, and sulfur during the reductive dissolution of iron oxyhydroxide by sulfide. Geochim. Cosmochim. Acta 71, 877894.

Slowey, A. J., Johnson, S. B., Rytuba, J. J., Brown, G. E., Jr., 2005a. Role of organic acids in promoting colloid transport of mercury from mine tailings. Environ. Sci. Technol. 39, 78697874.

Slowey, A. J., Rytuba, J. J., Brown, G. E., Jr., 2005b. Speciation of mercury and mode of transport from placer gold mine tailings. Environ. Sci. Technol. 39, 1547-1554.

Stoffregen, R. E., Alpers, C. N., Jambor, J. L., 2000. Alunite-jarosite crystallography, thermodynamics, and geochronology. In: Alpers, C. N., Jambor, J. L., Nordstrom, D. K. (Eds.), Sulfate Minerals: Crystallography, Geochemistry and Environmental Significance. Rev. Mineral. Geochem. 40 Mineralogical Society of America, Washington D.C. pp. 453479.

Stumm, W., 1995. The Inner-Sphere Surface Complex-A Key to Understanding Surface Reactivity, Aquatic Chemistry. Advances in Chemistry Series. 244 American Chemical Society, Columbus, OH. pp. 1-32.

Tsui, M. T. K., Wang, W.-X., 2004. Uptake and elimination routes of inorganic mercury and methylmercury in Daphnia magna. Environ. Sci. Technol. 38, 808-816.

United States Bureau of Mines, 1965. Mercury potential of the United States. Information Circular 8252. 
United States Environmental Protection Agency, 2002. Method 1631, Revision E: Mercury in Water by Oxidation, Purge and Trap, and Cold Vapor Atomic Fluorescence Spectrometry. Report 821-R-02-019, http://www.epa.gov/waterscience/methods/1631e.pdf.

Uthe, J. F., Solomon, J., Grift, B., 1972. Rapid semimicro method for the determination of methylmercury in fish tissue. J. Assoc. Official Anal. Chem. 55, 583-589.

Waite, T. D., Morel, F. M. M., 1984. Photoreductive dissolution of colloidal iron oxide: Effect of citrate. J. Colloid Interf. Sci. 102, 121-137.

Waples, J., Nagy, K. L., Aiken, G. R., Ryan, J. N., 2005. Dissolution of cinnabar (HgS) in the presence of natural organic matter. Geochim. Cosmochim. Acta 69, 1575-1588.

Whyte, D. C., Kirchner, J. W., 2000. Assessing water quality impacts and cleanup effectiveness in streams dominated by episodic mercury discharges. Sci. Total Environ. 260, 1-9.

Yates, R. G., Hilpert, L. S., 1946. Quicksilver deposits of the Eastern Mayacmas District, Lake and Napa Counties, California. California Journal of Mines and Geology Report XLII of the State Mineralogist, 231-286.

Zanker, H., Richter, W., Huttig, G., 2003. Scavenging and immobilization of trace contaminants by colloids in the waters of abandoned ore mines. Colloids Surfaces A: Physicochem. Eng. Aspects 217, 21-31. 


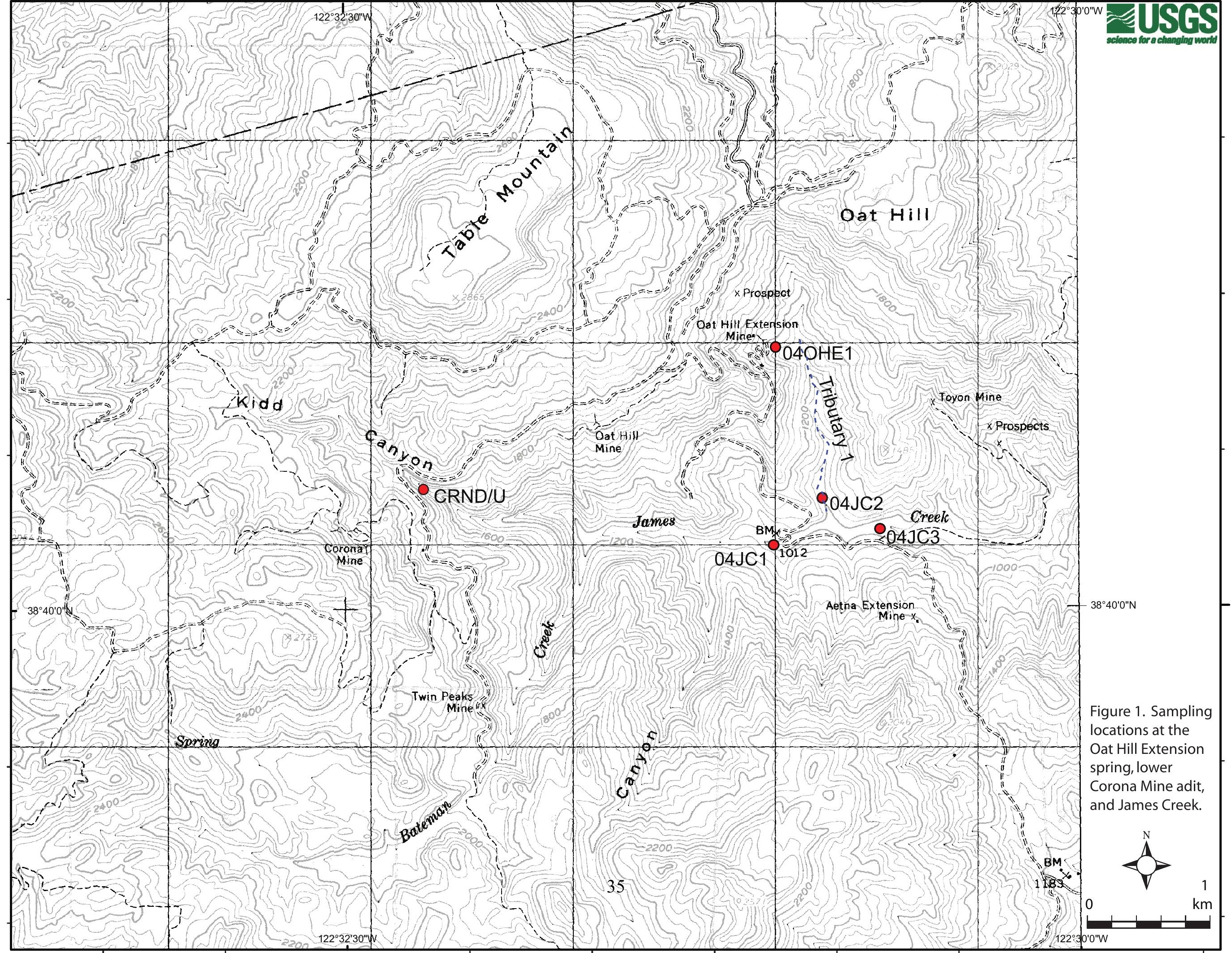




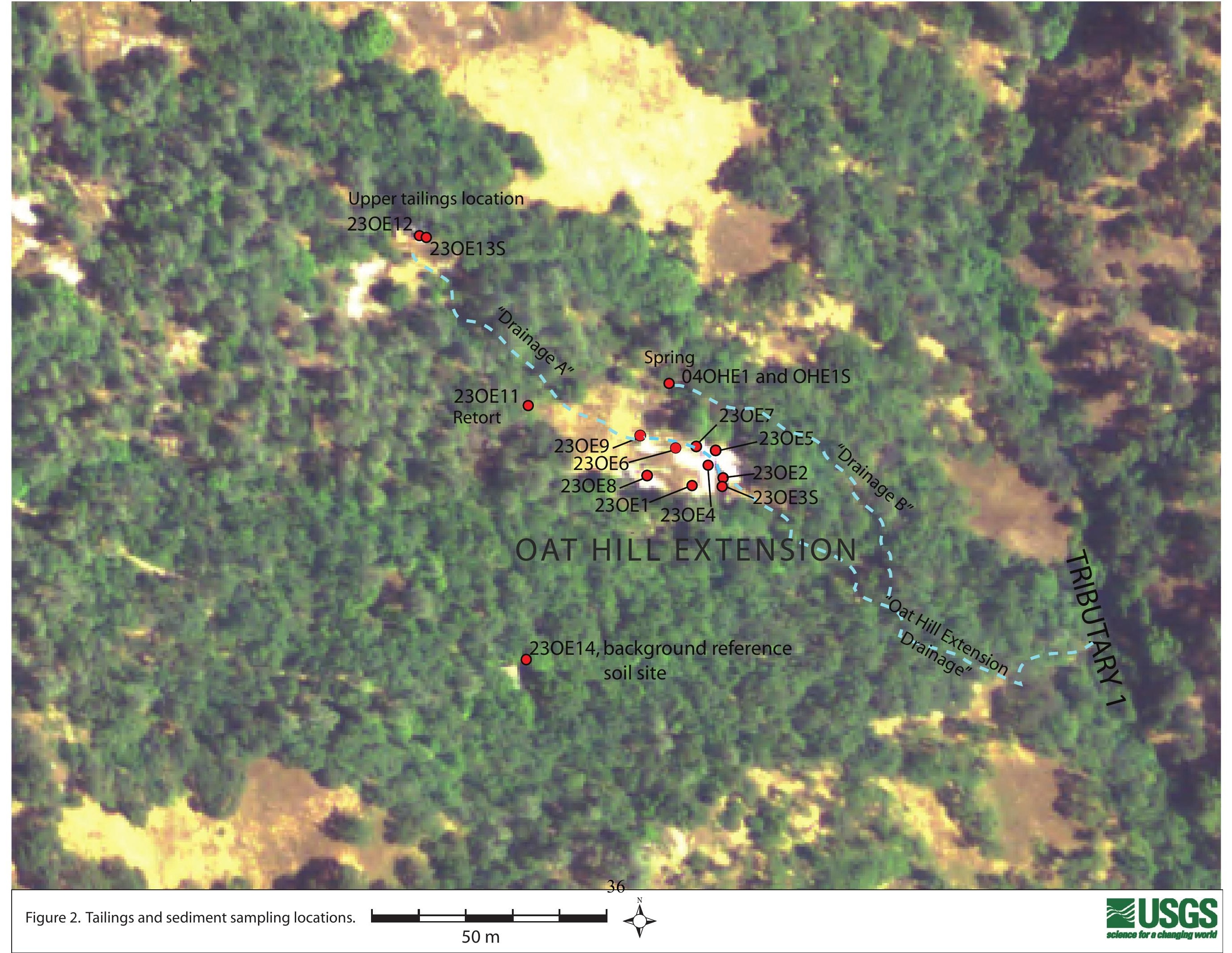




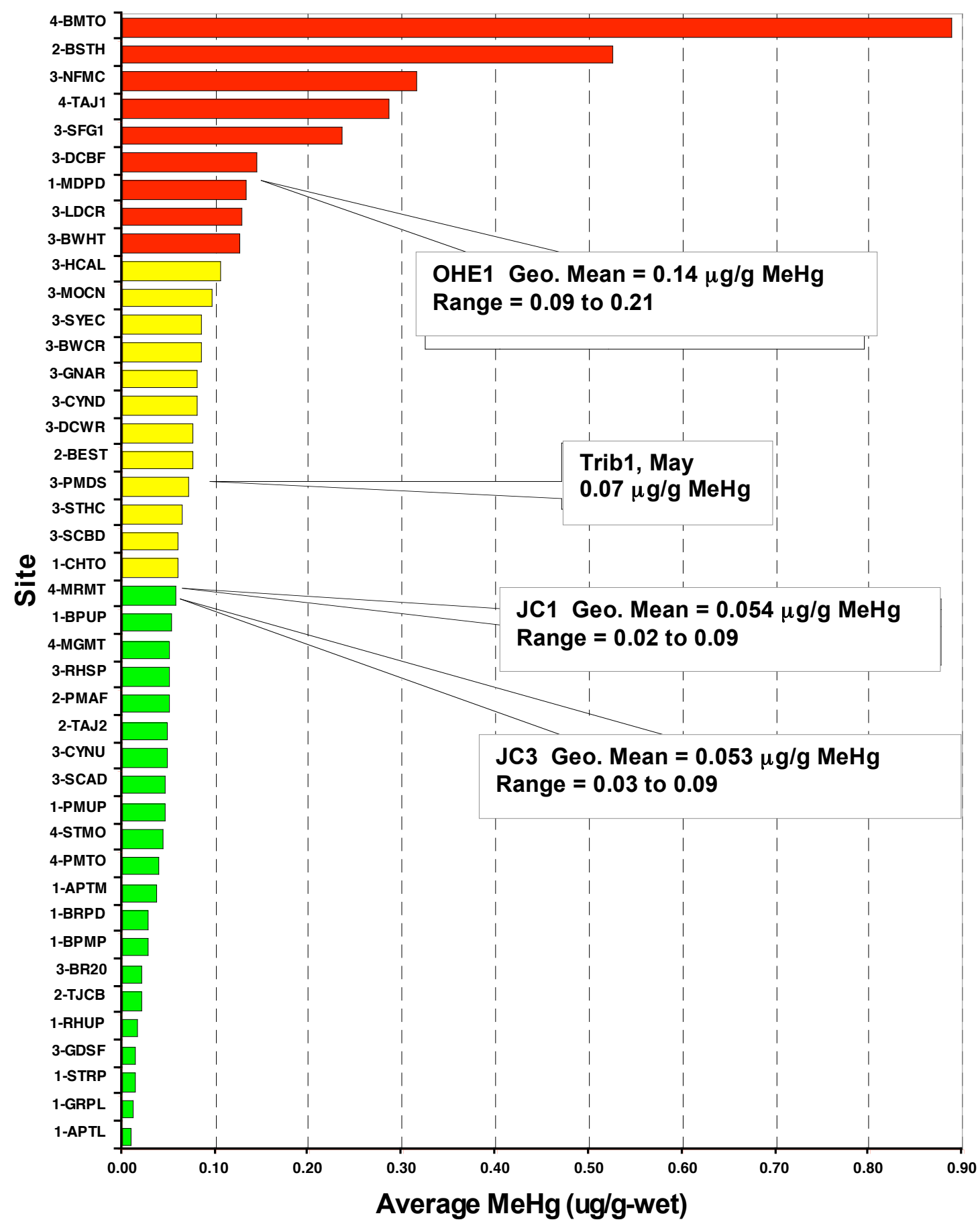

Figure 15. Average methylmercury concentration ( $\mu \mathrm{g} / \mathrm{g}$, wet wt.) in larval dragonflies (Odonata) from 42 Sierra Nevada sites, 1999-2002, compared with selected water striders from the Oat Hill/James Creek study area, 2004. Methyl mercury in Sierra dragonflies was considered high (red), medium (yellow), or low (green) based on a comparison with the median for all sites. High: > 2 times the median, Medium: < 2 times the median, but greater than the median, and Low: less than the median. 


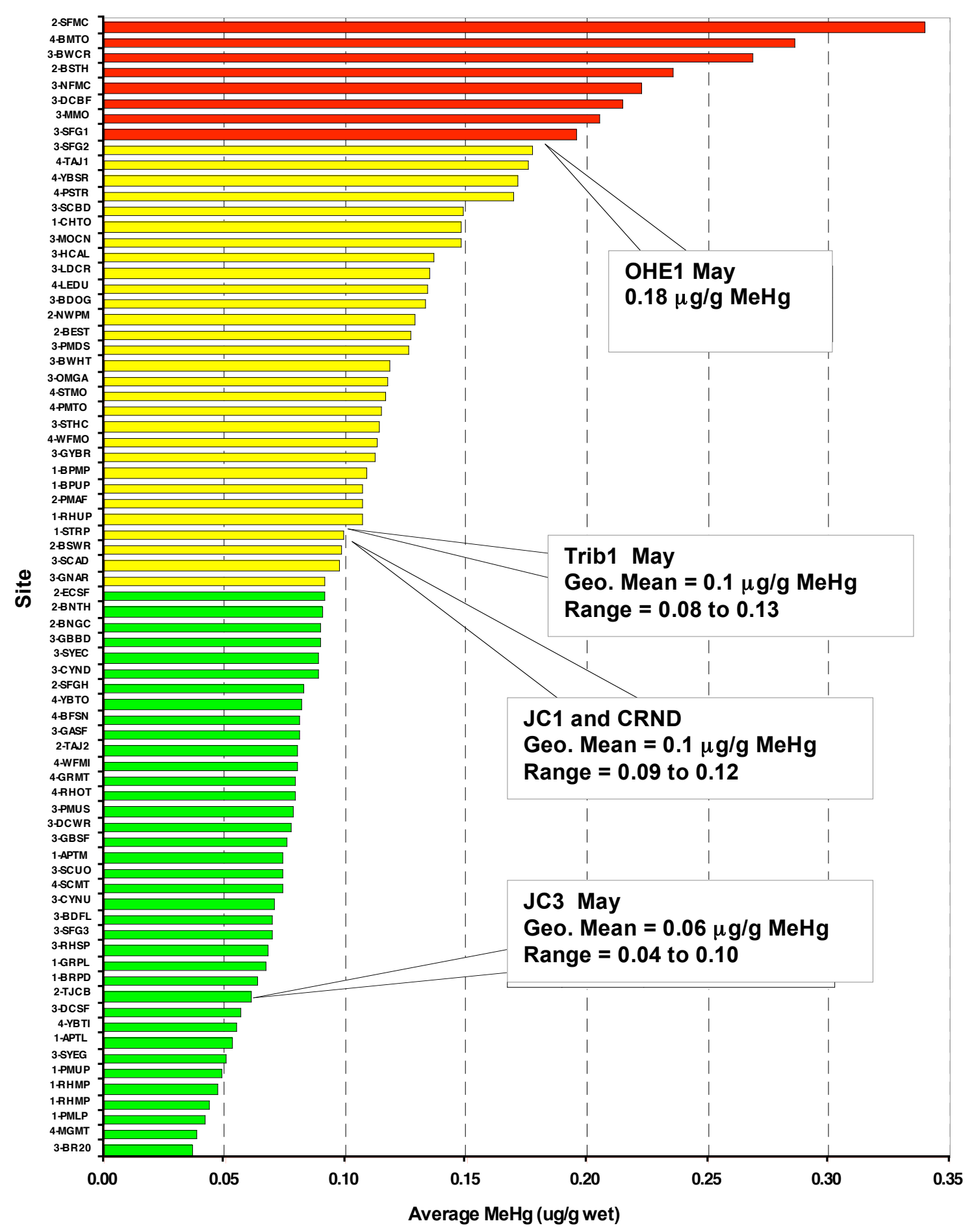

Figure 16. Average methylmercury concentration ( $\mu \mathrm{g} / \mathrm{g}$, wet wt.) in adult water striders (Gerridae) from 74 Sierra Nevada sites, 1999-2002, compared with selected water striders from the Oat Hill/James Creek study area, 2004. Methyl mercury in Sierra water striders was considered high (red), medium (yellow), or low (green) based on a comparison with the median for all sites. High: > 2 times the median, Medium: < 2 times the median, but greater than the median, and Low: less than the median. 
Table 2. Chemical analysis of tailings and sediments at the Oat Hill Extension site, and soil deemed as representing background concentrations.

\begin{tabular}{|c|c|c|c|c|c|c|c|c|c|c|c|c|c|c|c|c|c|c|c|c|c|c|c|c|}
\hline & Lat & Long & $\begin{array}{c}\mathrm{Hg} \\
\mathrm{ppm}\end{array}$ & $\begin{array}{c}\mathrm{Ag} \\
\mathrm{ppm}\end{array}$ & $\begin{array}{l}\mathrm{Al} \\
\% \\
\end{array}$ & $\begin{array}{c}\text { As } \\
\mathrm{ppm}\end{array}$ & $\begin{array}{c}\mathrm{Ba} \\
\mathrm{ppm}\end{array}$ & $\begin{array}{c}\mathrm{Be} \\
\mathrm{ppm}\end{array}$ & $\begin{array}{c}\mathrm{Bi} \\
\mathrm{ppm}\end{array}$ & $\begin{array}{l}\mathrm{Ca} \\
\%\end{array}$ & $\begin{array}{c}\mathrm{Cd} \\
\mathrm{ppm}\end{array}$ & $\begin{array}{c}\mathrm{Ce} \\
\mathrm{ppm}\end{array}$ & $\begin{array}{c}\text { Co } \\
\mathrm{ppm}\end{array}$ & $\begin{array}{c}\mathrm{Cr} \\
\mathrm{ppm}\end{array}$ & $\begin{array}{l}\text { Cs } \\
\text { ppm }\end{array}$ & $\begin{array}{c}\mathrm{Cu} \\
\mathrm{ppm}\end{array}$ & $\begin{array}{l}\mathrm{Fe} \\
\% \\
\end{array}$ & $\begin{array}{c}\mathrm{Ga} \\
\mathrm{ppm}\end{array}$ & $\begin{array}{c}\mathrm{Ge} \\
\mathrm{ppm}\end{array}$ & $\begin{array}{c}\mathrm{Hf} \\
\mathrm{ppm}\end{array}$ & $\begin{array}{c}\text { In } \\
\text { ppm }\end{array}$ & $\begin{array}{l}\mathrm{K} \\
\% \\
\end{array}$ & $\begin{array}{c}\text { La } \\
\text { ppm }\end{array}$ & $\begin{array}{c}\mathrm{Li} \\
\mathrm{ppm}\end{array}$ \\
\hline \multicolumn{25}{|c|}{ Lower Tailings Pile at the Oat Hill Extension Mine } \\
\hline 23-OE-1 & 38.67716 & 122.51748 & 767 & 0.17 & 6.4 & 5.2 & 750 & 1.4 & 0.2 & 1.8 & 0.2 & 44 & 16 & 91 & 5 & 36 & 3.9 & 14.0 & 0.3 & 1.5 & 0.03 & 1.6 & 22 & 32 \\
\hline 23-OE-2 & 38.67813 & 122.5174 & 599 & 0.16 & 6.1 & 6.1 & 750 & 1.1 & 0.2 & 2.0 & 0.2 & 45 & 16 & 61 & 4 & 42 & 4.9 & 13.2 & 0.3 & 1 & 0.04 & 1.5 & 23 & 31 \\
\hline 23-OE-4 & 38.67833 & 122.51745 & 827 & 0.16 & 6.1 & 3.2 & 700 & 1.3 & 0.1 & 1.9 & 0.1 & 48 & 15 & 92 & 4 & 32 & 4.3 & 13.3 & 0.3 & 1 & 0.04 & 1.5 & 24 & 31 \\
\hline 23-OE-5 & 38.67833 & 122.51745 & 998 & 0.18 & 6.6 & 3.3 & 800 & 1.4 & 0.1 & 2.0 & 0.2 & 56 & 16 & 58 & 4 & 37 & 4.9 & 14.4 & 0.4 & 1.1 & 0.04 & 1.6 & 28 & 33 \\
\hline 23-OE-6 & 38.67844 & 122.51781 & 891 & 0.15 & 5.9 & 4.4 & 720 & 1.2 & 0.1 & 2.0 & 0.2 & 48 & 16 & 96 & 4 & 38 & 4.5 & 13.0 & 0.3 & 1.1 & 0.03 & 1.5 & 24 & 29 \\
\hline $23-\mathrm{OE}-7$ & 38.6784 & 122.51772 & 430 & 0.16 & 5.6 & 1.9 & 710 & 1.4 & 0.1 & 2.5 & 0.2 & 53 & 17 & 56 & 4 & 40 & 5.8 & 12.5 & 0.3 & 1.2 & 0.03 & 1.4 & 27 & 32 \\
\hline 23-OE-8 & 38.67853 & 122.51758 & 830 & 0.15 & 5.5 & 0.2 & 610 & 1.1 & 0.1 & 1.9 & 0.2 & 49 & 14 & 87 & 4 & 31 & 4.9 & 12.0 & 0.3 & 1.4 & 0.03 & 1.3 & 25 & 34 \\
\hline 23-OE-9 & 38.6787 & 122.51777 & 731 & 0.17 & 7.2 & 5.2 & 840 & 1.5 & 0.2 & 2.0 & 0.2 & 46 & 18 & 57 & 5 & 48 & 4.9 & 15.4 & 0.3 & 1.5 & 0.05 & 1.8 & 23 & 39 \\
\hline 23-OE-10 & 38.67856 & 122.51746 & 403 & 0.1 & 5.1 & $<0.2$ & 790 & 0.6 & 0.0 & 19.8 & 0.1 & 21 & 20 & 220 & 1 & 18 & 2.4 & 9.8 & 0.3 & 1.8 & 0.04 & 0.3 & 12 & 32 \\
\hline \multicolumn{25}{|c|}{ Upper Tailings above Adit at the Oat Hill Extension Mine } \\
\hline 23-OE-12 & 38.6791 & 122.51866 & 1175 & 0.14 & 6.6 & 1.9 & 610 & 1.2 & 0.1 & 2.0 & 0.1 & 41 & 14 & 86 & 4 & 28 & 3.5 & 13.6 & 0.3 & 1.3 & 0.03 & 1.4 & 21 & 33 \\
\hline \multicolumn{25}{|c|}{ Sediments in Drainage A that transects the Oat Hill Extension Tailngs Pile } \\
\hline 23-OE-13! & 38.6791 & 122.51866 & 930 & 0.18 & 8.3 & 11.6 & 910 & 1.6 & 0.4 & 1.0 & 0.2 & 42 & 19 & 78 & 5 & 60 & 4.1 & 18.2 & 0.3 & 1.2 & 0.05 & 2.1 & 21 & 34 \\
\hline 23-OE-3S & 38.67813 & 122.5174 & 1495 & 0.18 & 7.5 & 9.3 & 880 & 1.2 & 0.2 & 1.2 & 0.2 & 44 & 21 & 73 & 4 & 63 & 4.7 & 16.5 & 0.3 & 1.1 & 0.06 & 1.9 & 22 & 31 \\
\hline \multicolumn{25}{|c|}{ Sample of retort brick at Oat Hill Extension Mine } \\
\hline 23-OE-11 & 38.67846 & 122.51814 & 5.21 & 0.15 & 8.6 & 5.6 & 750 & 1.3 & 0.1 & 1.7 & 0.1 & 41 & 19 & 138 & 4 & 44 & 5.2 & 18.9 & 0.2 & 1.4 & 0.06 & 1.8 & 24 & 32 \\
\hline \multicolumn{25}{|c|}{ Background soil sample at Oat Hill Extension Office Site } \\
\hline 23-OE-14 & 38.67752 & 122.51819 & 6.71 & 0.13 & 7.3 & 8 & 750 & 1.3 & 0.1 & 0.3 & 0.2 & 45 & 16 & 62 & 4 & 36 & 4.5 & 16.2 & 0.2 & 0.7 & 0.05 & 1.57 & 23 & 38 \\
\hline
\end{tabular}

\begin{tabular}{|c|c|c|c|c|c|c|c|c|c|c|c|}
\hline \multicolumn{12}{|c|}{ Screening criteria, in $\mathrm{mg} / \mathrm{kg}$ (ppm) } \\
\hline BLM Camper & 40 & & & 700 & & & 20 & & & & \\
\hline BLM Eco Risk & 1 & & & & & & 4 & & & & \\
\hline EPA PRG & 23 & & & 390 & & 76000 & 22 & & & 5400 & 150 \\
\hline 23-OE-1 & + & + & + & - & - & - & - & + & - & - & - \\
\hline 23-OE-2 & + & + & + & - & - & - & - & + & - & - & - \\
\hline 23-OE-4 & + & + & + & - & - & - & - & - & - & - & - \\
\hline 23-OE-5 & + & + & + & - & - & - & - & - & - & - & - \\
\hline 23-OE-6 & + & + & + & - & - & - & - & + & - & - & - \\
\hline 23-OE-7 & + & + & + & - & - & - & - & - & - & - & - \\
\hline 23-OE-8 & + & + & + & - & - & - & - & - & - & - & - \\
\hline 23-OE-9 & + & + & + & - & - & - & - & + & - & - & - \\
\hline 23-OE-10 & + & + & + & - & - & - & + & + & + & - & - \\
\hline 23-OE-12 & + & + & + & - & - & - & - & - & - & - & - \\
\hline 23-OE-3S & + & + & + & - & - & - & - & + & - & - & - \\
\hline 23-OE-13S & + & + & + & - & - & - & - & + & - & - & - \\
\hline 23-OE-11 & - & + & - & - & - & - & - & + & - & - & - \\
\hline 23-OE-14 & - & + & - & - & - & - & - & + & - & - & - \\
\hline
\end{tabular}
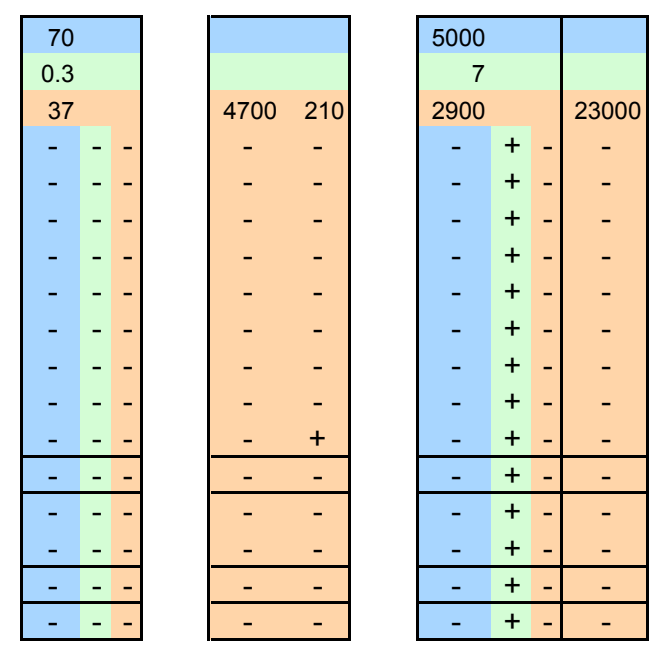

Note: Plus (+) signs indicate exceedance of the criterion listed, while minus (-) signs indicate that the element's concentration was below the criterion. 
Table 2 continued.

\begin{tabular}{|c|c|c|c|c|c|c|c|c|c|c|c|c|c|c|c|c|c|c|c|c|c|c|c|c|}
\hline & $\begin{array}{c}\mathrm{Mn} \\
\mathrm{ppm}\end{array}$ & $\begin{array}{c}\text { Mo } \\
\text { ppm }\end{array}$ & $\begin{array}{c}\mathrm{Na} \\
\% \\
\end{array}$ & $\begin{array}{c}\mathrm{Nb} \\
\mathrm{ppm}\end{array}$ & $\begin{array}{c}\mathrm{Ni} \\
\text { ppm }\end{array}$ & $\begin{array}{c}\mathrm{P} \\
\mathrm{ppm}\end{array}$ & $\begin{array}{c}\mathrm{Pb} \\
\mathrm{ppm}\end{array}$ & $\begin{array}{c}\mathrm{Rb} \\
\mathrm{ppm}\end{array}$ & $\begin{array}{l}\mathrm{S} \\
\% \\
\end{array}$ & $\begin{array}{c}\mathrm{Sb} \\
\mathrm{ppm}\end{array}$ & $\begin{array}{c}\mathrm{Se} \\
\mathrm{ppm}\end{array}$ & $\begin{array}{c}\text { Sn } \\
\text { ppm }\end{array}$ & $\begin{array}{c}\mathrm{Sr} \\
\mathrm{ppm}\end{array}$ & $\begin{array}{c}\mathrm{Ta} \\
\mathrm{ppm}\end{array}$ & $\begin{array}{c}\mathrm{Te} \\
\mathrm{ppm}\end{array}$ & $\begin{array}{c}\text { Th } \\
\text { ppm }\end{array}$ & $\begin{array}{l}\mathrm{Ti} \\
\% \\
\end{array}$ & $\begin{array}{c}\mathrm{Tl} \\
\mathrm{ppm}\end{array}$ & $\begin{array}{c}\mathrm{U} \\
\mathrm{ppm}\end{array}$ & $\begin{array}{c}\mathrm{V} \\
\mathrm{ppm}\end{array}$ & $\begin{array}{c}\text { W } \\
\text { ppm }\end{array}$ & $\begin{array}{c}\mathrm{Y} \\
\mathrm{ppm}\end{array}$ & $\begin{array}{c}\mathrm{Zn} \\
\mathrm{ppm}\end{array}$ & $\begin{array}{c}\mathrm{Zr} \\
\mathrm{ppm}\end{array}$ \\
\hline \multicolumn{25}{|c|}{ Lower Tailings Pile at the Oat Hill Extension Mine } \\
\hline 23-OE-1 & 576 & 0.96 & 0.5 & 7 & 55 & 630 & 15 & 64 & 0.23 & 1.06 & 2 & 2.5 & 235 & 0.3 & 0.05 & 8 & 0.3 & 0.5 & 1.9 & 119 & 2 & 15 & 92 & 36 \\
\hline 23-OE-2 & 741 & 0.95 & 0.4 & 5.5 & 57 & 680 & 15 & 60 & 0.08 & 1.28 & 1 & 2.2 & 252 & 0.2 & $<0.05$ & 7 & 0.3 & 0.4 & 1.9 & 126 & 1.2 & 16 & 110 & 26 \\
\hline 23-OE-4 & 668 & 0.79 & 0.4 & 5.3 & 54 & 660 & 14 & 59 & 0.11 & 1.02 & 1 & 2 & 217 & 0.2 & $<0.05$ & 6 & 0.3 & 0.4 & 2.1 & 122 & 1.1 & 16 & 105 & 28 \\
\hline 23-OE-5 & 713 & 0.85 & 0.6 & 5.4 & 61 & 870 & 14 & 62 & 0.17 & 0.93 & 1 & 2.1 & 464 & 0.2 & $<0.05$ & 7 & 0.3 & 0.4 & 2.1 & 128 & 1.4 & 19 & 108 & 35 \\
\hline 23-OE-6 & 644 & 0.87 & 0.5 & 5.5 & 62 & 660 & 15 & 58 & 0.12 & 0.91 & 2 & 1.7 & 223 & 0.2 & $<0.05$ & 7 & 0.3 & 0.4 & 1.9 & 118 & 1 & 18 & 112 & 27 \\
\hline 23-OE-7 & 827 & 0.91 & 0.2 & 5.5 & 66 & 630 & 16 & 55 & 0.11 & 0.87 & 1 & 2.3 & 289 & 0.1 & $<0.05$ & 7 & 0.3 & 0.4 & 2 & 128 & 1 & 21 & 127 & 19 \\
\hline 23-OE-8 & 720 & 0.83 & 0.3 & 5.7 & 58 & 590 & 15 & 53 & 0.15 & 0.72 & 1 & 1.6 & 202 & 0.2 & $<0.05$ & 6 & 0.3 & 0.3 & 1.8 & 116 & 0.8 & 18 & 113 & 34 \\
\hline 23-OE-9 & 808 & 1.25 & 0.1 & 7 & 62 & 750 & 16 & 72 & 0.17 & 1.11 & 2 & 2.1 & 263 & 0.4 & $<0.05$ & 6 & 0.4 & 0.5 & 2.2 & 134 & 1 & 16 & 110 & 45 \\
\hline 23-OE-10 & 702 & 0.18 & 0.7 & 3.2 & 104 & 390 & 10 & 11 & 0.04 & 0.21 & 2 & 1.6 & 1450 & 0.2 & $<0.05$ & 4 & 0.2 & 0.1 & 2.7 & 80 & 0.3 & 10 & 50 & 48 \\
\hline \multicolumn{25}{|c|}{ Upper Tailings above Adit at the Oat Hill Extension Mine } \\
\hline 23-OE-12 & 545 & 0.65 & 0.5 & 6.6 & 48 & 600 & 13 & 56 & 0.08 & 0.71 & 2 & 1.6 & 207 & 0.3 & $<0.05$ & 7 & 0.3 & 0.4 & 1.6 & 114 & 1 & 14 & 87 & 40 \\
\hline \multicolumn{25}{|c|}{ Sediments in Drainage $A$ that transects the Oat Hill Extension Tailngs Pile } \\
\hline 23-OE-13S & 575 & 1.07 & 0.6 & 7 & 68 & 850 & 27 & 82 & 0.08 & 1.15 & 1 & 6.5 & 168.5 & 0.2 & 0.08 & 8 & 0.4 & 0.5 & 1.7 & 144 & 1.4 & 14 & 120 & 37 \\
\hline 23-OE-3S & 690 & 0.89 & 0.6 & 6.6 & 68 & 840 & 23 & 73 & 0.11 & 1.1 & 2 & 2.1 & 170.5 & 0.2 & $<0.05$ & 8 & 0.4 & 0.5 & 1.8 & 140 & 1.2 & 15 & 121 & 28 \\
\hline \multicolumn{25}{|c|}{ Sample of retort brick at Oat Hill Extension Mine } \\
\hline 23-OE-11 & 946 & 0.73 & 1.0 & 7.7 & 82 & 830 & 14 & 86 & 0.01 & 0.77 & 1 & 2.1 & 113.5 & 0.3 & $<0.05$ & 7 & 0.5 & 0.4 & 1.7 & 144 & 0.8 & 16 & 110 & 43 \\
\hline \multicolumn{25}{|c|}{ Background soil sample at Oat Hill Extension Office Site } \\
\hline 23-OE-14 & 698 & 0.88 & 0.1 & 6.6 & 54 & 940 & 15 & 70 & 0.02 & 0.96 & $<1$ & 1.8 & 81 & 0.1 & $<0.05$ & 7 & 0.4 & 0.4 & 1.8 & 130 & 1.1 & 15 & 123 & 18 \\
\hline
\end{tabular}

\begin{tabular}{|c|c|c|c|c|c|c|}
\hline \multicolumn{3}{|c|}{ Screening criteria, in mg/kg (ppm) } & \multirow[b]{2}{*}{1000} & & \multirow{2}{*}{\multicolumn{2}{|c|}{700}} \\
\hline BLM Campe & 19000 & 2700 & & 50 & & \\
\hline \multicolumn{2}{|c|}{ BLM Eco Risk } & & 6 & & & \\
\hline EPA PRG & 1800 & 1600 & & 31 & 390 & \\
\hline 23-OE-1 & - & - & + & $-\quad-$ & - & - \\
\hline 23-OE-2 & - & - & $-\quad+$ & $-\quad-$ & - & - \\
\hline 23-OE-4 & - & - & + & $-\quad-$ & - & - \\
\hline 23-OE-5 & - & - & + & $-\quad-$ & - & - \\
\hline 23-OE-6 & - & - & + & $-\quad-$ & - & - \\
\hline 23-OE-7 & - & - & + & $-\quad-$ & - & - \\
\hline 23-OE-8 & - & - & + & $-\quad-$ & - & - \\
\hline 23-OE-9 & - & - & + & $-\quad-$ & - & - \\
\hline 23-OE-10 & - & - & + & $-\quad-$ & - & \\
\hline 23-OE-12 & - & - & + & $-\quad-$ & - & \\
\hline 23-OE-3S & - & - & + & $-\quad-$ & - & \\
\hline 23-OE-13S & - & - & + & $-\quad-$ & - & - \\
\hline 23-OE-11 & - & - & + & - - & - & 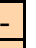 \\
\hline 23-OE-14 & - & - & $-\quad+$ & $-\quad-$ & + & + \\
\hline
\end{tabular}
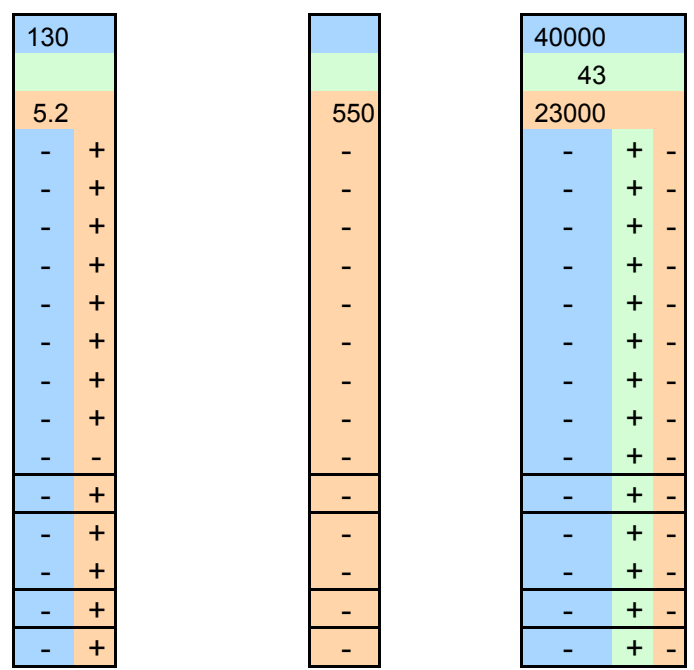


\section{Appendix 1. Thermodynamic Modeling Results}

\section{A1.1 Sample 04JC1}

\begin{tabular}{|c|c|c|}
\hline Temperature $=$ & C & Pressure $=$ \\
\hline 8.400 & & $\log \mathrm{fO} 2=$ \\
\hline 0.7423 volts & & 13.0145 \\
\hline Ionic strength & $=$ & 0.006416 \\
\hline Activity of water & $=$ & 0.999995 \\
\hline Solvent mass & $=$ & $0.999999 \mathrm{~kg}$ \\
\hline Solution mass & $=$ & $1.000274 \mathrm{~kg}$ \\
\hline Solution density & $=$ & 1.020 \\
\hline Chlorinity & $=$ & 0.000141 molal \\
\hline Dissolved solids & $=$ & $274 \mathrm{mg} / \mathrm{kg}$ sol'n \\
\hline Rock mass & $=$ & $0.000000 \mathrm{~kg}$ \\
\hline arbonate alkalini & & $57.09 \mathrm{mg} / \mathrm{kg}$ as \\
\hline
\end{tabular}

No minerals in system.

\begin{tabular}{|c|c|c|c|c|}
\hline Aqueous species & molality & $\mathrm{mg} / \mathrm{kg}$ sol'n & act. coef. & $\log$ act \\
\hline & & & & \\
\hline $\mathrm{Mg}++$ & 0.001650 & 40.10 & 0.7376 & -2.9146 \\
\hline $\mathrm{HCO} 3-$ & 0.001088 & 66.39 & 0.9213 & -2.9989 \\
\hline SO4-- & 0.0008443 & 81.08 & 0.7166 & -3.2182 \\
\hline SiO2 ( aq) & 0.0004752 & 28.54 & 1.0017 & -3.3224 \\
\hline $\mathrm{O} 2$ ( aq ) & 0.0003151 & 10.08 & 1.0017 & -3.5008 \\
\hline $\mathrm{Ca}++$ & 0.0003105 & 12.44 & 0.7275 & -3.6462 \\
\hline $\mathrm{Na}+$ & 0.0002381 & 5.473 & 0.9204 & -3.6592 \\
\hline $\mathrm{Cl}-$ & 0.0001405 & 4.981 & 0.9185 & -3.8891 \\
\hline MgSO4 & 0.0001169 & 14.06 & 1.0000 & -3.9323 \\
\hline $\mathrm{K}+$ & $4.585 e-005$ & 1.792 & 0.9185 & -4.3756 \\
\hline Caso4 & $2.693 e-005$ & 3.665 & 1.0000 & -4.5698 \\
\hline H3SiO4- & $1.434 e-005$ & 1.363 & 0.9204 & -4.8796 \\
\hline $\mathrm{MgHCO} 3+$ & $1.308 e-005$ & 1.115 & 0.9204 & -4.9196 \\
\hline CO3-- & $1.245 e-005$ & 0.7467 & 0.7194 & -5.0480 \\
\hline $\mathrm{CO} 2$ ( aq) & $1.101 e-005$ & 0.4844 & 1.0000 & -4.9582 \\
\hline $\mathrm{F}-$ & $9.865 e-006$ & 0.1874 & 0.9195 & -5.0424 \\
\hline $\mathrm{MgCO} 3$ & $7.121 e-006$ & 0.6002 & 1.0000 & -5.1475 \\
\hline СаHCO3+ & $3.764 e-006$ & 0.3804 & 0.9225 & -5.4594 \\
\hline $\mathrm{CaCO} 3$ & $2.831 e-006$ & 0.2833 & 1.0000 & -5.5481 \\
\hline $\mathrm{Fe}(\mathrm{OH}) 3$ & $1.383 e-006$ & 0.1478 & 1.0000 & -5.8591 \\
\hline $\mathrm{OH}-$ & $1.170 e-006$ & 0.01990 & 0.9195 & -5.9681 \\
\hline MgH3SiO4+ & $8.082 e-007$ & 0.09648 & 0.9204 & -6.1285 \\
\hline $\mathrm{Mn}++$ & $7.964 e-007$ & 0.04374 & 0.7275 & -6.2370 \\
\hline NaSO4- & $6.720 e-007$ & 0.07998 & 0.9204 & -6.2087 \\
\hline $\mathrm{MgF}+$ & $6.390 e-007$ & 0.02766 & 0.9204 & -6.2305 \\
\hline $\mathrm{Al}(\mathrm{OH}) 4-$ & $5.505 e-007$ & 0.05229 & 0.9204 & -6.2953 \\
\hline MgH2SiO4 & $3.851 e-007$ & 0.04559 & 1.0000 & -6.4144 \\
\hline $\mathrm{NaHCO} 3$ & $3.669 e-007$ & 0.03081 & 1.0000 & -6.4355 \\
\hline $\mathrm{MnO} 4-$ & $3.135 e-007$ & 0.03728 & 0.9204 & -6.5398 \\
\hline $\mathrm{MgCl}+$ & $2.855 e-007$ & 0.01706 & 0.9204 & -6.5804 \\
\hline $\mathrm{CaCl}+$ & $2.006 e-007$ & 0.01515 & 0.9204 & -6.7337 \\
\hline $\mathrm{MgOH}+$ & $1.986 e-007$ & 0.008202 & 0.9204 & -6.7381 \\
\hline KSO4- & $1.906 e-007$ & 0.02576 & 0.9204 & -6.7558 \\
\hline СaH3SiO4+ & $8.519 e-008$ & 0.01151 & 0.9204 & -7.1056 \\
\hline $\mathrm{Fe}(\mathrm{OH}) 4-$ & $6.119 e-008$ & 0.007578 & 0.9204 & -7.2494 \\
\hline $\mathrm{MnSO} 4$ & $5.603 e-008$ & 0.008458 & 1.0000 & -7.2516 \\
\hline $\mathrm{Mg} 2 \mathrm{CO} 3++$ & $5.155 e-008$ & 0.005597 & 0.7222 & -7.4292 \\
\hline $\mathrm{Mg}(\mathrm{H} 3 \mathrm{SiO} 4) 2$ & $5.042 e-008$ & 0.01081 & 1.0000 & -7.2974 \\
\hline NaH3SiO4 & $4.210 e-008$ & 0.004971 & 1.0000 & -7.3757 \\
\hline $\mathrm{Fe}(\mathrm{OH}) 2+$ & $2.387 e-008$ & 0.002145 & 0.9204 & -7.6581 \\
\hline $\mathrm{CaF}+$ & $2.315 e-008$ & 0.001367 & 0.9204 & -7.6715 \\
\hline $\mathrm{MnCO} 3$ & $2.181 e-008$ & 0.002506 & 1.0000 & -7.6614 \\
\hline $\mathrm{MnHCO} 3+$ & $1.125 e-008$ & 0.001304 & 0.9204 & -7.9850 \\
\hline $\mathrm{NaCO} 3-$ & $8.982 e-009$ & 0.0007453 & 0.9204 & -8.0826 \\
\hline СаH2SiO4 & $6.029 e-009$ & 0.0008088 & 1.0000 & -8.2197 \\
\hline $\mathrm{Al}(\mathrm{OH}) 3$ & $5.409 e-009$ & 0.0004218 & 1.0000 & -8.2669 \\
\hline $\mathrm{CaOH}+$ & $4.816 e-009$ & 0.0002749 & 0.9204 & -8.3534 \\
\hline $\mathrm{H}+$ & $4.287 e-009$ & $4.320 e-006$ & 0.9285 & -8.4000 \\
\hline $\mathrm{MnOH}+$ & $1.768 e-009$ & 0.0001272 & 0.9204 & -8.7885 \\
\hline $\mathrm{Ca}(\mathrm{H} 3 \mathrm{SiO} 4) 2$ & $1.106 e-009$ & 0.0002547 & 1.0000 & -8.9561 \\
\hline $\mathrm{NaCl}$ & $5.582 e-010$ & $3.261 e-005$ & 1.0000 & -9.2532 \\
\hline $\mathrm{MnO} 4--$ & $3.760 e-010$ & $4.471 e-005$ & 0.7166 & -9.5695 \\
\hline
\end{tabular}




$\begin{array}{llllr}\mathrm{NaF} & 2.207 \mathrm{e}-010 & 9.264 \mathrm{e}-006 & 1.0000 & -9.6562 \\ \mathrm{HSO}- & 1.892 \mathrm{e}-010 & 1.836 \mathrm{e}-005 & 0.9204 & -9.7591 \\ \mathrm{H} 2 \mathrm{SiO4--} & 1.746 \mathrm{e}-010 & 1.642 \mathrm{e}-005 & 0.7166 & -9.9027 \\ \mathrm{H} 6(\mathrm{H} 2 \mathrm{SiO4}) 4-- & 1.664 \mathrm{e}-010 & 6.362 \mathrm{e}-005 & 0.7166 & -9.9236 \\ \mathrm{NaOH} & 1.476 \mathrm{e}-010 & 5.904 \mathrm{e}-006 & 1.0000 & -9.8308 \\ \mathrm{KCl} & 1.198 \mathrm{e}-010 & 8.926 \mathrm{e}-006 & 1.0000 & -9.9217 \\ \mathrm{MnF}+ & 1.039 \mathrm{e}-010 & 7.678 \mathrm{e}-006 & 0.9204 & -10.0195 \\ \mathrm{MnCl}+ & 5.152 \mathrm{e}-011 & 4.656 \mathrm{e}-006 & 0.9204 & -10.3240 \\ \mathrm{Al}(\mathrm{OH}) 2+ & 4.624 \mathrm{e}-011 & 2.820 \mathrm{e}-006 & 0.9204 & -10.3710 \\ \mathrm{HF} & 4.405 \mathrm{e}-011 & 8.810 \mathrm{e}-007 & 1.0000 & -10.3561 \\ \mathrm{KOH} & 1.363 \mathrm{e}-011 & 7.644 \mathrm{e}-007 & 1.0000 & -10.8656 \\ \mathrm{Mg} 2 \mathrm{OH}+++ & 1.254 \mathrm{e}-011 & 8.228 \mathrm{e}-007 & 0.5039 & -11.1992 \\ \mathrm{Mn} 2(\mathrm{OH}) 3+ & 7.357 \mathrm{e}-012 & 1.183 e-006 & 0.9204 & -11.1694 \\ \mathrm{Mn}(\mathrm{OH}) 2 & 2.327 \mathrm{e}-012 & 2.069 \mathrm{e}-007 & 1.0000 & -11.6332\end{array}$

Mineral saturation states

$\log \mathrm{Q} / \mathrm{K} \quad \log \mathrm{Q} / \mathrm{K}$

\begin{tabular}{|c|c|c|c|}
\hline Birnessite & $62.0314 \mathrm{~s} / \mathrm{sat}$ & Corundum & -5.6814 \\
\hline Todorokite & $53.8835 \mathrm{~s} / \mathrm{sat}$ & Analc-dehydr & -5.9301 \\
\hline Antigorite & $23.5060 \mathrm{~s} / \mathrm{sat}$ & Tephroite & -6.3095 \\
\hline Nontronit-Mg & $17.9904 \mathrm{~s} / \mathrm{sat}$ & Kieserite & -6.3415 \\
\hline Nontronit-Ca & $17.8719 \mathrm{~s} / \mathrm{sat}$ & Kalicinite & -7.3269 \\
\hline Nontronit-K & $17.3791 \mathrm{~s} / \mathrm{sat}$ & Monticellite & -7.3284 \\
\hline Nontronit-Na & $17.2487 \mathrm{~s} / \mathrm{sat}$ & $\mathrm{Ca} 2 \mathrm{Si} 3 \mathrm{O}^{\wedge} 5 / 2 \mathrm{H} 2 \mathrm{O}$ & -7.5949 \\
\hline Hematite & $12.8693 \mathrm{~s} / \mathrm{sat}$ & Jarosite-K & -7.7439 \\
\hline Bixbyite & $11.7912 \mathrm{~s} / \mathrm{sat}$ & Grossular & -7.9896 \\
\hline Hausmannite & $10.7270 \mathrm{~s} / \mathrm{sat}$ & Manganosite & -8.1233 \\
\hline Pyrolusite & $10.2973 \mathrm{~s} / \mathrm{sat}$ & Mirabilite & -8.9470 \\
\hline Andradite & $8.4136 \mathrm{~s} / \mathrm{sat}$ & Sylvite & -9.1036 \\
\hline Clinoptil-K & $7.5931 \mathrm{~s} / \mathrm{sat}$ & Halite & -9.1091 \\
\hline Clinoptil-Ca & $6.5058 \mathrm{~s} / \mathrm{sat}$ & MHSH (Mg1.5) & -9.1485 \\
\hline Saponite-Mg & $6.4073 \mathrm{~s} / \mathrm{sat}$ & Cordier^hydr & -9.2637 \\
\hline Saponite-Ca & $6.2875 \mathrm{~s} / \mathrm{sat}$ & $\mathrm{NaFeO} 2$ ( C) & -9.3334 \\
\hline Goethite & $5.9729 \mathrm{~s} / \mathrm{sat}$ & Hydromagnesite & -9.6083 \\
\hline Saponite-K & $5.7911 \mathrm{~s} / \mathrm{sat}$ & Spinel & -9.6289 \\
\hline Talc & $5.7784 \mathrm{~s} / \mathrm{sat}$ & Jarosite-Na & -9.6830 \\
\hline Manganite & $5.7492 \mathrm{~s} / \mathrm{sat}$ & Cronstedt-7A & -10.0436 \\
\hline Saponite-Na & $5.6643 \mathrm{~s} / \mathrm{sat}$ & Arcanite & -10.1025 \\
\hline Smectite-Reykjan & $5.2879 \mathrm{~s} / \mathrm{sat}$ & Portlandite & -10.2674 \\
\hline Saponite-H & $5.1288 \mathrm{~s} / \mathrm{sat}$ & $\mathrm{Ca}(\mathrm{OH}) 2(\mathrm{C})$ & -10.2674 \\
\hline Epidote-ord & $4.9176 \mathrm{~s} / \mathrm{sat}$ & Thenardite & -10.2982 \\
\hline Epidote & $4.9169 \mathrm{~s} / \mathrm{sat}$ & Gaylussite & -10.6330 \\
\hline Phengite & $4.8676 \mathrm{~s} / \mathrm{sat}$ & $\mathrm{Mg} 2 \mathrm{Cl}(\mathrm{OH}) 3^{\wedge} 4 \mathrm{H} 2 \mathrm{O}$ & -11.0770 \\
\hline Tremolite & $4.7374 \mathrm{~s} / \mathrm{sat}$ & Pirssonite & -11.2014 \\
\hline Ferrite-Mg & $4.6942 \mathrm{~s} / \mathrm{sat}$ & Ca-Al Pyroxene & -11.5126 \\
\hline Clinochl-14A & $4.3247 \mathrm{~s} / \mathrm{sat}$ & $\operatorname{MgSO} 4(\mathrm{c})$ & -11.7262 \\
\hline Phlogopite & $4.1606 \mathrm{~s} / \mathrm{sat}$ & Cordier^anhy & -11.8580 \\
\hline Muscovite & $4.0978 \mathrm{~s} / \mathrm{sat}$ & Alunite & -11.9142 \\
\hline Heulandite & $3.8585 \mathrm{~s} / \mathrm{sat}$ & $\mathrm{KNaCO} 3^{\wedge} 6 \mathrm{H} 2 \mathrm{O}$ & -12.0369 \\
\hline Mordenite-K & $3.7969 \mathrm{~s} / \mathrm{sat}$ & Ferrosilite & -12.4965 \\
\hline Ferrite-Ca & $3.6283 \mathrm{~s} / \mathrm{sat}$ & $\mathrm{MnSO} 4$ ( c) & -12.5243 \\
\hline Sepiolite & $3.4883 \mathrm{~s} / \mathrm{sat}$ & Siderite & -12.7491 \\
\hline Illite & $3.3986 \mathrm{~s} / \mathrm{sat}$ & $\mathrm{FeO}(\mathrm{c})$ & -13.3426 \\
\hline Beidellit-Mg & $3.0448 \mathrm{~s} / \mathrm{sat}$ & Wustite & -13.4707 \\
\hline Beidellit-Ca & $2.9264 \mathrm{~s} / \mathrm{sat}$ & Akermanite & -13.5386 \\
\hline Clinoptil-Mg & $2.6546 \mathrm{~s} / \mathrm{sat}$ & FeF3 (c) & -14.1988 \\
\hline Maximum Microcli & $2.5272 \mathrm{~s} / \mathrm{sat}$ & Mercallite & -14.3171 \\
\hline K-feldspar & $2.5256 \mathrm{~s} / \mathrm{sat}$ & Kainite & -14.3472 \\
\hline Beidellit-K & $2.4300 \mathrm{~s} / \mathrm{sat}$ & Bloedite & -14.4061 \\
\hline Pyrophyllite & $2.4238 \mathrm{~s} / \mathrm{sat}$ & $\mathrm{Fe}(\mathrm{OH}) 2(\mathrm{ppd})$ & -14.8048 \\
\hline Kaolinite & $2.3948 \mathrm{~s} / \mathrm{sat}$ & Hedenbergite & -15.1280 \\
\hline Beidellit-Na & $2.3031 \mathrm{~s} / \mathrm{sat}$ & $\mathrm{MgOHCl}$ & -15.2249 \\
\hline Chrysotile & $2.0032 \mathrm{~s} / \mathrm{sat}$ & $\mathrm{Ca} 2 \mathrm{SiO} 4^{\wedge} 7 / 6 \mathrm{H} 2 \mathrm{O}$ & -15.2640 \\
\hline Laumontite & $1.9559 \mathrm{~s} / \mathrm{sat}$ & Bischofite & $-15 \cdot 3237$ \\
\hline Beidellit-H & $1.7649 \mathrm{~s} / \mathrm{sat}$ & Antarcticite & -15.4917 \\
\hline Clinoptil-Na & $1.6297 \mathrm{~s} / \mathrm{sat}$ & Hercynite & -15.5839 \\
\hline $\mathrm{Fe}(\mathrm{OH}) 3(\mathrm{ppd})$ & $1.4635 \mathrm{~s} / \mathrm{sat}$ & $\mathrm{Na2Si2O5}$ & -15.6939 \\
\hline Amesite-14A & $1.3535 \mathrm{~s} / \mathrm{sat}$ & Ca2SiO4 (gamma) & -15.9706 \\
\hline Dolomite & $1.3528 \mathrm{~s} / \mathrm{sat}$ & Pargasite & -16.1825 \\
\hline Dolomite-ord & $1.3528 \mathrm{~s} / \mathrm{sat}$ & $\mathrm{CaCl}^{\wedge} 2^{\wedge} \mathrm{H} 2 \mathrm{O}$ & -16.3744 \\
\hline Sanidine high & $1.2550 \mathrm{~s} / \mathrm{sat}$ & $\mathrm{K} 2 \mathrm{CO}^{\wedge} 3 / 2 \mathrm{H} 2 \mathrm{O}$ & -16.5364 \\
\hline Smectite-low-Fe- & $0.9025 \mathrm{~s} / \mathrm{sat}$ & $\mathrm{Na} 2 \mathrm{SiO} 3$ & -16.6765 \\
\hline Quartz & $0.8814 \mathrm{~s} / \mathrm{sat}$ & $\mathrm{MnCl} 2^{\wedge} 4 \mathrm{H} 2 \mathrm{O}$ & -16.7940 \\
\hline Clinochl-7A & $0.8620 \mathrm{~s} / \mathrm{sat}$ & Larnite & -17.5003 \\
\hline Mordenite-Na & $0.8122 \mathrm{~s} / \mathrm{sat}$ & $\mathrm{MnCl} 2^{\wedge} 2 \mathrm{H} 2 \mathrm{O}$ & -18.2097 \\
\hline
\end{tabular}




\begin{tabular}{|c|c|c|c|}
\hline Tridymite & $0.7053 \mathrm{~s} / \mathrm{sat}$ & $\mathrm{MgCl}^{\wedge} 4 \mathrm{H} 2 \mathrm{O}$ & -18.4317 \\
\hline Paragonite & $0.6909 \mathrm{~s} / \mathrm{sat}$ & Melanterite & -18.9253 \\
\hline Magnetite & $0.6812 \mathrm{~s} / \mathrm{sat}$ & Ripidolit-14A & -19.2978 \\
\hline Chalcedony & $0.6000 \mathrm{~s} / \mathrm{sat}$ & Gehlenite & -19.3793 \\
\hline Cristobalite & $0.3060 \mathrm{~s} / \mathrm{sat}$ & $\mathrm{CaCl} 2^{\wedge} 2 \mathrm{H} 2 \mathrm{O}$ & -19.8055 \\
\hline Gibbsite & $0.1088 \mathrm{~s} / \mathrm{sat}$ & Ferrite-2-Ca & -19.8335 \\
\hline Albite low & $0.0447 \mathrm{~s} / \mathrm{sat}$ & $\mathrm{Ca}_{5 \mathrm{Si}} 6 \mathrm{O} 17^{\wedge} 21 / 2 \mathrm{H} 2$ & -19.8387 \\
\hline Albite & $0.0446 \mathrm{~s} / \mathrm{sat}$ & $\mathrm{MnCl} 2^{\wedge} \mathrm{H} 2 \mathrm{O}$ & -19.8629 \\
\hline Calcite & -0.1090 & $\mathrm{CaCl} 2^{\wedge} \mathrm{H} 2 \mathrm{O}$ & -19.9904 \\
\hline Magnesite & -0.2345 & Lime & -20.8108 \\
\hline Dolomite-dis & -0.2722 & Rankinite & -21.1398 \\
\hline Aragonite & -0.2751 & $\mathrm{Ca}_{5 \mathrm{Si}} 6 \mathrm{O} 17^{\wedge} 11 / 2 \mathrm{H} 2$ & -22.0555 \\
\hline Lawsonite & -0.3166 & Ripidolit-7A & -22.7633 \\
\hline Anthophyllite & -0.4425 & Scacchite & -23.2493 \\
\hline Amrph^silica & -0.4939 & Carnallite & -23.3558 \\
\hline Rhodochrosite & -0.7202 & Hydrophilite & -23.7580 \\
\hline Diaspore & -0.7786 & $\mathrm{MgCl}^{\wedge} 2^{\wedge} 2 \mathrm{H} 2 \mathrm{O}$ & -24.1788 \\
\hline Analcime & -1.0252 & Merwinite & -24.3629 \\
\hline Monohydrocalcite & -1.0822 & Chamosite-7A & -24.3692 \\
\hline $\mathrm{Mn}(\mathrm{OH}) 3(\mathrm{C})$ & -1.1293 & FeSO4 (c) & -24.4838 \\
\hline Albite high & -1.3464 & $\mathrm{Ca} 4 \mathrm{Si} 3010^{\wedge} 3 / 2 \mathrm{H} 2 \mathrm{O}$ & -24.5444 \\
\hline Enstatite & -1.4613 & $\mathrm{Na} 3 \mathrm{H}(\mathrm{SO} 4) 2$ & -24.5479 \\
\hline Diopside & -1.4682 & $\mathrm{Ca} 2 \mathrm{Cl} 2(\mathrm{OH}) 2^{\wedge} \mathrm{H} 2 \mathrm{O}$ & -25.1677 \\
\hline Prehnite & -1.5086 & $\mathrm{Ca} 5 \mathrm{Si} 6 \mathrm{O} 17^{\wedge} 3 \mathrm{H} 2 \mathrm{O}$ & -26.0551 \\
\hline Boehmite & -1.6806 & Fayalite & -26.1180 \\
\hline Smectite-high-Fe & -1.7432 & FeF2 (c) & -26.1333 \\
\hline Gypsum & -2.4084 & $\mathrm{MgCl} 2^{\wedge} \mathrm{H} 2 \mathrm{O}$ & -27.7091 \\
\hline Jadeite & -2.4594 & $\mathrm{Ca} 3 \mathrm{Si} 2 \mathrm{O}^{\wedge}$ З $\mathrm{H} 2 \mathrm{O}$ & -29.5057 \\
\hline Kalsilite & -2.5336 & Minnesotaite & -32.0173 \\
\hline Huntite & -2.6292 & Burkeite & -32.0252 \\
\hline Fluorite & -2.6313 & Annite & -32.7742 \\
\hline Anhydrite & -2.6922 & $\mathrm{KMgCl}^{\wedge} 2 \mathrm{H} 2 \mathrm{O}$ & -33.5842 \\
\hline Wairakite & -2.8027 & Chloromagnesite & -33.7243 \\
\hline Rhodonite & -2.9202 & Greenalite & -34.4342 \\
\hline Dawsonite & -3.0874 & Lawrencite & -35.5295 \\
\hline Brucite & -3.2864 & $\mathrm{Ca} 6 \mathrm{Si} 6018^{\wedge} \mathrm{H} 2 \mathrm{O}$ & -36.8727 \\
\hline Nesquehonite & -3.2982 & $\mathrm{Ca} 4 \mathrm{Cl} 2(\mathrm{OH}) 6^{\wedge} 13 \mathrm{H} 2$ & -40.5750 \\
\hline Bassanite & -3.3239 & Ca3sio5 & -40.7384 \\
\hline $\mathrm{CaSO}^{\wedge} 1 / 2 \mathrm{H} 2 \mathrm{O}$ ( bet & -3.5060 & $\mathrm{KMgCl} 3$ & -41.2551 \\
\hline 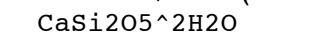 & -3.5910 & Molysite & -44.4385 \\
\hline Kyanite & -3.6532 & $\mathrm{Al} 2(\mathrm{SO} 4) 3^{\wedge} 6 \mathrm{H} 2 \mathrm{O}$ & -46.1328 \\
\hline Andalusite & -3.9563 & Fe2 (SO4) $3(\mathrm{C})$ & -48.6428 \\
\hline Margarite & -4.1204 & Tachyhydrite & -50.7852 \\
\hline Epsomite & -4.2556 & $\mathrm{Na} 4 \mathrm{SiO} 4$ & -52.9174 \\
\hline Wollastonite & -4.2974 & Daphnite-14A & -55.4939 \\
\hline Sillimanite & -4.3366 & Daphnite-7A & -58.9655 \\
\hline Clinozoisite & -4.3576 & $\mathrm{~K} 8 \mathrm{H} 4(\mathrm{CO} 3) 6^{\wedge} 3 \mathrm{H} 2 \mathrm{O}$ & -62.1921 \\
\hline Zoisite & -4.4048 & Al2 (SO4) 3 & -64.6102 \\
\hline Artinite & -4.4182 & Graphite & -78.4476 \\
\hline Hexahydrite & -4.5715 & $\mathrm{Na} 6 \mathrm{Si} 207$ & -83.0656 \\
\hline Pseudowollastoni & -4.7137 & Misenite & -95.0075 \\
\hline Nepheline & -4.8690 & Sulfur-Rhmb & -111.9342 \\
\hline Pentahydrite & -4.8978 & Alabandite & -146.2425 \\
\hline $\operatorname{MgF} 2(\mathrm{C})$ & -4.9218 & Pyrrhotite & -148.3603 \\
\hline Forsterite & -5.0606 & Troilite & -154.6743 \\
\hline Anorthite & -5.0644 & Pyrite & -255.7272 \\
\hline $\mathrm{Mn}(\mathrm{OH}) 2(\mathrm{am})$ & -5.3707 & O-phth acid(c) & -618.8118 \\
\hline Leonhardtite & -5.4270 & & \\
\hline ases & fugacity & $\log$ fug. & \\
\hline------- & -ー-ーー-ーー-ー- & --------- & \\
\hline $\mathrm{O} 2(\mathrm{~g})$ & 0.2000 & -0.699 & \\
\hline Steam & 0.01600 & -1.796 & \\
\hline $\mathrm{CO} 2(\mathrm{~g})$ & 0.0002275 & -3.643 & \\
\hline $\mathrm{H} 2(\mathrm{~g})$ & $8.245 e-044$ & -43.084 & \\
\hline $\mathrm{H} 2 \mathrm{~S}(\mathrm{~g})$ & $9.329 e-150$ & -149.030 & \\
\hline $\mathrm{CH} 4(\mathrm{~g})$ & $3.843 e-152$ & -151.415 & \\
\hline $\mathrm{s} 2(\mathrm{~g})$ & $2.451 e-239$ & -238.611 & \\
\hline Original basis tot & al moles & $\mathrm{uid}_{\mathrm{S}}$ & \\
\hline------------------ & ------ー------ & -------------- & \\
\hline $\mathrm{Al}+++$ & $56 e-007$ & 0.0150 & \\
\hline $\mathrm{Ca}++$ & .000344 & 13.8 & \\
\hline $\mathrm{Cl}-$ & .000141 & 5.00 & \\
\hline
\end{tabular}




$\begin{array}{lrrr}\mathrm{F}- & 1.05 \mathrm{e}-005 & 1.05 e-005 & 0.200 \\ \mathrm{Fe}++ & 1.47 \mathrm{e}-006 & 1.47 \mathrm{e}-006 & 0.0820 \\ \mathrm{H}+ & -3.51 \mathrm{e}-005 & -3.51 \mathrm{e}-005 & -0.0354 \\ \mathrm{H} 2 \mathrm{O} & 55.5 & 55.5 & 1.00 \mathrm{e}+006 \\ \mathrm{HCO3-} & 0.00114 & 0.00114 & 69.5 \\ \mathrm{~K}+ & 4.60 \mathrm{e}-005 & 4.60 \mathrm{e}-005 & 1.80 \\ \mathrm{Mg}++ & 0.00179 & 0.00179 & 43.5 \\ \mathrm{Mn}++ & 1.20 \mathrm{e}-006 & 1.20 \mathrm{e}-006 & 0.0660 \\ \mathrm{Na}+ & 0.000239 & 0.000239 & 5.50 \\ \mathrm{O} 2(\mathrm{aq}) & 0.000316 & 0.000316 & 10.1 \\ \mathrm{SO} 4-- & 0.000989 & 0.000989 & 95.0 \\ \mathrm{SiO} \text { (aq) } & 0.000491 & 0.000491 & 29.5\end{array}$

\begin{tabular}{lrrr} 
Elemental composition & \multicolumn{2}{c}{ In fluid } \\
total moles & moles & mg/kg \\
\hline Aluminum & $5.559 e-007$ & $5.559 e-007$ & 0.01500 \\
Calcium & 0.0003443 & 0.0003443 & 13.80 \\
Carbon & 0.001139 & 0.001139 & 13.68 \\
Chlorine & 0.0001410 & 0.0001410 & 4.999 \\
Fluorine & $1.053 e-005$ & $1.053 e-005$ & 0.1999 \\
Hydrogen & 111.0 & 111.0 & $1.119 e+005$ \\
Iron & $1.468 \mathrm{e}-006$ & $1.468 \mathrm{e}-006$ & 0.08198 \\
Magnesium & 0.001790 & 0.001790 & 43.49 \\
Manganese & $1.201 \mathrm{e}-006$ & $1.201 \mathrm{e}-006$ & 0.06598 \\
Oxygen & 55.52 & 55.52 & $8.880 \mathrm{e}+005$ \\
Potassium & $4.604 \mathrm{e}-005$ & $4.604 \mathrm{e}-005$ & 1.800 \\
Silicon & 0.0004910 & 0.0004910 & 13.79 \\
Sodium & 0.0002392 & 0.0002392 & 5.498 \\
Sulfur & 0.0009890 & 0.0009890 & 31.70
\end{tabular}

\section{A1.2 Sample 04JC2}

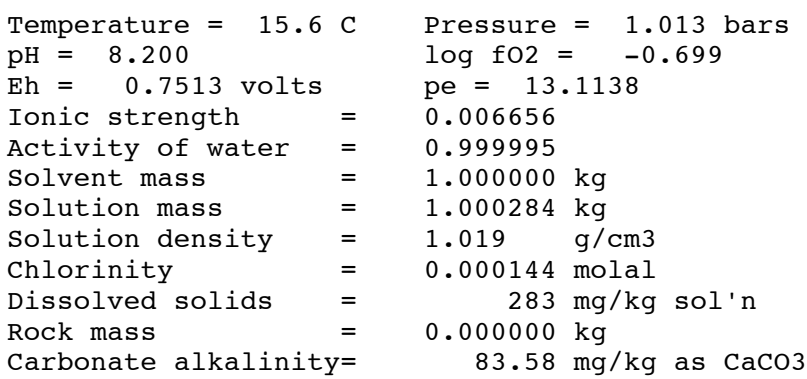

No minerals in system.

\begin{tabular}{|c|c|c|c|c|}
\hline Aqueous species & molality & $\mathrm{mg} / \mathrm{kg}$ sol'n & act. coef. & $\log$ act. \\
\hline $\mathrm{HCO} 3-$ & 0.001602 & 9771 & 0.9199 & -28316 \\
\hline $\mathrm{Mg}++$ & 0.001366 & 33.19 & 0.7338 & -2.9989 \\
\hline $\mathrm{Ca}++$ & 0.0008142 & 32.62 & 0.7234 & -3.2299 \\
\hline SO4-- & 0.0005904 & 56.70 & 0.7122 & -3.3762 \\
\hline $\mathrm{Na}+$ & 0.0003378 & 7.765 & 0.9190 & -3.5080 \\
\hline $02(\mathrm{aq})$ & 0.0003074 & 9.833 & 1.0018 & -3.5116 \\
\hline SiO2 (aq) & 0.0002819 & 16.93 & 1.0018 & -3.5492 \\
\hline $\mathrm{Cl}-$ & 0.0001431 & 5.072 & 0.9171 & -3.8820 \\
\hline MgSO4 & $6.745 e-005$ & 8.116 & 1.0000 & -4.1710 \\
\hline CaSo 4 & $4.922 e-005$ & 6.699 & 1.0000 & -4.3078 \\
\hline $\mathrm{K}+$ & $4.845 e-005$ & 1.894 & 0.9171 & -4.3523 \\
\hline $\mathrm{CO} 2(\mathrm{aq})$ & $2.518 e-005$ & 1.108 & 1.0000 & -4.5990 \\
\hline $\mathrm{MgHCO} 3+$ & $1.592 \mathrm{e}-005$ & 1.358 & 0.9190 & -4.8347 \\
\hline СaHCO3+ & $1.450 e-005$ & 1.466 & 0.9212 & -4.8742 \\
\hline $\mathrm{CO} 3--$ & $1.194 \mathrm{e}-005$ & 0.7164 & 0.7151 & -5.0685 \\
\hline $\mathrm{F}-$ & $9.925 e-006$ & 0.1885 & 0.9180 & -5.0404 \\
\hline $\mathrm{CaCO} 3$ & $7.173 e-006$ & 0.7178 & 1.0000 & -5.1443 \\
\hline $\mathrm{MgCO} 3$ & $5.761 e-006$ & 0.4856 & 1.0000 & -5.2395 \\
\hline H3SiO4- & $5.608 e-006$ & 0.5332 & 0.9190 & -5.2879 \\
\hline $\mathrm{OH}-$ & $8.247 e-007$ & 0.01402 & 0.9180 & -6.1209 \\
\hline $\mathrm{NaHCO} 3$ & $7.444 e-007$ & 0.06252 & 1.0000 & -6.1282 \\
\hline NaSO4- & $6.668 e-007$ & 0.07936 & 0.9190 & -6.2127 \\
\hline $\mathrm{Al}(\mathrm{OH}) 4-$ & $6.211 e-007$ & 0.05899 & 0.9190 & -6.2435 \\
\hline $\mathrm{MgF}+$ & $5.401 e-007$ & 0.02338 & 0.9190 & -6.3042 \\
\hline
\end{tabular}




\begin{tabular}{|c|c|c|c|c|}
\hline $\mathrm{CaCl}+$ & $5.170 e-007$ & 0.03904 & 0.9190 & -6.3232 \\
\hline MgH3SiO4+ & $2.495 e-007$ & 0.02978 & 0.9190 & -6.6396 \\
\hline $\mathrm{MgCl}+$ & $2.341 e-007$ & 0.01399 & 0.9190 & -6.6673 \\
\hline KSO4- & $1.404 e-007$ & 0.01898 & 0.9190 & -6.8892 \\
\hline $\mathrm{MgOH}+$ & $1.169 e-007$ & 0.004829 & 0.9190 & -6.9688 \\
\hline СaH3SiO4+ & $8.328 e-008$ & 0.01125 & 0.9190 & -7.1162 \\
\hline MgH2SiO4 & $7.490 e-008$ & 0.008866 & 1.0000 & -7.1255 \\
\hline $\mathrm{CaF}+$ & $6.217 e-008$ & 0.003672 & 0.9190 & -7.2431 \\
\hline $\mathrm{Mg} 2 \mathrm{CO} 3++$ & $3.370 e-008$ & 0.003659 & 0.7179 & -7.6163 \\
\hline NaH3SiO4 & $2.322 e-008$ & 0.002741 & 1.0000 & -7.6341 \\
\hline $\mathrm{Mn}++$ & $1.643 e-008$ & 0.0009025 & 0.7234 & -7.9249 \\
\hline $\mathrm{NaCO} 3-$ & $1.177 e-008$ & 0.0009769 & 0.9190 & -7.9658 \\
\hline $\mathrm{CaOH}+$ & $8.946 e-009$ & 0.0005106 & 0.9190 & -8.0850 \\
\hline $\mathrm{Al}(\mathrm{OH}) 3$ & $8.852 e-009$ & 0.0006903 & 1.0000 & -8.0530 \\
\hline $\mathrm{H}+$ & $6.803 e-009$ & $6.855 e-006$ & 0.9274 & -8.2000 \\
\hline $\operatorname{Mg}(\mathrm{H} 3 \mathrm{SiO} 4) 2$ & $5.817 e-009$ & 0.001248 & 1.0000 & -8.2353 \\
\hline $\mathrm{CaH} 2 \mathrm{SiO} 4$ & $3.713 e-009$ & 0.0004981 & 1.0000 & -8.4303 \\
\hline $\mathrm{MnO} 4-$ & $1.985 e-009$ & 0.0002360 & 0.9190 & -8.7389 \\
\hline $\mathrm{NaCl}$ & $8.282 e-010$ & $4.839 e-005$ & 1.0000 & -9.0819 \\
\hline $\mathrm{MnSO} 4$ & $8.180 e-010$ & 0.0001235 & 1.0000 & -9.0872 \\
\hline $\mathrm{MnCO} 3$ & $4.149 e-010$ & $4.768 e-005$ & 1.0000 & -9.3820 \\
\hline $\mathrm{Ca}(\mathrm{H} 3 \mathrm{SiO} 4) 2$ & $4.041 e-010$ & $9.305 e-005$ & 1.0000 & -9.3935 \\
\hline $\mathrm{MnHCO} 3+$ & $3.415 e-010$ & $3.958 e-005$ & 0.9190 & -9.5034 \\
\hline $\mathrm{NaF}$ & $3.210 e-010$ & $1.347 e-005$ & 1.0000 & -9.4935 \\
\hline HSO 4- & $2.159 e-010$ & $2.095 e-005$ & 0.9190 & -9.7025 \\
\hline $\mathrm{NaOH}$ & $1.474 \mathrm{e}-010$ & $5.894 e-006$ & 1.0000 & -9.8315 \\
\hline $\mathrm{KCl}$ & $1.311 \mathrm{e}-010$ & $9.767 e-006$ & 1.0000 & -9.8826 \\
\hline $\mathrm{Al}(\mathrm{OH}) 2+$ & $1.077 e-010$ & $6.570 e-006$ & 0.9190 & -10.0043 \\
\hline $\mathrm{HF}$ & $7.174 \mathrm{e}-011$ & $1.435 e-006$ & 1.0000 & -10.1442 \\
\hline H2SiO4-- & $4.749 e-011$ & $4.468 e-006$ & 0.7122 & -10.4708 \\
\hline $\mathrm{MnOH}+$ & $2.544 e-011$ & $1.830 e-006$ & 0.9190 & -10.6311 \\
\hline $\mathrm{KOH}$ & $1.016 e-011$ & $5.699 e-007$ & 1.0000 & -10.9930 \\
\hline H6 (H2SiO4) 4-- & $8.252 e-012$ & $3.155 e-006$ & 0.7122 & -11.2308 \\
\hline $\mathrm{Mg} 2 \mathrm{OH}+++$ & $6.082 e-012$ & $3.990 e-007$ & 0.4981 & -11.5186 \\
\hline $\mathrm{MnF}+$ & $2.194 e-012$ & $1.621 \mathrm{e}-007$ & 0.9190 & -11.6955 \\
\hline $\mathrm{MnO} 4--$ & $1.601 e-012$ & $1.903 e-007$ & 0.7122 & -11.9430 \\
\hline $\mathrm{MnCl}+$ & $1.076 e-012$ & $9.726 e-008$ & 0.9190 & -12.0047 \\
\hline
\end{tabular}

Mineral saturation states

$\log \mathrm{Q} / \mathrm{K}$

$\log \mathrm{Q} / \mathrm{K}$

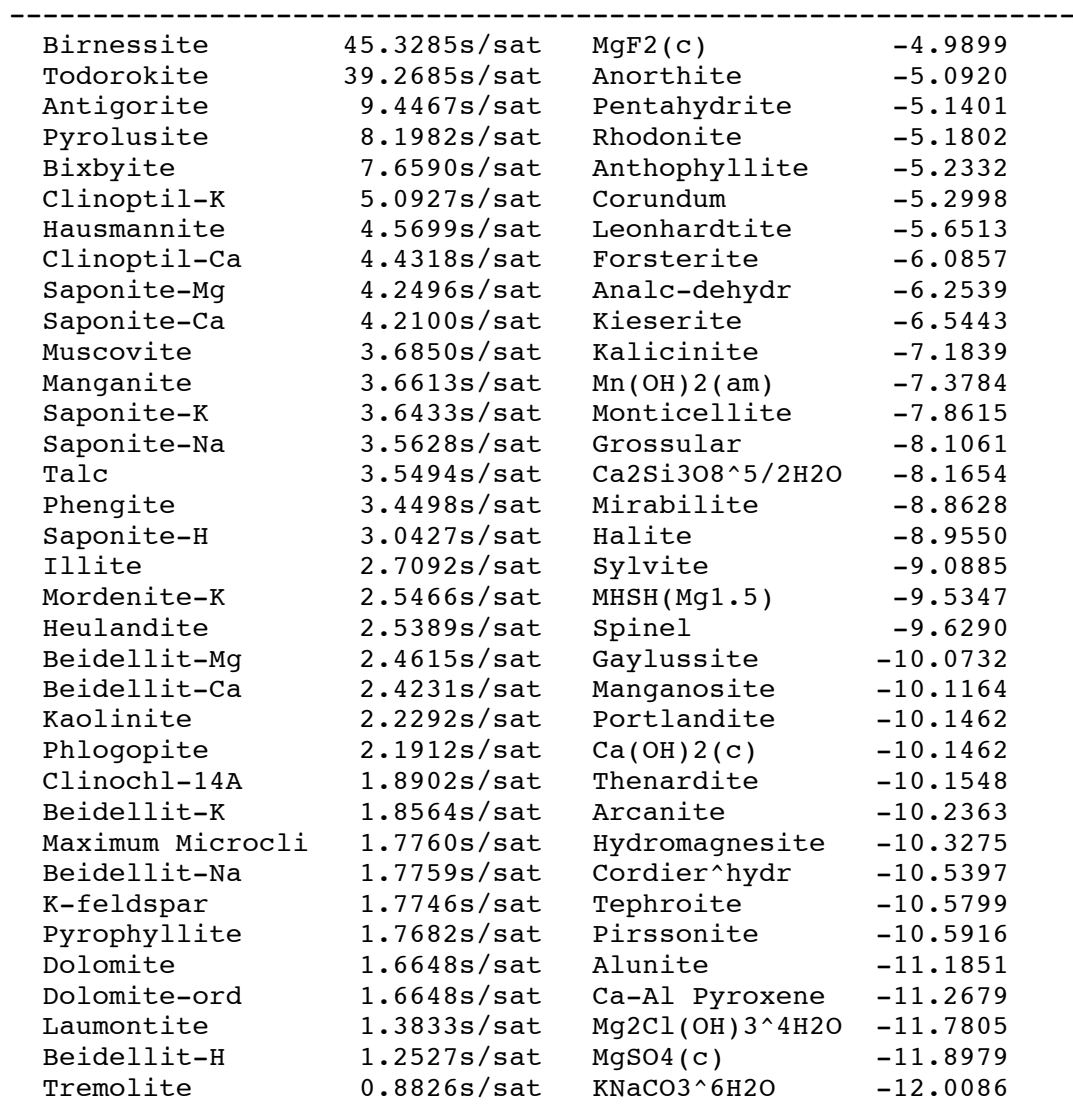




\begin{tabular}{|c|c|c|c|}
\hline Quartz & $0.6299 \mathrm{~s} / \mathrm{sat}$ & Cordier^anhy & $-13 \cdot 1200$ \\
\hline Sanidine high & $0.5129 \mathrm{~s} / \mathrm{sat}$ & Akermanite & -14.2061 \\
\hline Tridymite & $0.4551 \mathrm{~s} / \mathrm{sat}$ & Mercallite & -14.2902 \\
\hline Paragonite & $0.4324 \mathrm{~s} / \mathrm{sat}$ & MnSO4 (c) & -14.3210 \\
\hline Chalcedony & $0.3498 \mathrm{~s} / \mathrm{sat}$ & Bloedite & -14.5039 \\
\hline Sepiolite & $0.3345 \mathrm{~s} / \mathrm{sat}$ & Kainite & -14.5524 \\
\hline Calcite & $0.2931 \mathrm{~s} / \mathrm{sat}$ & Antarcticite & -15.0673 \\
\hline Chrysotile & $0.2803 \mathrm{~s} / \mathrm{sat}$ & $\mathrm{Ca} 2 \mathrm{SiO} 4^{\wedge} 7 / 6 \mathrm{H} 2 \mathrm{O}$ & -15.2902 \\
\hline Gibbsite & $0.2727 \mathrm{~s} / \mathrm{sat}$ & Bischofite & -15.3815 \\
\hline Aragonite & $0.1272 \mathrm{~s} / \mathrm{sat}$ & $\mathrm{MgOHCl}$ & -15.4063 \\
\hline Clinoptil-Mg & $0.1173 \mathrm{~s} / \mathrm{sat}$ & $\mathrm{CaCl} 2^{\wedge} 4 \mathrm{H} 2 \mathrm{O}$ & -15.9372 \\
\hline Cristobalite & $0.0575 \mathrm{~s} / \mathrm{sat}$ & Ca2SiO4 (gamma) & -15.9843 \\
\hline Dolomite-dis & $0.0497 \mathrm{~s} / \mathrm{sat}$ & $\mathrm{Na} 2 \mathrm{Si} 2 \mathrm{O5}$ & -16.1978 \\
\hline Amesite-14A & -0.0621 & $\mathrm{~K} 2 \mathrm{CO}^{\wedge} 3 / 2 \mathrm{H} 2 \mathrm{O}$ & -16.5580 \\
\hline Mordenite-Na & -0.2896 & $\mathrm{Na} 2 \mathrm{SiO} 3$ & -16.9306 \\
\hline Magnesite & -0.3163 & Larnite & -17.5056 \\
\hline Lawsonite & -0.3912 & $\mathrm{MnCl} 2^{\wedge} 4 \mathrm{H} 2 \mathrm{O}$ & -18.4592 \\
\hline Albite low & -0.5556 & $\mathrm{MgCl}^{\wedge} 4 \mathrm{H} 2 \mathrm{O}$ & -18.4674 \\
\hline Albite & -0.5557 & Pargasite & -18.5273 \\
\hline Clinoptil-Na & -0.5735 & Gehlenite & -19.0147 \\
\hline Diaspore & -0.6029 & $\mathrm{CaCl} 2^{\wedge} 2 \mathrm{H} 2 \mathrm{O}$ & -19.3402 \\
\hline Monohydrocalcite & -0.6821 & $\mathrm{CaCl} 2^{\wedge} \mathrm{H} 2 \mathrm{O}$ & -19.5190 \\
\hline Amrph^silica & -0.7344 & $\mathrm{MnCl} 2^{\wedge} 2 \mathrm{H} 2 \mathrm{O}$ & -19.8567 \\
\hline Analcime & -1.3734 & Lime & -20.6368 \\
\hline Boehmite & -1.4977 & Ca5Si6017^ $21 / 2 \mathrm{H} 2$ & -20.9138 \\
\hline Clinochl-7A & -1.5614 & Rankinite & -21.2945 \\
\hline Prehnite & -1.7381 & $\mathrm{MnCl} 2^{\wedge} \mathrm{H} 2 \mathrm{O}$ & -21.4972 \\
\hline Albite high & -1.9378 & Ca5Si6017^11/2H & -23.0862 \\
\hline Enstatite & -2.1025 & Hydrophilite & -23.2644 \\
\hline Gypsum & -2.1519 & Carnallite & -23.4036 \\
\hline Fluorite & -2.2288 & $\mathrm{MgCl}^{\wedge}{ }^{\wedge} 2 \mathrm{H} 2 \mathrm{O}$ & -24.1762 \\
\hline Diopside & -2.2771 & $\mathrm{Na} 3 \mathrm{H}(\mathrm{SO} 4) 2$ & -24.2706 \\
\hline Anhydrite & -2.4226 & $\mathrm{Ca} 2 \mathrm{Cl} 2(\mathrm{OH}) 2^{\wedge} \mathrm{H} 2 \mathrm{O}$ & -24.6508 \\
\hline Rhodochrosite & -2.4252 & $\mathrm{Ca} 4 \mathrm{Si} 3010^{\wedge} 3 / 2 \mathrm{H} 2 \mathrm{O}$ & -24.8654 \\
\hline Huntite & -2.4621 & Scacchite & -24.8663 \\
\hline Dawsonite & -2.6258 & Merwinite & -24.8998 \\
\hline Kalsilite & -2.7665 & $\mathrm{Ca} 5 \mathrm{Si} 6017^{\wedge} 3 \mathrm{H} 2 \mathrm{O}$ & -27.0506 \\
\hline Jadeite & -2.8086 & $\mathrm{MgCl}^{\wedge} \mathrm{H} 2 \mathrm{O}$ & -27.6845 \\
\hline Bassanite & -3.0540 & $\mathrm{Ca} 3 \mathrm{Si} 2 \mathrm{O}^{\wedge} ` 3 \mathrm{H} 2 \mathrm{O}$ & -29.6476 \\
\hline $\mathrm{Mn}(\mathrm{OH}) 3(\mathrm{C})$ & -3.1706 & Burkeite & -31.5446 \\
\hline $\mathrm{CaSO}^{\wedge} 1 / 2 \mathrm{H} 2 \mathrm{O}$ (bet & -3.2344 & $\mathrm{KMgCl}^{\wedge} 2 \mathrm{H} 2 \mathrm{O}$ & -33.5648 \\
\hline Wairakite & -3.3324 & Chloromagnesite & -33.6678 \\
\hline Nesquehonite & -3.3668 & Ca6Si6018^Н2O & -37.7169 \\
\hline Kyanite & -3.5302 & $\mathrm{Ca} 4 \mathrm{Cl} 2(\mathrm{OH}) 6^{\wedge} 13 \mathrm{H} 2$ & -40.0655 \\
\hline Brucite & -3.6795 & Ca3Sio5 & -40.5581 \\
\hline Margarite & -3.8096 & $\mathrm{KMgCl} 3$ & -41.1906 \\
\hline Andalusite & -3.8299 & Al2 (SO4) $3^{\wedge} 6 \mathrm{H} 20$ & -45.0866 \\
\hline $\mathrm{CaSi} 2 \mathrm{O}^{\wedge} 2 \mathrm{H} 2 \mathrm{O}$ & -4.0093 & Tachyhydrite & -50.4305 \\
\hline Sillimanite & -4.2075 & $\mathrm{Na} 4 \mathrm{SiO} 4$ & -53.0881 \\
\hline Clinozoisite & -4.3885 & $\mathrm{~K} 8 \mathrm{H} 4(\mathrm{CO} 3) 6^{\wedge} 3 \mathrm{H} 2 \mathrm{O}$ & -61.6640 \\
\hline Zoisite & -4.4354 & Al2 (SO4) 3 & -63.4383 \\
\hline Wollastonite & -4.4443 & Graphite & -77.7269 \\
\hline Epsomite & -4.5050 & $\mathrm{Na6Si2O}$ & -83.4210 \\
\hline Hexahydrite & -4.8120 & Misenite & -95.0248 \\
\hline Pseudowollastoni & -4.8574 & Sulfur-Rhmb & -111.1877 \\
\hline Artinite & -4.9131 & Alabandite & -147.3430 \\
\hline Nepheline & -4.9524 & O-phth acid(c) & -613.1751 \\
\hline Gases & fugacity & $\log$ fug. & \\
\hline \multicolumn{4}{|c|}{ 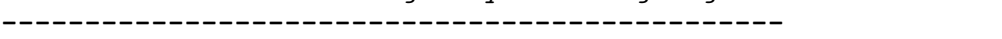 } \\
\hline $\mathrm{O} 2(\mathrm{~g})$ & 0.2000 & -0.699 & \\
\hline Steam & 0.01739 & -1.760 & \\
\hline $\mathrm{CO} 2(\mathrm{~g})$ & 0.0005389 & -3.268 & \\
\hline $\mathrm{H} 2(\mathrm{~g})$ & $1.410 e-043$ & -42.851 & \\
\hline H2S ( g ) & $8.576 e-149$ & -148.067 & \\
\hline $\mathrm{CH} 4(\mathrm{~g})$ & $4.844 e-151$ & $-150 \cdot 315$ & \\
\hline $\mathrm{S} 2(\mathrm{~g})$ & $9.702 e-238$ & -237.013 & \\
\hline
\end{tabular}




\begin{tabular}{|c|c|c|c|}
\hline \multirow[b]{2}{*}{ Original basis } & \multirow[b]{2}{*}{ total moles } & \multicolumn{2}{|c|}{ In fluid } \\
\hline & & moles & $\mathrm{mg} / \mathrm{kg}$ \\
\hline & & (1) & \\
\hline $\mathrm{Al}+++$ & $6.30 e-007$ & $6.30 e-007$ & 0.0170 \\
\hline $\mathrm{Ca}++$ & 0.000886 & 0.000886 & 35.5 \\
\hline $\mathrm{Cl}-$ & 0.000144 & 0.000144 & 5.10 \\
\hline $\mathrm{F}-$ & $1.05 e-005$ & $1.05 e-005$ & 0.200 \\
\hline $\mathrm{H}+$ & $-9.34 e-006$ & $-9.34 e-006$ & -0.00941 \\
\hline $\mathrm{H} 2 \mathrm{O}$ & 55.5 & 55.5 & $1.00 \mathrm{e}+006$ \\
\hline $\mathrm{HCO} 3-$ & 0.00168 & 0.00168 & 103 . \\
\hline $\mathrm{K}+$ & $4.86 e-005$ & $4.86 e-005$ & 1.90 \\
\hline $\mathrm{Mg}++$ & 0.00146 & 0.00146 & 35.4 \\
\hline $\mathrm{Mn}++$ & $2.00 e-008$ & $2.00 e-008$ & 0.00110 \\
\hline $\mathrm{Na}+$ & 0.000339 & 0.000339 & 7.80 \\
\hline 02 ( aq) & 0.000307 & 0.000307 & 9.83 \\
\hline SO4-- & 0.000708 & 0.000708 & 68.0 \\
\hline Sio2 (aq) & 0.000288 & 0.000288 & 17.3 \\
\hline
\end{tabular}

\begin{tabular}{lrrr} 
Elemental composition & \multicolumn{2}{c}{ In fluid } \\
total moles & moles & $\mathrm{mg} / \mathrm{kg}$ \\
\hline Aluminum & $6.301 \mathrm{e}-007$ & $6.301 \mathrm{e}-007$ & 0.01700 \\
Calcium & 0.0008857 & 0.0008857 & 35.49 \\
Carbon & 0.001683 & 0.001683 & 20.21 \\
Chlorine & 0.0001439 & 0.0001439 & 5.099 \\
Fluorine & $1.053 e-005$ & $1.053 e-005$ & 0.1999 \\
Hydrogen & 111.0 & 111.0 & $1.119 \mathrm{e}+005$ \\
Magnesium & 0.001456 & 0.001456 & 35.39 \\
Manganese & $2.002 \mathrm{e}-008$ & $2.002 \mathrm{e}-008$ & 0.001100 \\
Oxygen & 55.52 & 55.52 & $8.880 \mathrm{e}+005$ \\
Potassium & $4.860 \mathrm{e}-005$ & $4.860 \mathrm{e}-005$ & 1.899 \\
Silicon & 0.0002879 & 0.0002879 & 8.084 \\
Sodium & 0.0003393 & 0.0003393 & 7.798 \\
Sulfur & 0.0007079 & 0.0007079 & 22.69
\end{tabular}

\section{A1.3 Sample 04JC3}

$\begin{array}{lll}\text { Temperature }=14.2 \mathrm{C} & \begin{array}{l}\text { Pressure }=1.013 \text { bars } \\ \text { log fo2 }=-0.699\end{array} \\ \mathrm{pH}=8.200 & & \begin{array}{l}\text { pe }=13.2223 \\ \text { Eh }=0.7538 \text { volts }\end{array} \\ \text { Ionic strength } & =.006399 \\ \text { Activity of water } & = & 0.999995 \\ \text { Solvent mass } & = & 1.000000 \mathrm{~kg} \\ \text { Solution mass } & = & 1.000273 \mathrm{~kg} \\ \text { Solution density } & = & 1.020 \mathrm{~g} / \mathrm{cm} 3 \\ \text { Chlorinity } & = & 0.000144 \mathrm{molal} \\ \text { Dissolved solids } & = & 274 \mathrm{mg} / \mathrm{kg} \mathrm{sol} \mathrm{n} \\ \text { Rock mass } & = & 0.00000 \mathrm{~kg} \\ \text { Carbonate alkalinity }= & 58.39 \mathrm{mg} / \mathrm{kg} \mathrm{as} \mathrm{CaCO3}\end{array}$

No minerals in system.

\begin{tabular}{|c|c|c|c|c|}
\hline Aqueous species & molality & $\mathrm{mg} / \mathrm{kg}$ sol'n & act. coef. & $\log$ act. \\
\hline $\mathrm{Mg}++$ & 0.001620 & 39.36 & 0.7379 & -2.9226 \\
\hline $\mathrm{HCO} 3-$ & 0.001126 & 68.69 & 0.9214 & -2.9840 \\
\hline SO4-- & 0.0008353 & 80.21 & 0.7169 & -3.2227 \\
\hline SiO2 (aq) & 0.0004436 & 26.64 & 1.0017 & -3.3523 \\
\hline $\mathrm{Ca}++$ & 0.0003364 & 13.48 & 0.7278 & -3.6112 \\
\hline $\mathrm{O} 2$ ( aq) & 0.0003158 & 10.10 & 1.0017 & -3.4999 \\
\hline $\mathrm{Na}+$ & 0.0002425 & 5.573 & 0.9205 & -3.6513 \\
\hline $\mathrm{Cl}-$ & 0.0001433 & 5.081 & 0.9186 & -3.8805 \\
\hline $\mathrm{MgSO} 4$ & 0.0001135 & 13.66 & 1.0000 & -3.9450 \\
\hline $\mathrm{K}+$ & $4.585 e-005$ & 1.792 & 0.9186 & -4.3755 \\
\hline $\mathrm{CaSO} 4$ & $2.887 e-005$ & 3.929 & 1.0000 & -4.5396 \\
\hline $\mathrm{CO} 2(\mathrm{aq})$ & $1.808 e-005$ & 0.7955 & 1.0000 & -4.7428 \\
\hline $\mathrm{MgHCO} 3+$ & $1.328 e-005$ & 1.133 & 0.9205 & -4.9128 \\
\hline $\mathrm{F}-$ & $9.875 e-006$ & 0.1876 & 0.9196 & -5.0419 \\
\hline H3SiO4- & $8.415 e-006$ & 0.8001 & 0.9205 & -5.1109 \\
\hline $\mathrm{CO} 3--$ & $8.105 e-006$ & 0.4863 & 0.7197 & -5.2341 \\
\hline $\mathrm{MgCO} 3$ & $4.544 e-006$ & 0.3830 & 1.0000 & -5.3425 \\
\hline CaHCO3+ & $4.219 e-006$ & 0.4265 & 0.9226 & -5.4097 \\
\hline $\mathrm{CaCO} 3$ & $1.996 e-006$ & 0.1997 & 1.0000 & -5.6998 \\
\hline $\mathrm{Fe}(\mathrm{OH}) 3$ & $1.900 e-006$ & 0.2030 & 1.0000 & -5.7212 \\
\hline $\mathrm{Al}(\mathrm{OH}) 4-$ & $7.369 e-007$ & 0.07000 & 0.9205 & -6.1686 \\
\hline
\end{tabular}




\begin{tabular}{|c|c|c|c|c|}
\hline $\mathrm{OH}-$ & $7.323 e-007$ & 0.01245 & 0.9196 & -6.1718 \\
\hline $\mathrm{Mn++}$ & $6.820 e-007$ & 0.03746 & 0.7278 & -6.3042 \\
\hline NaSO4- & $6.769 e-007$ & 0.08057 & 0.9205 & -6.2054 \\
\hline $\mathrm{MgF}+$ & $6.271 e-007$ & 0.02715 & 0.9205 & -6.2387 \\
\hline MgH3SiO4+ & $4.673 e-007$ & 0.05578 & 0.9205 & -6.3664 \\
\hline $\mathrm{NaHCO} 3$ & $3.874 \mathrm{e}-007$ & 0.03253 & 1.0000 & -6.4119 \\
\hline $\mathrm{MgCl}+$ & $2.864 e-007$ & 0.01711 & 0.9205 & -6.5790 \\
\hline $\mathrm{CaCl}+$ & $2.223 e-007$ & 0.01679 & 0.9205 & -6.6891 \\
\hline KSO4- & $1.887 e-007$ & 0.02549 & 0.9205 & -6.7603 \\
\hline $\mathrm{MgH} 2 \mathrm{SiO} 4$ & $1.405 e-007$ & 0.01663 & 1.0000 & -6.8523 \\
\hline $\mathrm{MgOH}+$ & $1.218 e-007$ & 0.005032 & 0.9205 & -6.9502 \\
\hline $\mathrm{MnO} 4-$ & $6.640 e-008$ & 0.007895 & 0.9205 & -7.2138 \\
\hline СaH3SiO4+ & $5.437 e-008$ & 0.007349 & 0.9205 & -7.3006 \\
\hline $\mathrm{Fe}(\mathrm{OH}) 4-$ & $5.283 e-008$ & 0.006543 & 0.9205 & -7.3131 \\
\hline $\mathrm{Fe}(\mathrm{OH}) 2+$ & $5.226 e-008$ & 0.004695 & 0.9205 & -7.3178 \\
\hline $\mathrm{MnSO} 4$ & $4.742 e-008$ & 0.007159 & 1.0000 & -7.3240 \\
\hline $\mathrm{Mg} 2 \mathrm{CO} 3++$ & $3.235 e-008$ & 0.003513 & 0.7225 & -7.6313 \\
\hline $\mathrm{NaH} 3 \mathrm{SiO} 4$ & $2.517 e-008$ & 0.002972 & 1.0000 & -7.5991 \\
\hline $\mathrm{CaF}+$ & $2.507 e-008$ & 0.001481 & 0.9205 & -7.6368 \\
\hline $\mathrm{Mg}(\mathrm{H} 3 \mathrm{SiO} 4) 2$ & $1.717 e-008$ & 0.003682 & 1.0000 & -7.7652 \\
\hline $\mathrm{MnCO} 3$ & $1.220 e-008$ & 0.001402 & 1.0000 & -7.9137 \\
\hline $\mathrm{Al}(\mathrm{OH}) 3$ & $1.156 e-008$ & 0.0009011 & 1.0000 & -7.9372 \\
\hline $\mathrm{MnHCO} 3+$ & $9.965 e-009$ & 0.001155 & 0.9205 & -8.0375 \\
\hline $\mathrm{H}+$ & $6.795 e-009$ & $6.846 e-006$ & 0.9286 & -8.2000 \\
\hline $\mathrm{NaCO} 3-$ & $5.973 e-009$ & 0.0004956 & 0.9205 & -8.2598 \\
\hline $\mathrm{CaOH}+$ & $3.263 e-009$ & 0.0001862 & 0.9205 & -8.5224 \\
\hline $\mathrm{CaH} 2 \mathrm{SiO} 4$ & $2.428 \mathrm{e}-009$ & 0.0003257 & 1.0000 & -8.6147 \\
\hline $\mathrm{MnOH}+$ & $9.479 \mathrm{e}-010$ & $6.818 e-005$ & 0.9205 & -9.0592 \\
\hline $\mathrm{NaCl}$ & $5.784 e-010$ & $3.380 e-005$ & 1.0000 & -9.2377 \\
\hline $\mathrm{Ca}(\mathrm{H} 3 \mathrm{SiO} 4) 2$ & $4.159 e-010$ & $9.575 e-005$ & 1.0000 & -9.3810 \\
\hline HSO 4- & $2.960 e-010$ & $2.872 e-005$ & 0.9205 & -9.5647 \\
\hline $\mathrm{NaF}$ & $2.246 e-010$ & $9.428 e-006$ & 1.0000 & -9.6486 \\
\hline $\mathrm{Al}(\mathrm{OH}) 2+$ & $1.579 e-010$ & $9.629 e-006$ & 0.9205 & -9.8376 \\
\hline $\mathrm{KCl}$ & $1.220 e-010$ & $9.092 \mathrm{e}-006$ & 1.0000 & -9.9137 \\
\hline $\mathrm{NaOH}$ & $9.405 e-011$ & $3.761 e-006$ & 1.0000 & -10.0266 \\
\hline $\mathrm{MnF}+$ & $8.892 \mathrm{e}-011$ & $6.572 \mathrm{e}-006$ & 0.9205 & -10.0870 \\
\hline $\mathrm{HF}$ & $6.977 e-011$ & $1.395 e-006$ & 1.0000 & -10.1563 \\
\hline H2SiO4-- & $6.417 e-011$ & $6.036 e-006$ & 0.7169 & -10.3372 \\
\hline H6 (H2SiO4) 4-- & $5.025 e-011$ & $1.921 e-005$ & 0.7169 & -10.4434 \\
\hline $\mathrm{MnO} 4--$ & $5.000 e-011$ & $5.945 e-006$ & 0.7169 & -10.4456 \\
\hline $\mathrm{MnCl}+$ & $4.502 e-011$ & $4.068 e-006$ & 0.9205 & -10.3826 \\
\hline $\mathrm{KOH}$ & $8.526 e-012$ & $4.782 e-007$ & 1.0000 & -11.0693 \\
\hline $\mathrm{Mg} 2 \mathrm{OH}+++$ & $7.557 e-012$ & $4.957 e-007$ & 0.5043 & -11.4189 \\
\hline $\mathrm{FeOH}++$ & $1.948 \mathrm{e}-012$ & $1.419 \mathrm{e}-007$ & 0.7225 & -11.8515 \\
\hline $\mathrm{Mn} 2(\mathrm{OH}) 3+$ & $1.356 \mathrm{e}-012$ & $2.181 e-007$ & 0.9205 & -11.9037 \\
\hline
\end{tabular}

Mineral saturation states

$\log Q / K$

$\log Q / K$

$\begin{array}{llll} & & & \\ \text { Birnessite } & 58.2938 \mathrm{~s} / \mathrm{sat} & \text { Analc-dehydr } & -5.8496 \\ \text { Todorokite } & 50.6131 \mathrm{~s} / \mathrm{sat} & \text { Forsterite } & -5.9196 \\ \text { Nontronit-Mg } & 18.2118 \mathrm{~s} / \mathrm{sat} & \text { Kieserite } & -6.3570 \\ \text { Nontronit-Ca } & 18.1005 \mathrm{~s} / \mathrm{sat} & \text { Jarosite-K } & -6.7304 \\ \text { Nontronit-K } & 17.6028 \mathrm{~s} / \mathrm{sat} & \text { Tephroite } & -7.2840 \\ \text { Nontronit-Na } & 17.4746 \mathrm{~s} / \mathrm{sat} & \text { Kalicinite } & -7.3083 \\ \text { Hematite } & 13.1507 \mathrm{~s} / \mathrm{sat} & \text { Monticellite } & -8.1438 \\ \text { Antigorite } & 13.0965 \mathrm{~s} / \mathrm{sat} & \text { Ca2Si308^5/2H20 } & -8.4207 \\ \text { Bixbyite } & 10.8535 \mathrm{~s} / \mathrm{sat} & \text { Grossular } & -8.5218 \\ \text { Pyrolusite } & 9.8310 \mathrm{~s} / \mathrm{sat} & \text { Manganosite } & -8.5978 \\ \text { Hausmannite } & 9.3172 \mathrm{~s} / \mathrm{sat} & \text { Jarosite-Na } & -8.6492 \\ \text { Clinoptil-K } & 7.5771 \mathrm{~s} / \mathrm{sat} & \text { Cordier^hydr } & -8.9081 \\ \text { Andradite } & 7.4990 \mathrm{~s} / \mathrm{sat} & \text { Mirabilite } & -8.9310 \\ \text { Clinoptil-Ca } & 6.5202 \mathrm{~s} / \mathrm{sat} & \text { Halite } & -9.0922 \\ \text { Goethite } & 6.1137 \mathrm{~s} / \mathrm{sat} & \text { Sylvite } & -9.0938 \\ \text { Manganite } & 5.2820 \mathrm{~s} / \mathrm{sat} & \text { MHSH(Mg1.5) } & -9.3724 \\ \text { Saponite-Mg } & 5.1045 \mathrm{~s} / \mathrm{sat} & \text { Spinel } & -9.3817 \\ \text { Saponite-Ca } & 4.9920 \mathrm{~s} / \mathrm{sat} & \text { NaFeO2(c) } & -9.3912 \\ \text { Epidote-ord } & 4.8981 \mathrm{~s} / \mathrm{sat} & \text { Cronstedt-7A } & -9.5226 \\ \text { Epidote } & 4.8973 \mathrm{~s} / \mathrm{sat} & \text { Arcanite } & -10.1051 \\ \text { Muscovite } & 4.8126 \mathrm{~s} / \mathrm{sat} & \text { Thenardite } & -10.2868 \\ \text { Smectite-Reykjan } & 4.8103 \mathrm{~s} / \mathrm{sat} & \text { Alunite } & -10.3168 \\ \text { Ferrite-Mg } & 4.5581 \mathrm{~s} / \mathrm{sat} & \text { Portlandite } & -10.6406 \\ \text { Saponite-K } & 4.4906 \mathrm{~s} / \mathrm{sat} & \text { Ca(OH)2(c) } & -10.6406 \\ \text { Phengite } & 4.4746 \mathrm{~s} / \mathrm{sat} & \text { Hydromagnesite } & -10.8067 \\ \text { Talc } & 4.4247 \mathrm{~s} / \mathrm{sat} & \text { Gaylussite } & -10.9453 \\ \text { Saponite-Na } & 4.3660 \mathrm{~s} / \mathrm{sat} & \text { Ca-Al Pyroxene } & -11.2503 \\ & & & \end{array}$




\begin{tabular}{|c|c|c|c|}
\hline Heulandite & $3.9570 \mathrm{~s} / \mathrm{sat}$ & Cordier^anhy & -11.5035 \\
\hline Saponite-H & $3.8940 \mathrm{~s} / \mathrm{sat}$ & Pirssonite & -11.5176 \\
\hline Illite & $3.8427 \mathrm{~s} / \mathrm{sat}$ & $\mathrm{Mg} 2 \mathrm{Cl}(\mathrm{OH}) 3^{\wedge} 4 \mathrm{H} 2 \mathrm{O}$ & -11.6888 \\
\hline Mordenite-K & $3.7889 \mathrm{~s} / \mathrm{sat}$ & $\mathrm{MgSO}_{4}$ (c) & -11.7441 \\
\hline Beidellit-Mg & $3.6490 \mathrm{~s} / \mathrm{sat}$ & $\mathrm{KNaCO} 3^{\wedge} 6 \mathrm{H} 2 \mathrm{O}$ & -12.2054 \\
\hline Beidellit-Ca & $3.5379 \mathrm{~s} / \mathrm{sat}$ & Ferrosilite & -12.3918 \\
\hline Ferrite-Ca & $3.5362 \mathrm{~s} / \mathrm{sat}$ & Siderite & -12.3978 \\
\hline Beidellit-K & $3.0365 \mathrm{~s} / \mathrm{sat}$ & $\mathrm{MnSO} 4$ (c) & -12.5997 \\
\hline Kaolinite & $3.0053 \mathrm{~s} / \mathrm{sat}$ & $\mathrm{FeO}(\mathrm{C})$ & -13.2100 \\
\hline Pyrophyllite & $2.9772 \mathrm{~s} / \mathrm{sat}$ & Wustite & -13.3453 \\
\hline Phlogopite & $2.9669 \mathrm{~s} / \mathrm{sat}$ & FeF3 (c) & -13.4530 \\
\hline Beidellit-Na & $2.9118 \mathrm{~s} / \mathrm{sat}$ & Mercallite & -14.1186 \\
\hline Clinochl-14A & $2.8361 \mathrm{~s} / \mathrm{sat}$ & Kainite & -14.3514 \\
\hline Clinoptil-Mg & $2.6232 \mathrm{~s} / \mathrm{sat}$ & Bloedite & -14.4072 \\
\hline Maximum Microcli & $2.5755 \mathrm{~s} / \mathrm{sat}$ & $\mathrm{Fe}(\mathrm{OH}) 2(\mathrm{ppd})$ & -14.6720 \\
\hline K-feldspar & $2.5740 \mathrm{~s} / \mathrm{sat}$ & Akermanite & -14.7548 \\
\hline Beidellit-H & $2.4371 \mathrm{~s} / \mathrm{sat}$ & Hercynite & -14.7870 \\
\hline Laumontite & $2.1390 \mathrm{~s} / \mathrm{sat}$ & Bischofite & -15.3153 \\
\hline Tremolite & $1.7011 \mathrm{~s} / \mathrm{sat}$ & Hedenbergite & -15.4225 \\
\hline Sepiolite & $1.6657 \mathrm{~s} / \mathrm{sat}$ & $\mathrm{MgOHCl}$ & -15.4316 \\
\hline Clinoptil-Na & $1.6261 \mathrm{~s} / \mathrm{sat}$ & Antarcticite & -15.4391 \\
\hline $\mathrm{Fe}(\mathrm{OH}) 3(\mathrm{ppd})$ & $1.6032 \mathrm{~s} / \mathrm{sat}$ & $\mathrm{Ca} 2 \mathrm{SiO}_{4}{ }^{\wedge} 7 / 6 \mathrm{H} 2 \mathrm{O}$ & -16.0369 \\
\hline Paragonite & $1.4115 \mathrm{~s} / \mathrm{sat}$ & $\mathrm{Na2Si205}$ & -16.1416 \\
\hline Sanidine high & $1.3027 \mathrm{~s} / \mathrm{sat}$ & $\mathrm{CaCl} 12^{\wedge} 4 \mathrm{H} 2 \mathrm{O}$ & -16.3228 \\
\hline Magnetite & $1.0956 \mathrm{~s} / \mathrm{sat}$ & $\mathrm{K} 2 \mathrm{CO}^{\wedge} 3 / 2 \mathrm{H} 2 \mathrm{O}$ & -16.7187 \\
\hline Dolomite & $1.0060 \mathrm{~s} / \mathrm{sat}$ & Ca2SiO4 (gamma) & -16.7445 \\
\hline Dolomite-ord & $1.0060 \mathrm{~s} / \mathrm{sat}$ & $\mathrm{MnCl} 2 \wedge 4 \mathrm{H} 2 \mathrm{O}$ & -16.8446 \\
\hline Amesite-14A & $0.9715 \mathrm{~s} / \mathrm{sat}$ & $\mathrm{Na} 2 \mathrm{SiO} 3$ & -17.0961 \\
\hline Quartz & $0.8534 \mathrm{~s} / \mathrm{sat}$ & Pargasite & -17.9522 \\
\hline Smectite-low-Fe- & $0.8257 \mathrm{~s} / \mathrm{sat}$ & $\mathrm{MnCl} 22^{\wedge} 2 \mathrm{H} 2 \mathrm{O}$ & -18.2617 \\
\hline Mordenite-Na & $0.8104 \mathrm{~s} / \mathrm{sat}$ & Larnite & -18.2750 \\
\hline Chrysotile & $0.7053 \mathrm{~s} / \mathrm{sat}$ & Melanterite & -18.3904 \\
\hline Tridymite & $0.6772 \mathrm{~s} / \mathrm{sat}$ & $\mathrm{MgCl} 2 \wedge 4 \mathrm{H} 2 \mathrm{O}$ & -18.4251 \\
\hline Chalcedony & $0.5719 \mathrm{~s} / \mathrm{sat}$ & Gehlenite & -19.4900 \\
\hline Gibbsite & $0.4425 \mathrm{~s} / \mathrm{sat}$ & Ripidolit-14A & -19.6910 \\
\hline Cristobalite & $0.2777 \mathrm{~s} / \mathrm{sat}$ & $\mathrm{CaCl2} 22^{\mathrm{H}} 2 \mathrm{O}$ & -19.7559 \\
\hline Albite low & $0.0991 \mathrm{~s} / \mathrm{sat}$ & $\mathrm{MnCl} 2^{\wedge} \mathrm{H} 2 \mathrm{O}$ & -19.9160 \\
\hline Albite & $0.0990 \mathrm{~s} / \mathrm{sat}$ & $\mathrm{CaCl} 2^{\wedge} \mathrm{H} 2 \mathrm{O}$ & -19.9414 \\
\hline Lawsonite & -0.0770 & Ferrite-2-Ca & -20.3039 \\
\hline Calcite & -0.2607 & Lime & -21.1880 \\
\hline Aragonite & -0.4267 & Ca5Si6O17^21/2H & -21.8593 \\
\hline Magnesite & -0.4303 & Rankinite & -22.3140 \\
\hline Diaspore & -0.4459 & Ripidolit-7A & -23.1574 \\
\hline Amrph^silica & -0.5228 & Scacchite & -23.3036 \\
\hline Dolomite-dis & -0.6198 & Carnallite & -23.3372 \\
\hline Clinochl-7A & -0.6274 & Chamosite-7A & -23.4651 \\
\hline Analcime & -0.9429 & Hydrophilite & -23.7107 \\
\hline Rhodochrosite & -0.9737 & FeSO 4 (c) & -23.9541 \\
\hline Monohydrocalcite & -1.2336 & Ca5Si6017^11/2H 2 & -24.0795 \\
\hline Albite high & -1.2927 & $\mathrm{MgCl} 22^{\wedge} 2 \mathrm{H} 2 \mathrm{O}$ & -24.1752 \\
\hline Boehmite & -1.3484 & $\mathrm{Na} 3 \mathrm{H}(\mathrm{SO} 4) 2$ & -24.3285 \\
\hline $\operatorname{Mn}(\mathrm{OH}) 3(\mathrm{C})$ & -1.6001 & $\mathrm{Ca} 2 \mathrm{Cl} 2(\mathrm{OH}) 2^{\wedge} \mathrm{H} 2 \mathrm{O}$ & -25.4860 \\
\hline Prehnite & -1.6683 & FeF2 (c) & -25.5968 \\
\hline Smectite-high-Fe & -1.8754 & Fayalite & -25.8808 \\
\hline Enstatite & -1.9046 & Merwinite & -25.9530 \\
\hline Diopside & -2.3098 & $\mathrm{Ca} 4 \mathrm{Si} 3 \mathrm{O} 10^{\wedge} 3 / 2 \mathrm{H} 2 \mathrm{O}$ & -26.1170 \\
\hline Jadeite & -2.3769 & $\mathrm{MgCl} 22^{\wedge} \mathrm{H} 2 \mathrm{O}$ & -27.7071 \\
\hline Gypsum & -2.3777 & Ca5Si6O17^3H 20 & -28.0818 \\
\hline Kalsilite & -2.4303 & Ca3Si2O7^3H2O & -30.6810 \\
\hline Fluorite & -2.5940 & Minnesotaite & -31.7289 \\
\hline Wairakite & -2.6229 & Burkeite & -32.1658 \\
\hline Anhydrite & -2.6625 & Annite & -32.3253 \\
\hline Dawsonite & -2.7295 & $\mathrm{KMgCl} 3^{\wedge} 2 \mathrm{H} 2 \mathrm{O}$ & -33.5708 \\
\hline Kyanite & -3.0176 & Chloromagnesite & -33.7248 \\
\hline Margarite & -3.2180 & Greenalite & -34.0894 \\
\hline Bassanite & -3.2943 & Lawrencite & -34.9789 \\
\hline Andalusite & -3.3210 & Ca6Si6018^H2O & -39.2749 \\
\hline Huntite & -3.3691 & $\mathrm{KMgCl} 3$ & -41.2452 \\
\hline Rhodonite & -3.4216 & $\mathrm{Ca} 4 \mathrm{Cl} 2(\mathrm{OH}) 6^{\wedge} 13 \mathrm{H} 2$ & -41.6202 \\
\hline $\mathrm{CaSO} 4^{\wedge} 1 / 2 \mathrm{H} 2 \mathrm{O}$ (bet & -3.4766 & Ca3Sio5 & -41.8912 \\
\hline Nesquehonite & -3.4951 & Molysite & -43.6771 \\
\hline Anthophyllite & -3.5697 & $\mathrm{Al2}(\mathrm{SO} 4) 3^{\wedge} 6 \mathrm{H} 2 \mathrm{O}$ & -44.2784 \\
\hline Brucite & -3.7015 & $\mathrm{Fe} 2(\mathrm{SO} 4) 3(\mathrm{C})$ & -47.1812 \\
\hline Sillimanite & -3.7015 & Tachyhydrite & -50.7194 \\
\hline $\mathrm{CaSi} 2 \mathrm{O5}^{\wedge} 2 \mathrm{H} 2 \mathrm{O}$ & -4.0174 & $\mathrm{Na} 4 \mathrm{SiO} 4$ & -53.7351 \\
\hline Clinozoisite & -4.1863 & Daphnite-14A & -54.2443 \\
\hline
\end{tabular}




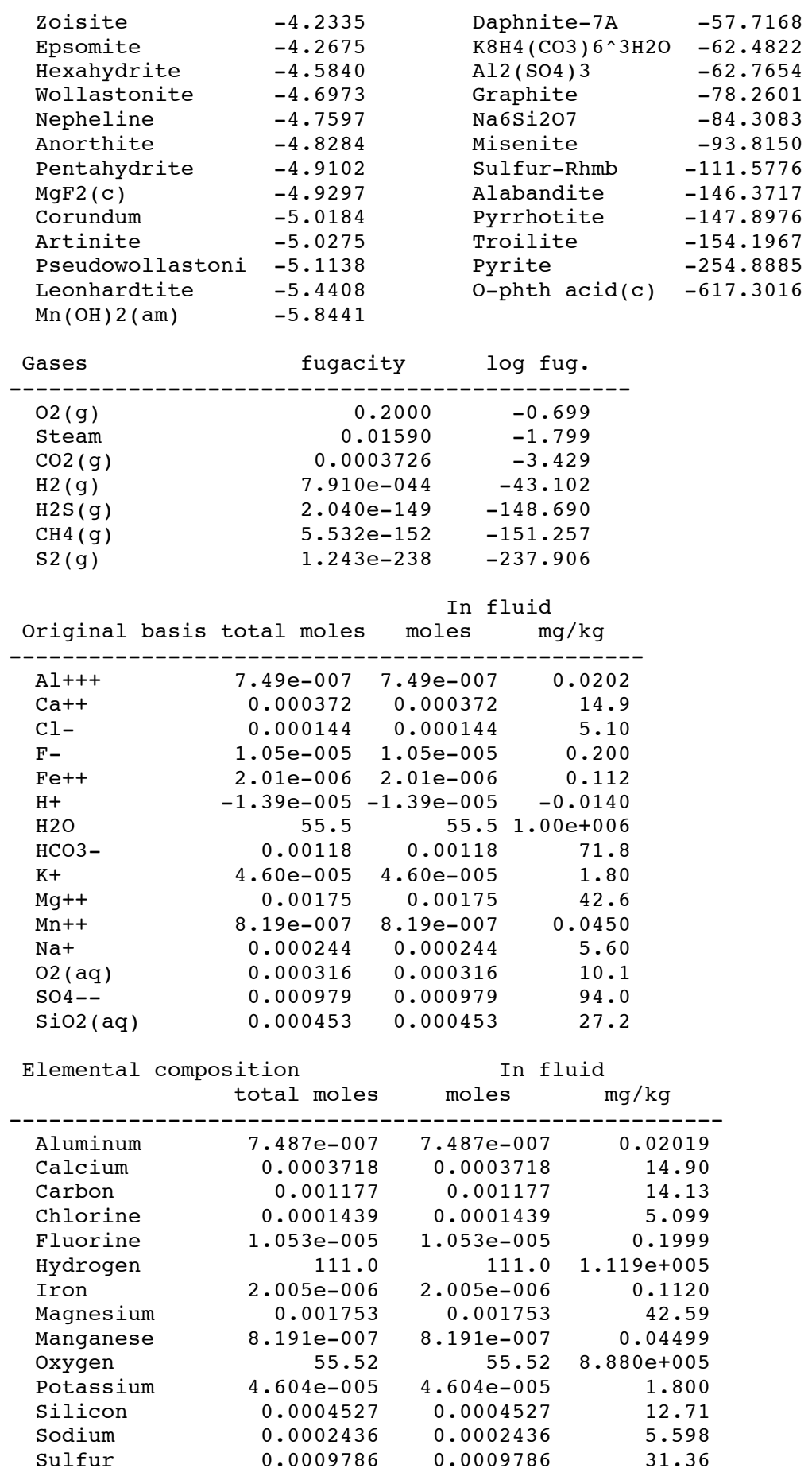

\section{A1.3 Sample 04OHE1}

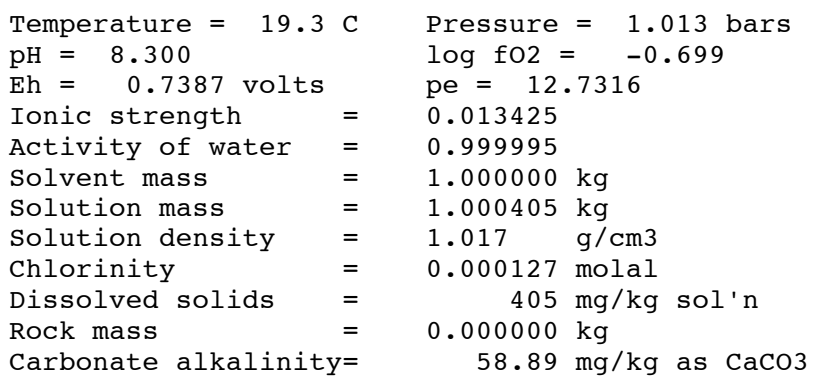


No minerals in system.

\begin{tabular}{|c|c|c|c|c|}
\hline Aqueous species & molality & $\mathrm{mg} / \mathrm{kg}$ sol'n & act. coef. & $\log$ act. \\
\hline $\mathrm{Mg}++$ & 0.004155 & 100.9 & 0.6631 & -2.5599 \\
\hline $\mathrm{HCO} 3-$ & 0.001086 & 66.23 & 0.8926 & -3.0135 \\
\hline $\mathrm{Ca}++$ & 0.001075 & 43.05 & 0.6464 & -3.1583 \\
\hline SO4-- & 0.0009844 & 94.52 & 0.6280 & -3.2088 \\
\hline $\mathrm{Na}+$ & 0.0005976 & 13.73 & 0.8909 & -3.2737 \\
\hline $\mathrm{O} 2$ ( aq) & 0.0002867 & 9.169 & 1.0035 & -3.5411 \\
\hline $\mathrm{MgSO} 4$ & 0.0002793 & 33.60 & 1.0000 & -3.5539 \\
\hline SiO2 (aq) & 0.0002671 & 16.04 & 1.0035 & -3.5718 \\
\hline $\mathrm{Cl}-$ & 0.0001259 & 4.462 & 0.8874 & -3.9519 \\
\hline CaSO4 & $8.762 e-005$ & 11.92 & 1.0000 & -4.0574 \\
\hline $\mathrm{K}+$ & $6.367 e-005$ & 2.488 & 0.8874 & -4.2480 \\
\hline $\mathrm{MgHCO} 3+$ & $3.011 e-005$ & 2.568 & 0.8909 & -4.5715 \\
\hline $\mathrm{MgCO} 3$ & $1.530 e-005$ & 1.290 & 1.0000 & -4.8152 \\
\hline $\mathrm{F}-$ & $1.354 e-005$ & 0.2571 & 0.8892 & -4.9195 \\
\hline $\mathrm{CO} 2(\mathrm{aq})$ & $1.253 e-005$ & 0.5514 & 1.0000 & -4.9019 \\
\hline $\mathrm{CO} 3--$ & $1.205 e-005$ & 0.7228 & 0.6328 & -5.1178 \\
\hline СaHCO3+ & $1.176 e-005$ & 1.188 & 0.8949 & -4.9780 \\
\hline $\mathrm{CaCO} 3$ & $7.976 e-006$ & 0.7980 & 1.0000 & -5.0982 \\
\hline H3SiO4- & $7.778 e-006$ & 0.7395 & 0.8909 & -5.1593 \\
\hline $\mathrm{MgF}+$ & $2.146 e-006$ & 0.09287 & 0.8909 & -5.7186 \\
\hline NaSO4- & $1.767 e-006$ & 0.2103 & 0.8909 & -5.8029 \\
\hline $\mathrm{OH}-$ & $1.450 e-006$ & 0.02465 & 0.8892 & -5.8896 \\
\hline $\mathrm{MgH} 3 \mathrm{SiO} 4+$ & $8.453 e-007$ & 0.1009 & 0.8909 & -6.1232 \\
\hline $\mathrm{NaHCO} 3$ & $7.814 e-007$ & 0.06562 & 1.0000 & -6.1071 \\
\hline $\mathrm{MgOH}+$ & $5.898 e-007$ & 0.02436 & 0.8909 & -6.2794 \\
\hline $\mathrm{MgCl}+$ & $5.323 e-007$ & 0.03179 & 0.8909 & -6.3240 \\
\hline $\mathrm{Al}(\mathrm{OH}) 4-$ & $5.180 e-007$ & 0.04920 & 0.8909 & -6.3358 \\
\hline $\mathrm{CaCl}+$ & $4.937 e-007$ & 0.03728 & 0.8909 & -6.3567 \\
\hline MgH2SiO4 & $3.097 e-007$ & 0.03666 & 1.0000 & -6.5091 \\
\hline KSO4- & $2.736 e-007$ & 0.03697 & 0.8909 & -6.6130 \\
\hline $\mathrm{Mg} 2 \mathrm{CO} 3++$ & $2.605 e-007$ & 0.02828 & 0.6374 & -6.7797 \\
\hline СaH3SiO4+ & $1.211 e-007$ & 0.01636 & 0.8909 & -6.9672 \\
\hline $\mathrm{CaF}+$ & $1.070 e-007$ & 0.006319 & 0.8909 & -7.0208 \\
\hline NaH3SiO4 & $5.303 e-008$ & 0.006261 & 1.0000 & -7.2754 \\
\hline $\mathrm{Mn}++$ & $2.796 e-008$ & 0.001535 & 0.6464 & -7.7430 \\
\hline $\operatorname{Mg}(\mathrm{H} 3 \mathrm{SiO} 4) 2$ & $2.283 e-008$ & 0.004896 & 1.0000 & -7.6414 \\
\hline $\mathrm{CaOH}+$ & $1.917 e-008$ & 0.001094 & 0.8909 & -7.7676 \\
\hline $\mathrm{NaCO} 3-$ & $1.699 e-008$ & 0.001409 & 0.8909 & -7.8201 \\
\hline $\mathrm{MnO} 4-$ & $1.098 e-008$ & 0.001306 & 0.8909 & -8.0094 \\
\hline СаH2SiO4 & $6.588 e-009$ & 0.0008836 & 1.0000 & -8.1813 \\
\hline $\mathrm{H}+$ & $5.534 e-009$ & $5.575 e-006$ & 0.9057 & -8.3000 \\
\hline $\mathrm{Al}(\mathrm{OH}) 3$ & $4.511 e-009$ & 0.0003517 & 1.0000 & -8.3458 \\
\hline MnSO4 & $1.956 e-009$ & 0.0002952 & 1.0000 & -8.7086 \\
\hline $\mathrm{NaCl}$ & $1.315 e-009$ & $7.685 e-005$ & 1.0000 & -8.8809 \\
\hline $\mathrm{NaF}$ & $7.741 e-010$ & $3.249 e-005$ & 1.0000 & -9.1112 \\
\hline $\mathrm{Ca}(\mathrm{H} 3 \mathrm{SiO} 4) 2$ & $6.807 e-010$ & 0.0001567 & 1.0000 & -9.1670 \\
\hline $\mathrm{MnCO} 3$ & $5.223 e-010$ & $6.002 e-005$ & 1.0000 & -9.2820 \\
\hline $\mathrm{NaOH}$ & $4.325 e-010$ & $1.729 e-005$ & 1.0000 & -9.3640 \\
\hline $\mathrm{MnHCO} 3+$ & $3.578 e-010$ & $4.147 e-005$ & 0.8909 & -9.4966 \\
\hline HSO4- & $2.873 e-010$ & $2.787 e-005$ & 0.8909 & -9.5919 \\
\hline $\mathrm{KCl}$ & $1.500 e-010$ & $1.118 e-005$ & 1.0000 & -9.8239 \\
\hline H2SiO4-- & $1.181 e-010$ & $1.110 e-005$ & 0.6280 & -10.1299 \\
\hline $\mathrm{Mg} 2 \mathrm{OH}+++$ & $1.003 e-010$ & $6.582 e-006$ & 0.3962 & -10.4006 \\
\hline $\mathrm{HF}$ & $8.037 e-011$ & $1.607 e-006$ & 1.0000 & -10.0949 \\
\hline $\mathrm{MnOH}+$ & $6.726 e-011$ & $4.837 e-006$ & 0.8909 & -10.2224 \\
\hline $\mathrm{Al}(\mathrm{OH}) 2+$ & $3.325 e-011$ & $2.027 e-006$ & 0.8909 & -10.5284 \\
\hline $\mathrm{KOH}$ & $2.245 e-011$ & $1.259 e-006$ & 1.0000 & -10.6488 \\
\hline $\mathrm{MnO} 4--$ & $1.444 e-011$ & $1.717 e-006$ & 0.6280 & -11.0424 \\
\hline H6 (H2SiO4) 4-- & $1.204 e-011$ & $4.604 e-006$ & 0.6280 & -11.1212 \\
\hline $\mathrm{MnF}+$ & $4.856 e-012$ & $3.589 e-007$ & 0.8909 & -11.3639 \\
\hline $\mathrm{MnCl}+$ & $1.437 e-012$ & $1.298 e-007$ & 0.8909 & -11.8928 \\
\hline \multirow[t]{2}{*}{ Mineral saturation } & \multicolumn{4}{|l|}{ states } \\
\hline & \multicolumn{2}{|l|}{$\log \mathrm{Q} / \mathrm{K}$} & \multicolumn{2}{|l|}{$\log \mathrm{Q} / \mathrm{K}$} \\
\hline \multicolumn{5}{|c|}{ 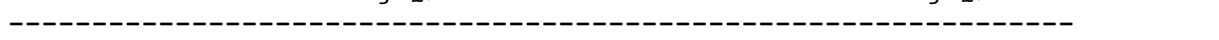 } \\
\hline Birnessite & $48.3835 \mathrm{~s} / \mathrm{sat}$ & Clinozoisite & -4.8469 & \\
\hline Todorokite & $41.9416 \mathrm{~s} / \mathrm{sat}$ & Zoisite & -4.8929 & \\
\hline Antigorite & $28.3814 \mathrm{~s} / \mathrm{sat}$ & Nepheline & -4.9896 & \\
\hline Pyrolusite & $8.5484 \mathrm{~s} / \mathrm{sat}$ & Leonhardtite & -4.9943 & \\
\hline Bixbyite & $8.5443 \mathrm{~s} / \mathrm{sat}$ & Sillimanite & -5.0083 & \\
\hline Saponite-Mg & $6.4792 \mathrm{~s} / \mathrm{sat}$ & Margarite & -5.0382 & \\
\hline
\end{tabular}




\begin{tabular}{|c|c|c|c|}
\hline Saponite-Ca & $6.3723 \mathrm{~s} / \mathrm{sat}$ & Anorthite & -5.4923 \\
\hline Hausmannite & $6.0132 \mathrm{~s} / \mathrm{sat}$ & Kieserite & -5.8259 \\
\hline Saponite-K & $5.8020 \mathrm{~s} / \mathrm{sat}$ & Corundum & -6.0066 \\
\hline Saponite-Na & $5.7760 \mathrm{~s} / \mathrm{sat}$ & Analc-dehydr & -6.3516 \\
\hline Talc & $5.7453 \mathrm{~s} / \mathrm{sat}$ & Monticellite & -6.5198 \\
\hline Tremolite & $5.4209 \mathrm{~s} / \mathrm{sat}$ & $\mathrm{Mn}(\mathrm{OH}) 2(\mathrm{am})$ & -6.7729 \\
\hline Saponite-H & $5.1434 \mathrm{~s} / \mathrm{sat}$ & Kalicinite & -7.3944 \\
\hline Clinochl-14A & $5.1122 \mathrm{~s} / \mathrm{sat}$ & $\mathrm{Ca} 2 \mathrm{Si} 3 \mathrm{O}^{\wedge} 5 / 2 \mathrm{H} 2 \mathrm{O}$ & -7.4720 \\
\hline Phlogopite & $4.3124 \mathrm{~s} / \mathrm{sat}$ & Hydromagnesite & -7.6040 \\
\hline Manganite & $4.0432 \mathrm{~s} / \mathrm{sat}$ & Grossular & -7.6900 \\
\hline Clinoptil-K & $3.8441 \mathrm{~s} / \mathrm{sat}$ & MHSH (Mg1.5) & -8.3319 \\
\hline Phengite & $3.7381 \mathrm{~s} / \mathrm{sat}$ & Mirabilite & -8.3987 \\
\hline Clinoptil-Ca & $3.2031 \mathrm{~s} / \mathrm{sat}$ & Halite & -8.8021 \\
\hline Sepiolite & $3.1612 \mathrm{~s} / \mathrm{sat}$ & Sylvite & -9.0962 \\
\hline Chrysotile & $2.6668 \mathrm{~s} / \mathrm{sat}$ & Spinel & -9.4096 \\
\hline Muscovite & $2.4040 \mathrm{~s} / \mathrm{sat}$ & Tephroite & -9.4683 \\
\hline Dolomite & $2.1408 \mathrm{~s} / \mathrm{sat}$ & Manganosite & -9.4693 \\
\hline Dolomite-ord & $2.1408 \mathrm{~s} / \mathrm{sat}$ & Thenardite & -9.5199 \\
\hline Mordenite-K & $1.9218 \mathrm{~s} / \mathrm{sat}$ & Portlandite & -9.5808 \\
\hline Illite & $1.8010 \mathrm{~s} / \mathrm{sat}$ & $\mathrm{Ca}(\mathrm{OH}) 2(\mathrm{C})$ & -9.5808 \\
\hline Clinochl-7A & $1.6915 \mathrm{~s} / \mathrm{sat}$ & Arcanite & -9.9213 \\
\hline Amesite-14A & $1.6294 \mathrm{~s} / \mathrm{sat}$ & Gaylussite & -9.9600 \\
\hline Heulandite & $1.5835 \mathrm{~s} / \mathrm{sat}$ & Pirssonite & -10.3371 \\
\hline Beidellit-Mg & $1.3390 \mathrm{~s} / \mathrm{sat}$ & $\operatorname{Mg} 2 \mathrm{Cl}(\mathrm{OH}) 3^{\wedge} 4 \mathrm{H} 2 \mathrm{O}$ & -10.5120 \\
\hline Maximum Microcli & $1.3231 \mathrm{~s} / \mathrm{sat}$ & Cordier ${ }^{\wedge}$ hydr & -10.6076 \\
\hline K-feldspar & $1.3219 \mathrm{~s} / \mathrm{sat}$ & MgSO4 (c) & -11.0917 \\
\hline Beidellit-Ca & $1.2327 \mathrm{~s} / \mathrm{sat}$ & Ca-Al Pyroxene & -11.5188 \\
\hline Kaolinite & $1.2159 \mathrm{~s} / \mathrm{sat}$ & $\mathrm{KNaCO} 3^{\wedge} 6 \mathrm{H} 2 \mathrm{O}$ & -12.0719 \\
\hline Laumontite & $0.6825 \mathrm{~s} / \mathrm{sat}$ & Akermanite & -12.4016 \\
\hline Beidellit-K & $0.6625 \mathrm{~s} / \mathrm{sat}$ & Alunite & -12.5244 \\
\hline Beidellit-Na & $0.6364 \mathrm{~s} / \mathrm{sat}$ & Cordier^anhy & -13.1485 \\
\hline Pyrophyllite & $0.6092 \mathrm{~s} / \mathrm{sat}$ & Bloedite & -13.2616 \\
\hline Dolomite-dis & $0.5538 \mathrm{~s} / \mathrm{sat}$ & $\mathrm{MnSO} 4$ ( c ) & -13.8322 \\
\hline Quartz & $0.5388 \mathrm{~s} / \mathrm{sat}$ & Kainite & -13.8905 \\
\hline Tridymite & $0.3677 \mathrm{~s} / \mathrm{sat}$ & Mercallite & -14.2246 \\
\hline Calcite & $0.3359 \mathrm{~s} / \mathrm{sat}$ & $\mathrm{Ca} 2 \mathrm{SiO} 4^{\wedge} 7 / 6 \mathrm{H} 2 \mathrm{O}$ & -14.2986 \\
\hline Chalcedony & $0.2622 \mathrm{~s} / \mathrm{sat}$ & $\mathrm{MgOHCl}$ & -14.6681 \\
\hline Anthophyllite & $0.2228 \mathrm{~s} / \mathrm{sat}$ & Ca2SiO4 (gamma) & -14.9574 \\
\hline Aragonite & $0.1706 \mathrm{~s} / \mathrm{sat}$ & Bischofite & -15.0474 \\
\hline Magnesite & $0.1403 \mathrm{~s} / \mathrm{sat}$ & Antarcticite & -15.1517 \\
\hline Sanidine high & $0.0853 \mathrm{~s} / \mathrm{sat}$ & Pargasite & $-15 \cdot 1744$ \\
\hline Beidellit-H & -0.0001 & $\mathrm{Na} 2 \mathrm{Si} 205$ & -15.4413 \\
\hline Cristobalite & -0.0251 & $\mathrm{CaCl} 2^{\wedge} 4 \mathrm{H} 2 \mathrm{O}$ & -15.9855 \\
\hline Gibbsite & -0.1563 & Na2SiO3 & -16.0876 \\
\hline Clinoptil-Mg & -0.6369 & Larnite & -16.4549 \\
\hline Paragonite & -0.6449 & $\mathrm{~K} 2 \mathrm{CO}^{\wedge} 3 / 2 \mathrm{H} 2 \mathrm{O}$ & -16.5310 \\
\hline Monohydrocalcite & -0.6461 & $\mathrm{MgCl} 2^{\wedge} 4 \mathrm{H} 2 \mathrm{O}$ & -18.0707 \\
\hline Mordenite-Na & -0.7258 & $\mathrm{MnCl} 2^{\wedge} 4 \mathrm{H} 2 \mathrm{O}$ & -18.3937 \\
\hline Amrph^silica & -0.7950 & Gehlenite & -18.7037 \\
\hline Albite low & -0.8145 & $\mathrm{Ca} 5 \mathrm{Si} 6017^{\wedge} 21 / 2 \mathrm{H} 2$ & -19.1173 \\
\hline Albite & -0.8146 & $\mathrm{CaCl} 2^{\wedge} 2 \mathrm{H} 2 \mathrm{O}$ & -19.3096 \\
\hline Lawsonite & -0.9235 & $\mathrm{CaCl} 2^{\wedge} \mathrm{H} 2 \mathrm{O}$ & -19.4709 \\
\hline Diaspore & -0.9985 & $\mathrm{MnCl}^{\wedge} 2^{\wedge} \mathrm{H} 2 \mathrm{O}$ & -19.7396 \\
\hline Huntite & -1.0202 & Rankinite & -19.8234 \\
\hline Diopside & -1.0946 & Lime & -19.9232 \\
\hline Enstatite & -1.2897 & Ca5Si6017^11/2H & -21.1644 \\
\hline Clinoptil-Na & -1.4453 & $\mathrm{MnCl} 2^{\wedge} \mathrm{H} 2 \mathrm{O}$ & $-21 \cdot 3440$ \\
\hline Analcime & -1.5394 & Merwinite & -22.5034 \\
\hline Prehnite & -1.8648 & $\mathrm{Ca} 4 \mathrm{Si} 3 \mathrm{O} 10^{\wedge} 3 / 2 \mathrm{H} 2 \mathrm{O}$ & -23.0211 \\
\hline Boehmite & -1.8733 & Carnallite & -23.0913 \\
\hline Gypsum & -1.9160 & Hydrophilite & -23.1538 \\
\hline Fluorite & -1.9630 & $\mathrm{Na} 3 \mathrm{H}(\mathrm{SO} 4) 2$ & -23.4994 \\
\hline Anhydrite & -2.1497 & $\mathrm{MgCl}^{\wedge} 2 \mathrm{H}^{\prime} 2 \mathrm{O}$ & -23.6718 \\
\hline Albite high & -2.1716 & $\mathrm{Ca} 2 \mathrm{Cl} 2(\mathrm{OH}) 2^{\wedge} \mathrm{H} 2 \mathrm{O}$ & -24.2505 \\
\hline Rhodochrosite & -2.2809 & Scacchite & -24.6642 \\
\hline $\mathrm{Mn}(\mathrm{OH}) 3(\mathrm{C})$ & -2.6594 & $\mathrm{Ca} \mathrm{Si} 6 \mathrm{O} 17^{\wedge} 3 \mathrm{H} 2 \mathrm{O}$ & -25.0297 \\
\hline Bassanite & -2.7802 & $\mathrm{MgCl} 2^{\wedge} \mathrm{H} 2 \mathrm{O}$ & -27.1184 \\
\hline Brucite & -2.7850 & Ca3Si207^3Н 20 & -28.1410 \\
\hline Nesquehonite & -2.8798 & Burkeite & -30.1022 \\
\hline $\mathrm{CaSO}^{\wedge} 1 / 2 \mathrm{H} 2 \mathrm{O}$ (bet & -2.9560 & Chloromagnesite & -33.0120 \\
\hline Jadeite & -2.9771 & $\mathrm{KMgCl}^{\wedge} 2 \mathrm{H} 2 \mathrm{O}$ & -33.0636 \\
\hline Kalsilite & -2.9946 & $\mathrm{Ca} 6 \mathrm{Si} 6018^{\wedge} \mathrm{H} 20$ & -35.0458 \\
\hline Dawsonite & -3.0609 & Ca3Sio5 & -38.7615 \\
\hline Artinite & -3.6188 & $\mathrm{Ca} 4 \mathrm{Cl} 2(\mathrm{OH}) 6^{\wedge} 13 \mathrm{H} 2$ & -39.2404 \\
\hline $\mathrm{CaSi} 2 \mathrm{O}^{\wedge} 2 \mathrm{H} 2 \mathrm{O}$ & -3.7290 & $\mathrm{KMgCl} 3$ & -40.5627 \\
\hline Wairakite & -3.9127 & $\mathrm{Al} 2(\mathrm{SO} 4) 3^{\wedge} 6 \mathrm{H} 2 \mathrm{O}$ & -46.0578 \\
\hline
\end{tabular}




\begin{tabular}{|c|c|c|c|c|}
\hline Epsomite & -3.9196 & \multicolumn{2}{|c|}{ Tachyhydrite } & -49.7167 \\
\hline Wollastonite & -4.0165 & \multicolumn{2}{|c|}{$\mathrm{Na} 4 \mathrm{SiO} 4$} & -51.0701 \\
\hline Hexahydrite & -4.1994 & \multicolumn{2}{|c|}{$\mathrm{K} 8 \mathrm{H} 4(\mathrm{CO} 3) 6^{\wedge} 3 \mathrm{H} 2 \mathrm{O}$} & -62.4544 \\
\hline $\operatorname{MgF} 2(\mathrm{c})$ & -4.2728 & \multicolumn{2}{|c|}{$\mathrm{Al} 2(\mathrm{SO} 4) 3$} & -64.0564 \\
\hline Kyanite & -4.3481 & \multicolumn{2}{|c|}{ Graphite } & -77.0176 \\
\hline Forsterite & -4.3526 & \multicolumn{2}{|c|}{$\mathrm{Na} 6 \mathrm{Si} 207$} & -80.3655 \\
\hline Pseudowollastoni & -4.4209 & \multicolumn{2}{|c|}{ Misenite } & -94.4424 \\
\hline Pentahydrite & \multirow{2}{*}{$\begin{array}{l}-4.5336 \\
-4.6380\end{array}$} & \multicolumn{2}{|c|}{ Sulfur-Rhmb } & -109.8050 \\
\hline Andalusite & & \multicolumn{2}{|c|}{ Alabandite } & -144.9036 \\
\hline Rhodonite & -4.6672 & \multicolumn{2}{|c|}{ O-phth acid(c) } & -607.8719 \\
\hline Gases & fugacit & \multicolumn{2}{|c|}{$\log$ fug. } & \\
\hline -ー-ー-ー-ー-ー-ー & ------- & ------- & -- & \\
\hline $02(\mathrm{~g})$ & 0.2 & 2000 & 99 & \\
\hline Steam & 0.02 & 2195 & 59 & \\
\hline $\mathrm{CO} 2(\mathrm{~g})$ & 0.0002 & 2957 & 29 & \\
\hline $\mathrm{H} 2(\mathrm{~g})$ & $6.339 e-$ & -42.1 & 98 & \\
\hline $\mathrm{H} 2 \mathrm{~S}(\mathrm{~g})$ & $8.408 e-$ & -146.0 & 75 & \\
\hline $\mathrm{CH} 4(\mathrm{~g})$ & $2.870 \mathrm{e}-$ & $-148 \cdot 5$ & 42 & \\
\hline $\mathrm{S} 2(\mathrm{~g})$ & $1.110 \mathrm{e}-$ & -233.9 & 55 & \\
\hline Original basis to & otal moles & $\begin{array}{rr}\text { In } & \text { fluid } \\
\text { moles } & \mathrm{mg}\end{array}$ & $/ \mathrm{kg}$ & \\
\hline------------------ & -ー-ー-ー-ー-ー- & --ー-ー-ー-ー-ー-ー- & ------ & \\
\hline $\mathrm{Al}+++$ & $5.23 e-007$ & $5.23 e-007$ & .0141 & \\
\hline $\mathrm{Ca}++$ & 0.00118 & 0.00118 & 47.4 & \\
\hline $\mathrm{Cl}-$ & 0.000127 & 0.000127 & 4.50 & \\
\hline $\mathrm{F}-$ & $1.58 e-005$ & $1.58 e-005$ & 0.300 & \\
\hline $\mathrm{H}+$ & $3.67 e-005-3$ & $3.67 e-005$ & .0370 & \\
\hline $\mathrm{H} 2 \mathrm{O}$ & 55.5 & 55.51 .00 & $e+006$ & \\
\hline $\mathrm{HCO} 3-$ & 0.00118 & 0.00118 & 71.8 & \\
\hline $\mathrm{K}+$ & $6.39 e-005$ & $6.39 e-005$ & 2.50 & \\
\hline $\mathrm{Mg}++$ & 0.00448 & 0.00448 & 109 . & \\
\hline $\mathrm{Mn}++$ & $4.19 e-008$ & $4.19 e-008$ & 00230 & \\
\hline $\mathrm{Na}+$ & 0.000600 & 0.000600 & 13.8 & \\
\hline $\mathrm{O} 2$ ( aq) & 0.000287 & 0.000287 & 9.17 & \\
\hline $\mathrm{SO} 4--$ & 0.00135 & 0.00135 & 130 & \\
\hline SiO2 (aq) & 0.000276 & 0.000276 & 16.6 & \\
\hline Elemental composit & ition & In $\mathrm{fl}$ & uid & \\
\hline & total moles & moles & $\mathrm{mg} / \mathrm{kg}$ & \\
\hline --------- & -ー-ー-ー-ー-ー- & --ー-ー-ー-ー-ー-ー- & ------- & --- \\
\hline Aluminum & $5.226 e-007$ & $5.226 e-007$ & 0.014 & 409 \\
\hline Calcium & 0.001183 & 0.001183 & 47. & .38 \\
\hline Carbon & 0.001177 & 0.001177 & 14 . & .13 \\
\hline Chlorine & 0.0001269 & 0.0001269 & 4.4 & 498 \\
\hline Fluorine & $1.579 e-005$ & $1.579 e-005$ & 0.29 & 999 \\
\hline Hydrogen & 111.0 & 111.0 & $1.119 e+0$ & 005 \\
\hline Magnesium & 0.004485 & 0.004485 & 109 & 9.0 \\
\hline Manganese & $4.187 e-008$ & $4.187 e-008$ & 0.0022 & 299 \\
\hline Oxygen & 55.52 & 55.52 & $8.879 e+0$ & 005 \\
\hline Potassium & $6.394 e-005$ & $6.394 e-005$ & 2.4 & 499 \\
\hline Silicon & 0.0002763 & 0.0002763 & & 756 \\
\hline Sodium & 0.0006003 & 0.0006003 & 13. & .79 \\
\hline Sulfur & 0.001353 & 0.001353 & 43. & .37 \\
\hline
\end{tabular}

